San Jose State University

SJSU ScholarWorks

Master's Theses

Master's Theses and Graduate Research

Spring 2018

\title{
Evaluation of the Fragility of East Bay Municipal Utility District (EBMUD) Mokelumne Aqueduct
}

Sara Chalian

San Jose State University

Follow this and additional works at: https://scholarworks.sjsu.edu/etd_theses

\section{Recommended Citation}

Chalian, Sara, "Evaluation of the Fragility of East Bay Municipal Utility District (EBMUD) Mokelumne Aqueduct" (2018). Master's Theses. 4895.

DOI: https://doi.org/10.31979/etd.a7y5-fy24

https://scholarworks.sjsu.edu/etd_theses/4895

This Thesis is brought to you for free and open access by the Master's Theses and Graduate Research at SJSU ScholarWorks. It has been accepted for inclusion in Master's Theses by an authorized administrator of SJSU ScholarWorks. For more information, please contact scholarworks@sjsu.edu. 


\title{
EVALUATION OF THE FRAGILITY OF EAST BAY MUNICIPAL UTILITY DISTRICT (EBMUD) MOKELUMNE AQUEDUCT
}

\author{
A Thesis \\ Presented to \\ The Faculty of the Department of Civil and Environmental Engineering \\ San José State University \\ In Partial Fulfillment \\ of the Requirements for the Degree \\ Master of Science \\ by \\ Sara Chalian
}

May 2018 
(C) 2018

Sara Chalian

ALL RIGHTS RESERVED 
The Designated Thesis Committee Approves the Thesis Titled

\title{
EVALUATION OF THE FRAGILITY OF EAST BAY MUNICIPAL UTILITY DISTRICT (EBMUD) MOKELUMNE AQUEDUCT
}

\author{
by \\ Sara Chalian \\ APPROVED FOR THE DEPARTMENT OF \\ CIVIL AND ENVIRONMENTAL ENGINEERING
}

SAN JOSÉ STATE UNIVERSITY

May 2018

Laura Sullivan-Green, Ph.D. Civil and Environmental Engineering Department Manny Gabet, Ph.D. Geology Department

Yogesh Prashar, P.E., G.E. $\quad$ Associate Engineer, East Bay Municipal Utility District 


\begin{abstract}
EVALUATION OF THE FRAGILITY OF EAST BAY MUNICIPAL UTILITY DISTRICT (EBMUD) MOKELUMNE AQUEDUCT
\end{abstract}

by Sara Chalian

The East Bay Municipal Utility District provides water to the eastern region of the San Francisco Bay Area. Water is delivered through the Mokelumne Aqueduct, which consists of three large diameter steel pipelines. Approximately 15 miles of the aqueducts cross the fragile Sacramento-San Joaquin Delta. A stability analysis has been conducted to evaluate how resilient the elevated aqueduct is in the Delta. Subsidence in the Delta considerably reduces the lateral support of piles. Based on previous studies, and available survey and LiDAR data, the amount of subsidence in the Delta has been predicted over time. In addition, site-specific seismic studies have been considered in order to estimate strong ground motion parameters. A series of axial single pile analyses, lateral single pile analyses, and pile group analyses have been performed to quantify the impact of ground loss due to subsidence on pile capacities along the 15-mile alignment. Results were compared with both the maximum expected lateral load at the pile cap occurring due to seismic ground motion (base shear) and the lateral capacity at the 1-inch horizontal displacement of the pile cap (threshold). Analysis shows a significant reduction in the piles' lateral and axial capacities, caused by lack of soil shear strength. The analytical studies are presented and discussed in order to develop retrofit alternatives. 


\section{ACKNOWLEDGMENTS}

I would like to gratefully acknowledge the support of my committee members: Dr.

Laura Sullivan-Green, Civil and Environmental Engineering Department Chair; and Dr. Emmanuel Gabet, Geology Department Associate Professor.

I wish to acknowledge the help and guidance of my supervisor, Mr. Yogesh Prashar, EBMUD Associate Engineer. His experience and expertise were extremely valuable throughout my research.

Also, I would like to acknowledge my coworkers at EBMUD, Rachel Wong, Hon Fung Chan, and Lilian Leung, for their valuable contributions.

Finally, I would like to thank AECOM for their help during this study. 


\section{TABLE OF CONTENTS}

List of Tables........................................................................

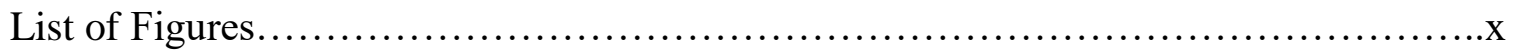

List of Abbreviations.................................................................iii

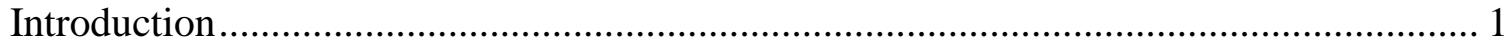

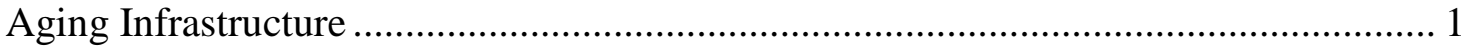

East Bay Municipal Utility District Challenge of Aging Water Infrastructure .............. 2

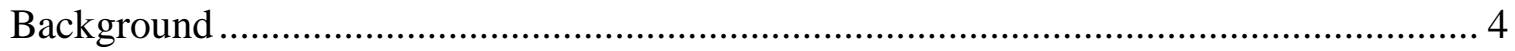

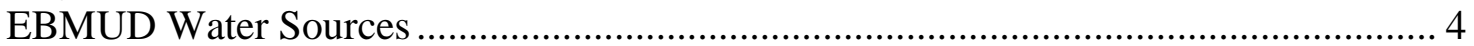

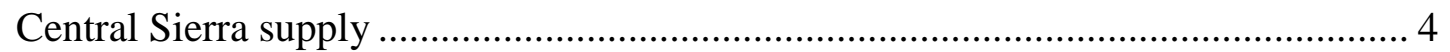

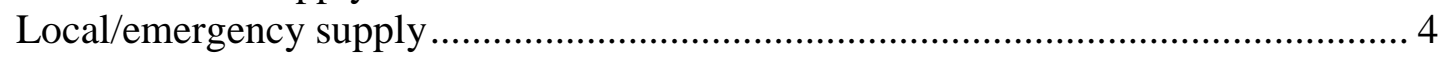

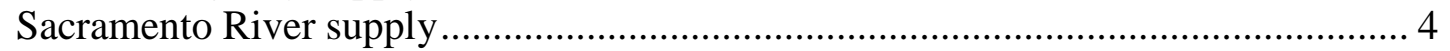

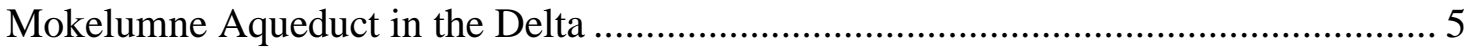

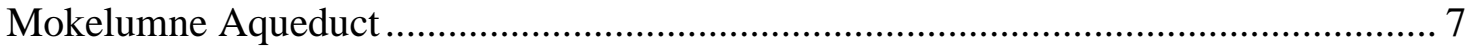

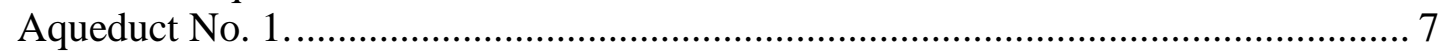

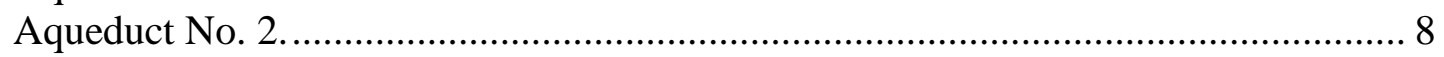

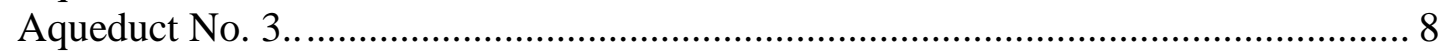

Sacramento-San Joaquin Delta.......................................................................... 9

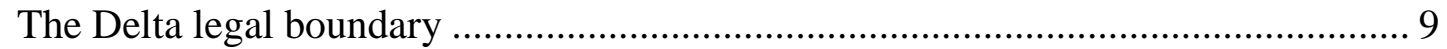

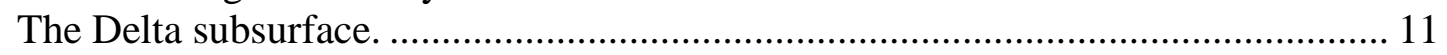

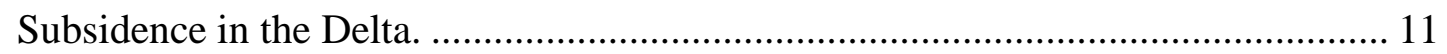

EBMUD Evaluation of Hazard to Mokelumne Aqueduct in the Delta.......................... 14

EBMUD Strategy for Protecting Mokelumne Aqueduct in the Delta ......................... 15

Short-term protection alternative..................................................................... 15

Long-term protection alternative......................................................................... 17

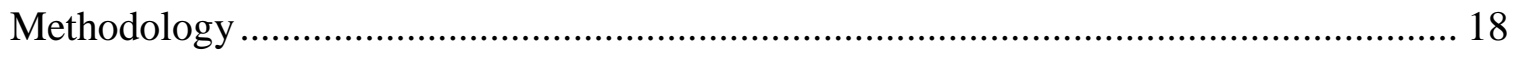

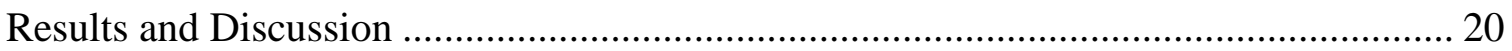

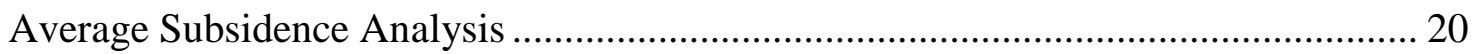

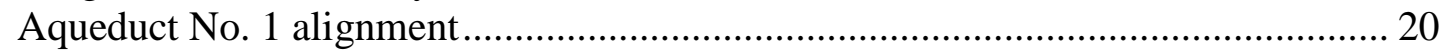

Aqueduct No. 3 alignment ........................................................................... 24

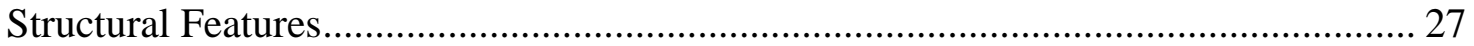

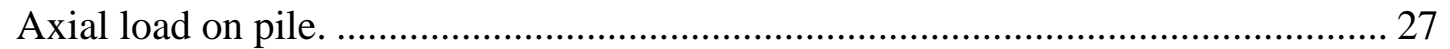

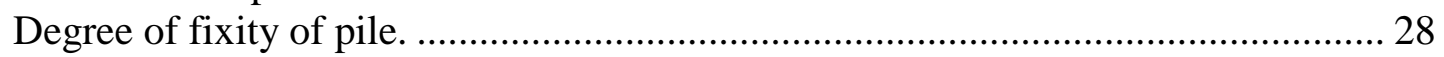

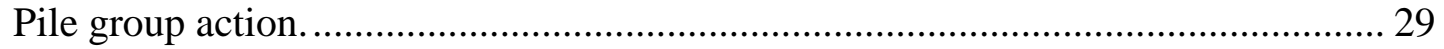

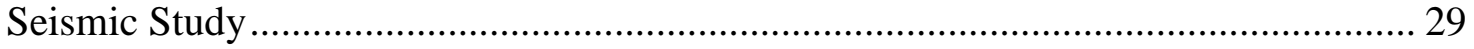

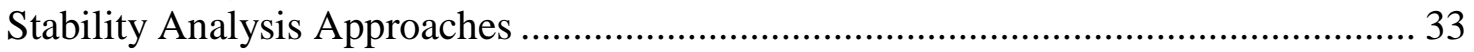




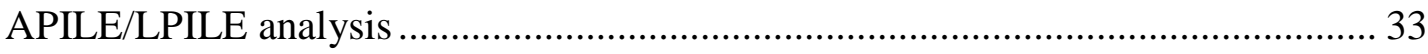

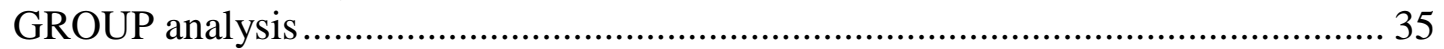

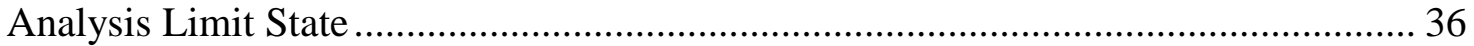

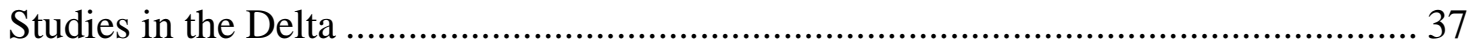

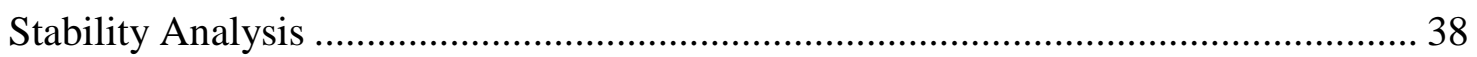

Region 3: Old River to Middle River. .................................................................. 38

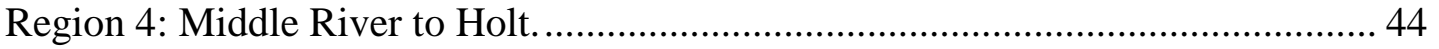

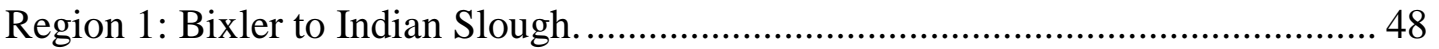

Region 2: Indian Slough to Old River. ......................................................... 51

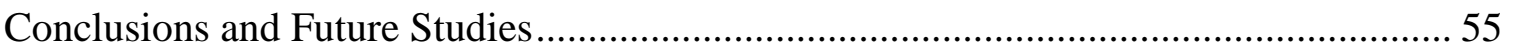

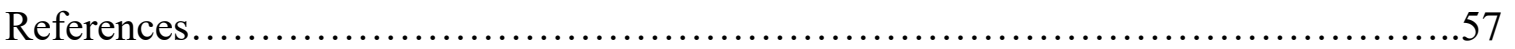

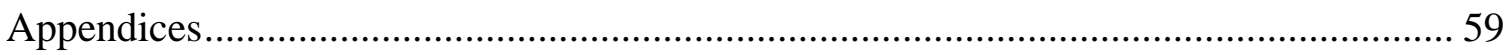

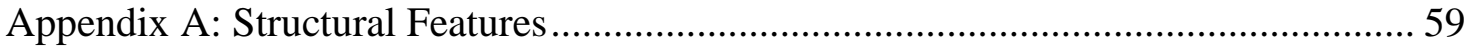

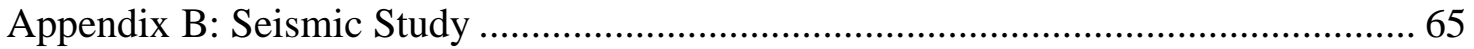

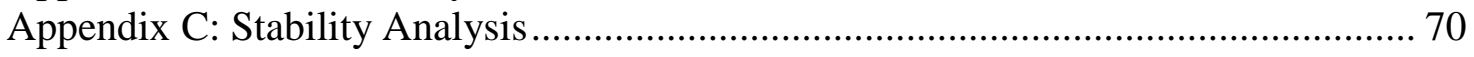




\section{LIST OF TABLES}

Table 1. Summary of Hazards and Associated Probabilities (Qualitative) ................... 15

Table 2. Axial Load on Each Vertical and Battered Pile ........................................... 28

Table 3. Degree of Fixity of Pile at Pile Cap .......................................................... 28

Table 4. PGA from Two Seismic Studies (475-Year Return Period) ........................... 31

Table 5. PGA from Two Seismic Studies (2475-Year Return Period) ........................ 31

Table 6. PGA and Base Shear at Four Regions in the Delta..................................... 32

Table 7. Regions Corresponding to Each Area of Evaluation .................................... 38

Table 8. The 1999 Study by EBMUD’s Consultant: Soil Profile A2 (Old River to

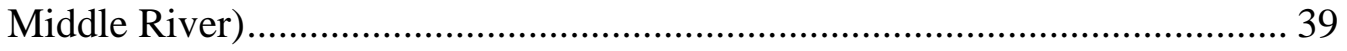

Table 9. AECOM Study: Boring Log DT-B6A-2016 (Old River to Middle River) ...... 39

Table 10. The 1999 Study by EBMUD's Consultant: Soil Profile A2 (Middle River to

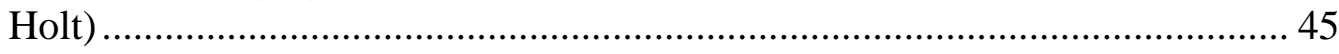

Table 11. AECOM Study: Boring Log DT-B13-2016 (Middle River to Holt) ................ 45

Table 12. The 1999 Study by EBMUD's Consultant: Soil Profile A1 (Bixler to Indian

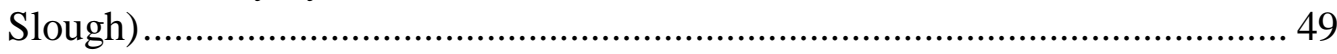

Table 13. AECOM Study: Boring Log DT-B1-2016 (Bixler to Indian Slough) ............. 49

Table 14. The 1999 Study by EBMUD’s Consultant: Soil Profile A1 (Indian Slough to Old River) .................................................................................... 52

Table 15. AECOM Study: Boring Log DT-B4-2016 (Indian Slough to Old River) ........ 52

Table A1. Pre-tensioned Pre-stressed Concrete Pile Properties......................62

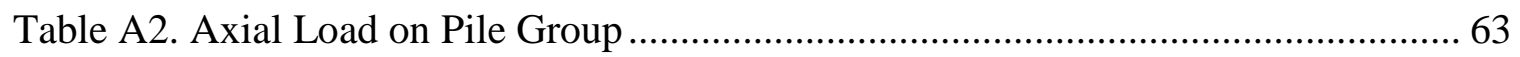

Table A3. Development Length for Deformed Bars and Deformed Wires in Tension .... 64

Table A4. Parameters to Calculate Development Length for Bars ................................ 64 
Table B1. References and Parameters for Determination of Base Shear.

Table C1. The 1999 Study by EBMUD's Consultant: Ultimate Axial and Uplift Capacities Assumption................................................ 71

Table C2. Fines Correction for Estimation of Residual Undrained Strength.............81

Table C3. Parameters to Determine Corrected SPT N-Value.........................82 


\section{LIST OF FIGURES}

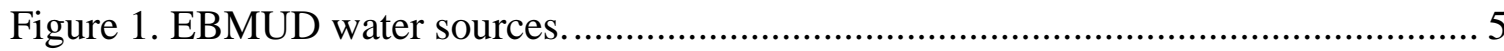

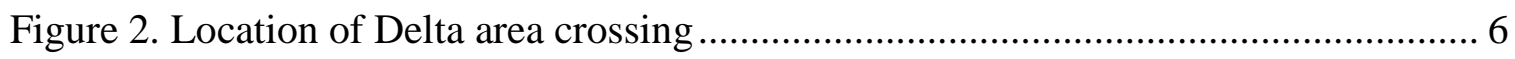

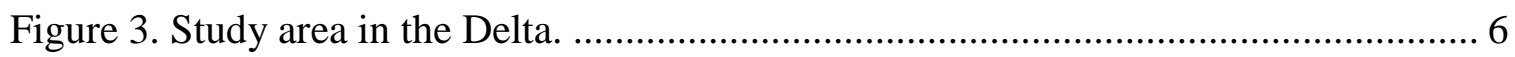

Figure 4. Mokelumne Aqueduct ......................................................................... 9

Figure 5. The Delta legal boundary …………………............................................. 10

Figure 6. Estimated land surface elevation changes from 1998 to 2050 ......................... 13

Figure 7. Aqueduct No. 3 seismic upgrade …………….......................................... 16

Figure 8. Aqueduct No. 1 LiDAR data 2007..................................................................... 21

Figure 9. Average subsidence along Aqueduct No. 1 from 1966 to 2007 ........................ 22

Figure 10. Overall view of Aqueduct No. 1 in the Delta ............................................... 23

Figure 11. Aqueduct No. 3 LiDAR data 2007 ................................................................. 24

Figure 12. Average subsidence along the Aqueduct No. 3 from 2007 to 2015 ................ 25

Figure 13. Overall view of Aqueduct No. 3 in the Delta ............................................... 26

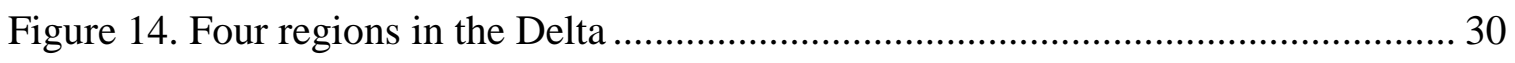

Figure 15. Variation of PGA along the Delta aqueducts .................................................. 32

Figure 16. APILE/LPILE analysis approach ............................................................. 34

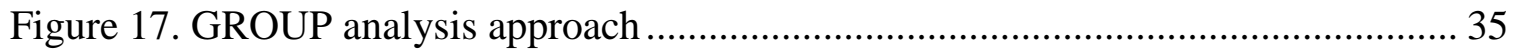

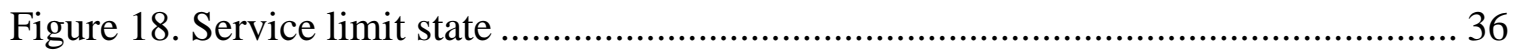

Figure 19. The 1999 study by EBMUD's consultant: Region 3, ultimate lateral capacity

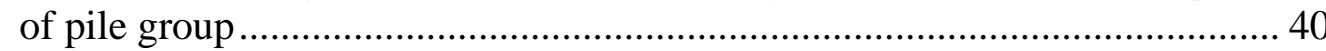

Figure 20. Region 3, comparison between the 1999 study by EBMUD's consultant and APILE/LPILE and GROUP analyses 
Figure 21. Region 3, matching the ultimate lateral capacity from the APILE/LPILE analysis with the 1999 study by EBMUD's consultant

Figure 22. Region 3, matching the ultimate axial/uplift capacity assumptions in the 1999 study by EBMUD's consultant with the APILE/LPILE analysis . 43

Figure 23. Region 4, evaluation of subsidence impact (APILE/LPILE analysis) ........... 46

Figure 24. Region 4, evaluation of subsidence impact (GROUP analysis) .................... 46

Figure 25. Region 4, APILE/LPILE and GROUP analyses (present condition) .............. 47

Figure 26. Region 1, evaluation of liquefiable subsurface impact (APILE/LPILE and GROUP analyses) ........................................................................ 51

Figure 27. Region 2, evaluation of liquefiable subsurface impact (APILE/LPILE and

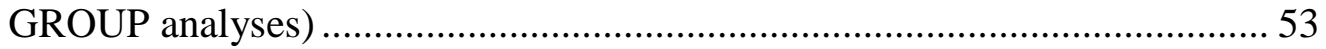

Figure A1. Aqueduct No. 3 pile caps for elevated pipe .......................................... 60

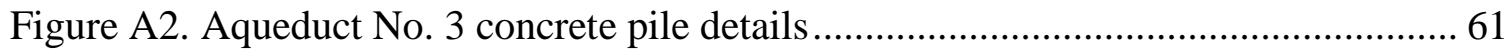

Figure B1. Selected boring logs for PGA determination...........................66

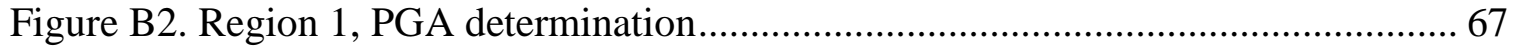

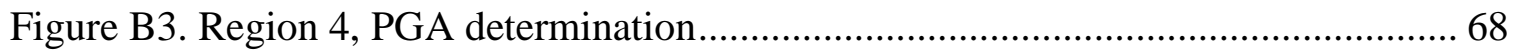

Figure C1. Proposed exploration plan....................................... 72

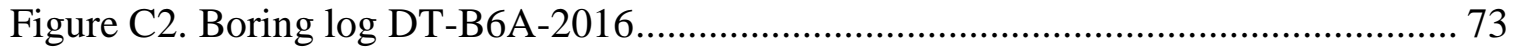

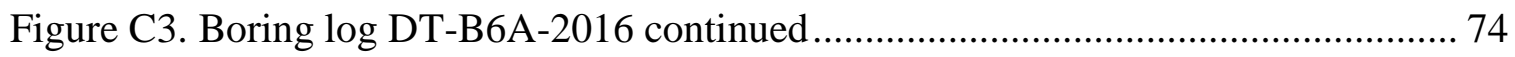

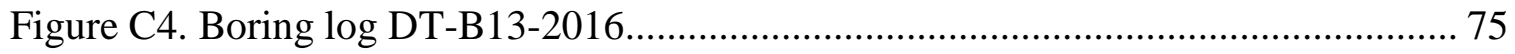

Figure C5. Boring log DT-B13-2016 continued.................................................. 76

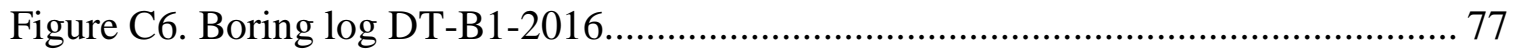

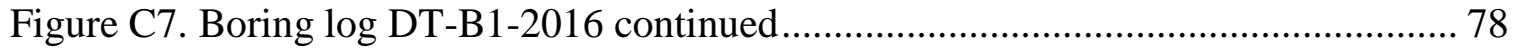

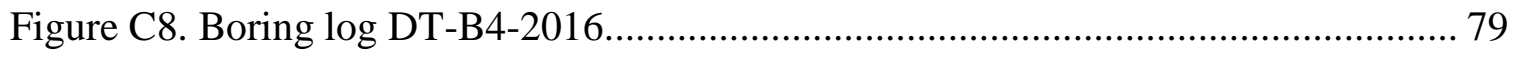




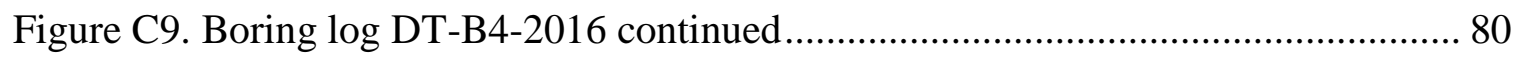

Figure C10. Relationship between residual strength and corrected SPT resistance ......... 81 


\section{LIST OF ABBREVIATIONS}

ACI - American Concrete Institute

ASCE - American Society of Civil Engineers

ASTM - American Society for Testing and Materials

CPT - Cone Penetration Testing

DL - Dead Load

DRMS - Delta Risk Management Strategy

DWR - Department of Water Resources

EBMUD - East Bay Municipal Utility District

FEMA - Federal Emergency Management Agency

GDR - Geotechnical Data Report

GIS - Geographic Information System

GSE - Ground Surface Elevation

LiDAR - Light Detection and Ranging

PGA - Peak Ground Acceleration

Spec - Specifications

USGS - United States Geological Survey 


\section{Introduction}

\section{Aging Infrastructure}

America's aging infrastructure is currently a highlighted topic in the media. The problem is extensive, affecting transportation systems, water supplies, communication networks, and the energy grid. Every four years, the American Society of Civil Engineers (ASCE) Committee on America's Infrastructure provides a broad assessment of 16 major infrastructure categories in ASCE's Infrastructure Report Card. The Report Card studies current infrastructure conditions, estimates the investment needed in each infrastructure category, and makes recommendations to improve them (American Society of Civil Engineers, 2017).

Infrastructure is not only the foundation of a society's economy and quality of life; it is also critical to the public's health and wellbeing. The infrastructure's condition has a huge impact on the economy, business productivity, employment, and personal income in a nation. Therefore, it is not wise to defer investment in our nation's critical infrastructure systems. This investment must be consistently and wisely allocated. Smart investment will be possible with leadership, planning, and a clear vision.

California faces its own infrastructure challenges. According to the ASCE California Infrastructure Report Card (American Society of Civil Engineers, 2017), “Driving on roads in need of repair in California costs each driver $\$ 844$ per year, and 5.5\% of bridges are rated structurally deficient. Drinking water needs in California are an estimated $\$ 44.5$ billion, and wastewater needs total $\$ 26.2$ billion. 678 dams are considered to be highhazard potential." This deteriorating infrastructure has a huge effect on California's 
economy. A greater delay in investment will increase the costs of aging infrastructure systems.

\section{East Bay Municipal Utility District Challenge of Aging Water Infrastructure}

The East Bay Municipal Utility District (EBMUD) provides drinking water to 1.4 million people in Alameda and Contra Costa counties on the east side of the San Francisco Bay (EBMUD, 2013a). The main source of water is the Mokelumne River watershed in the foothills of the Sierra Nevada Mountains, located about 90 miles northeast of the San Francisco East Bay Area. Water is collected in the Pardee Reservoir on the western slope of the Sierra Nevada Mountains and delivered to the East Bay Area through the 82-mile Mokelumne Aqueduct, which consists of three large diameter steel pipelines of 65, 67, and 87 inches, built in 1929, 1949, and 1963, respectively. Approximately 15 miles of the pipelines run across the Sacramento-San Joaquin Delta: nearly 10 miles of elevated pipeline, 4.5 miles of buried pipeline, and three river crossings with half a mile of submerged pipeline (Prashar, Irias, \& Shewbridge, 2009). According to the California Department of Water Resources (DWR), the Delta is an area of interconnected waterways surrounded by about 60 islands that have supplied agricultural land since the mid-1800s. The islands are protected by 1,100 miles of fragile levees up to 100 years old. During the last century, there were over 160 levee failures in the Delta.

In 2008, DWR completed the Delta Risk Management Strategy (DRMS) Project to perform a risk analysis of the San Joaquin Delta (Phase 1) and to develop improvement strategies to manage the risks (Phase 2). In addition, EBMUD has evaluated the risks and 
provided possible mitigations for potential hazards affecting the Mokelumne Aqueduct. These risks are evaluated in the context of the DRMS process. Based on probabilistic methods and analysis, it is not possible and economical to eliminate all risks.

The completed studies helped decision-makers better understand the issues and make appropriate decisions to protect the water supplies in the Delta. The government tends to invest in new projects instead of maintaining the existing infrastructure, which results in higher costs and lower quality standards. In order to make both cost-effective and wise long-term investments in the critical lifelines, EBMUD conducted planning studies to identify a long-term solution to improve the reliability of the water transmission system across the Delta. Accordingly, the District proposed a new deep tunnel with dual pipelines across the Delta as the preferred long-term protection alternative based on the results of the risk assessment. The identified tunnel alignment follows the right-of-way for the existing Mokelumne Aqueduct. Because it will take several years to accomplish a long-term protection strategy, short-term improvements of the critical lifelines are essential to meet present-day requirements.

Recently, EBMUD has initiated a comprehensive asset management system to set priorities and evaluate the reliability of existing facilities, the cost of replacement versus rehabilitation, and the effects of downtime or failure. The first step is the evaluation of the fragility of the aqueducts' foundation across the Delta as the critical component of EBMUD's water system. 


\section{Background}

EBMUD, a public utility in California, supplies drinking water, provides pollution prevention and wastewater treatment services, and generates renewable energy.

\section{EBMUD Water Sources}

Central Sierra supply. According to EBMUD (2013a), the Mokelumne River on the western slope of the Sierra Nevada collects melted snow from Alpine, Amador, and Calaveras counties. This protected watershed provides $90 \%$ of the water used by EBMUD, which has rights to use up to 364,000 acre-feet of water per year from the Mokelumne River.

The District stores water in Camanche and Pardee Reservoirs and is licensed to store 209,950 acre-feet water per year in Pardee Reservoir, which is equivalent to a 10-month supply for EBMUD’s customers. Camanche Reservoir, 10 miles downstream from Pardee Dam, has a capacity of 417,120 acre-feet to store water for EBMUD's customers.

Local/emergency supply. A 6-month emergency supply is maintained in local reservoirs. The EBMUD (2013a) stores up to 151,670 acre-feet of water in the East Bay reservoirs to provide local emergency supplies. In addition, Bayside Groundwater Injection Well is being used to transfer water into a deep underground aquifer for storage.

Sacramento River supply. According to EBMUD (2013a), during a drought period or emergency, the Mokelumne River cannot supply what the customers need. The Sacramento River is the supplemental source of water, which provides up to 100 million gallons per day. When needed, EBMUD draws water from the Freeport Regional Water 
Facility through a pipeline and the Folsom South Canal and then transfers the water south to the Mokelumne Aqueduct. Figure 1 shows EBMUD water sources.

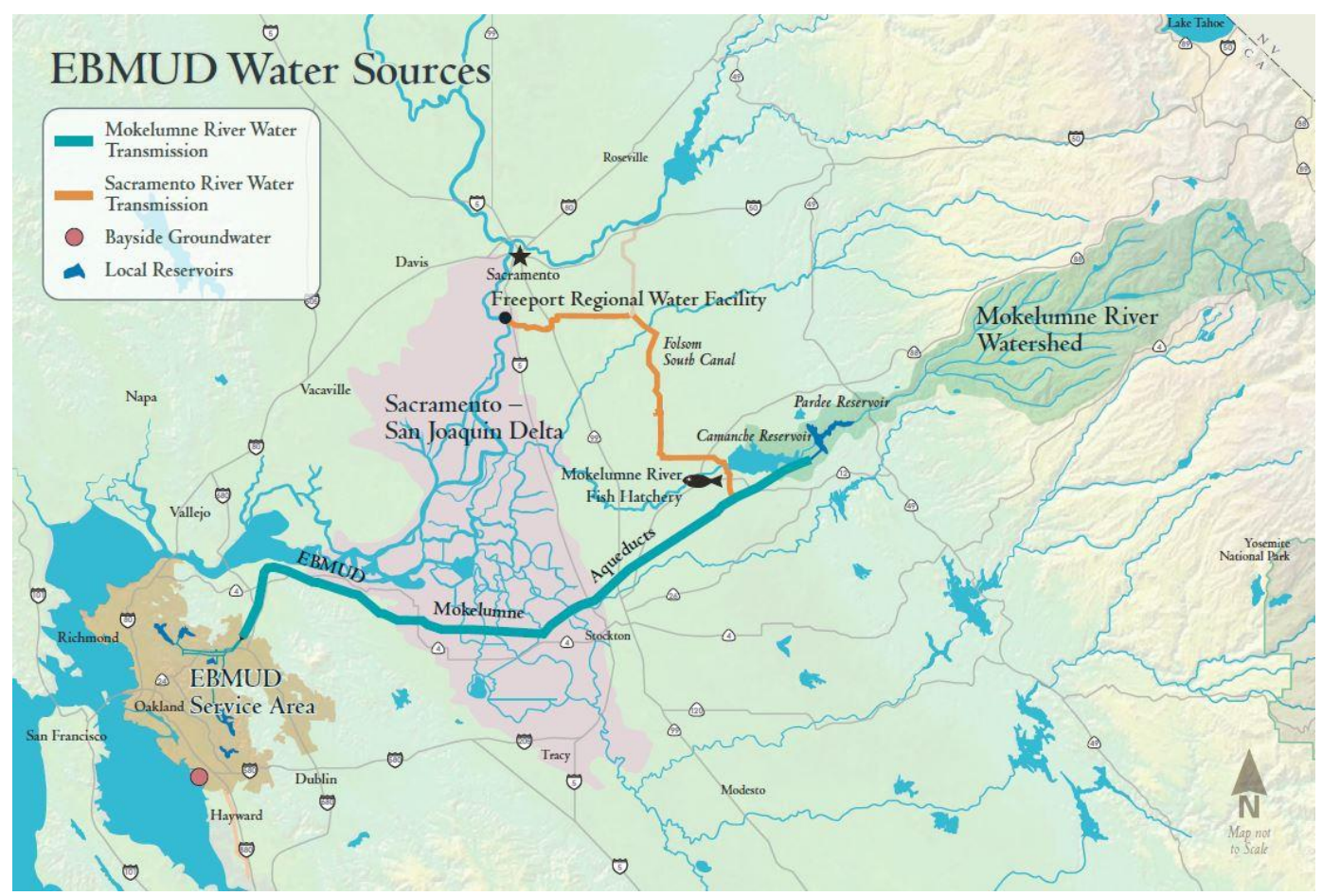

Figure 1. EBMUD water sources. Adapted from “All About EBMUD” by EBMUD, 2013.

\section{Mokelumne Aqueduct in the Delta}

The study area includes approximately 15 miles of the aqueducts that cross the Delta through five islands. The area extends from the outskirts of Stockton in the east to EBMUD's maintenance yard at Bixler in the west. The Delta crossing consists of nearly 10 miles of elevated pipeline, 4.5 miles of buried pipeline, and three major river crossings with approximately half a mile of submerged pipeline (Prashar et al., 2009). Figure 2 shows the location of the Delta crossing, along the aqueducts' alignment. Figure 3 illustrates the location of buried and elevated pipelines, river crossings, and road crossings in the study area. 


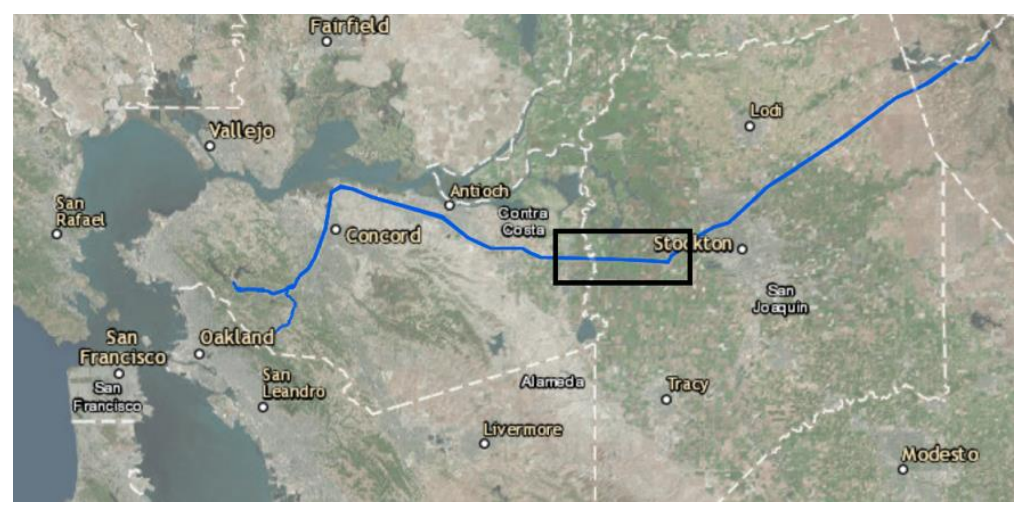

Figure 2. Location of Delta area crossing. The map is adapted from EBMUD GIS Online Mapping Center by Esri, 2013.
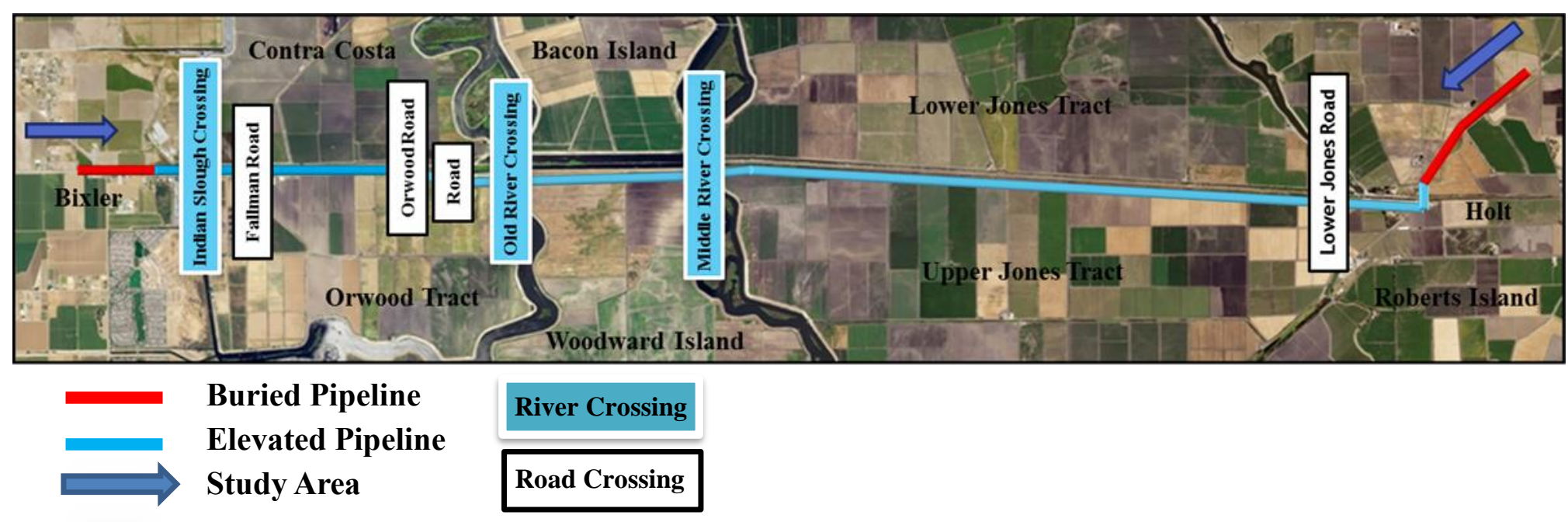

Figure 3. Study area in the Delta. The map is adapted from Google maps. 


\section{Mokelumne Aqueduct}

According to EBMUD (2013a), the Mokelumne Aqueduct is a 95-mile water supply which begins at Pardee Reservoir (formed by Pardee Dam on the Mokelumne River). Mokelumne Aqueduct travels southwest through the western foothills of Sierra Nevada and then west across the Central Valley and along the Calaveras River before crossing the Sacramento-San Joaquin River Delta. Close to Lodi, an extension of the Folsom South Canal is joined by the three aqueducts to supplement the Mokelumne River supply. In the Berkeley Hills above the East Bay, it is channeled into a distribution system including six terminal reservoirs (Briones, Chabot, Lafayette, San Pablo, and Upper San Leandro). Before passing through the Claremont Tunnel (on the western side of the range between Berkeley and Oakland), the water is treated at the Sobrante, San Pablo, and San Leandro treatment plants.

The three aqueducts follow a common alignment along their entire lengths from Pardee Reservoir (Station 0) through Stockton, Brentwood, and Port Chicago to the Walnut Creek Pumping Plant in Contra Costa County, California (Station 4500), with Aqueduct No. 1 in the middle, and Aqueducts No. 2 and No. 3 located approximately 15 feet south and 25 feet north of Aqueduct No. 1, respectively (EBMUD, 2013a).

Aqueduct No. 1. Completed in 1927, Aqueduct No. 1 is 65 inches in diameter. On both sides of and across Indian Slough, the elevated aqueduct is supported on as-built battered timber piles (30 feet apart) with no major retrofit over the years. From Indian Slough to Holt, a major retrofit was performed on the aqueduct's foundation in 1990. Since then, the aqueduct is supported on two battered timber piles, precast concrete bent, 
and 12 inch by 6 inch redwood saddle or hard plastic saddle every 30 feet. The average subsidence along the alignment of Aqueduct No. 1 through the delta is assessed in this study.

Aqueduct No. 2. Completed in 1949, Aqueduct No. 2 is 67 inches in diameter. The elevated portion of the aqueduct is supported on pile groups (60-foot intervals). Aqueduct No. 2 is not included in this study.

Aqueduct No. 3. Completed in 1963, Aqueduct No. 3 is 87 inches in diameter. The elevated portion of the aqueduct is supported on pile groups (60-foot intervals). A pile group consists of at least four piles, and each pile is driven on a 3 vertical to 1 horizontal (3V:1H) batter, in directions of 30 degrees from the perpendicular to the pipeline. The projections of the centerlines of the four piles intersect at a vertical distance of 9.5 feet above the top of the piles. There are 775 pile groups with four piles (BENT I) and 50 pile groups with one additional vertical pile (BENT II) or two additional vertical piles (BENT III), as shown in Appendix A, Figure A1. When one or more of the battered piles did not meet the specified driving resistance during installation, the vertical piles were added within the battered group. There are 35 saddles (each saddle has two battered piles) in the transition zones from the elevated to the under-river crossings. In addition, there are 44 temperature anchors spaced at nearly 1000-foot intervals. The temperature anchors are supported on groups of 10 to 12 battered piles in directions parallel and at right angles to the pipeline. There are 19 pile groups located at bends and road crossings; each has more than 10 piles (all or most of the piles are battered). There is a large bend structure near 
Holt which has 101 piles. The stability of Aqueduct No. 3 is evaluated in this study.

Figure 4 shows the Mokelumne Aqueduct including Aqueducts No. 1, No. 2, and No. 3.

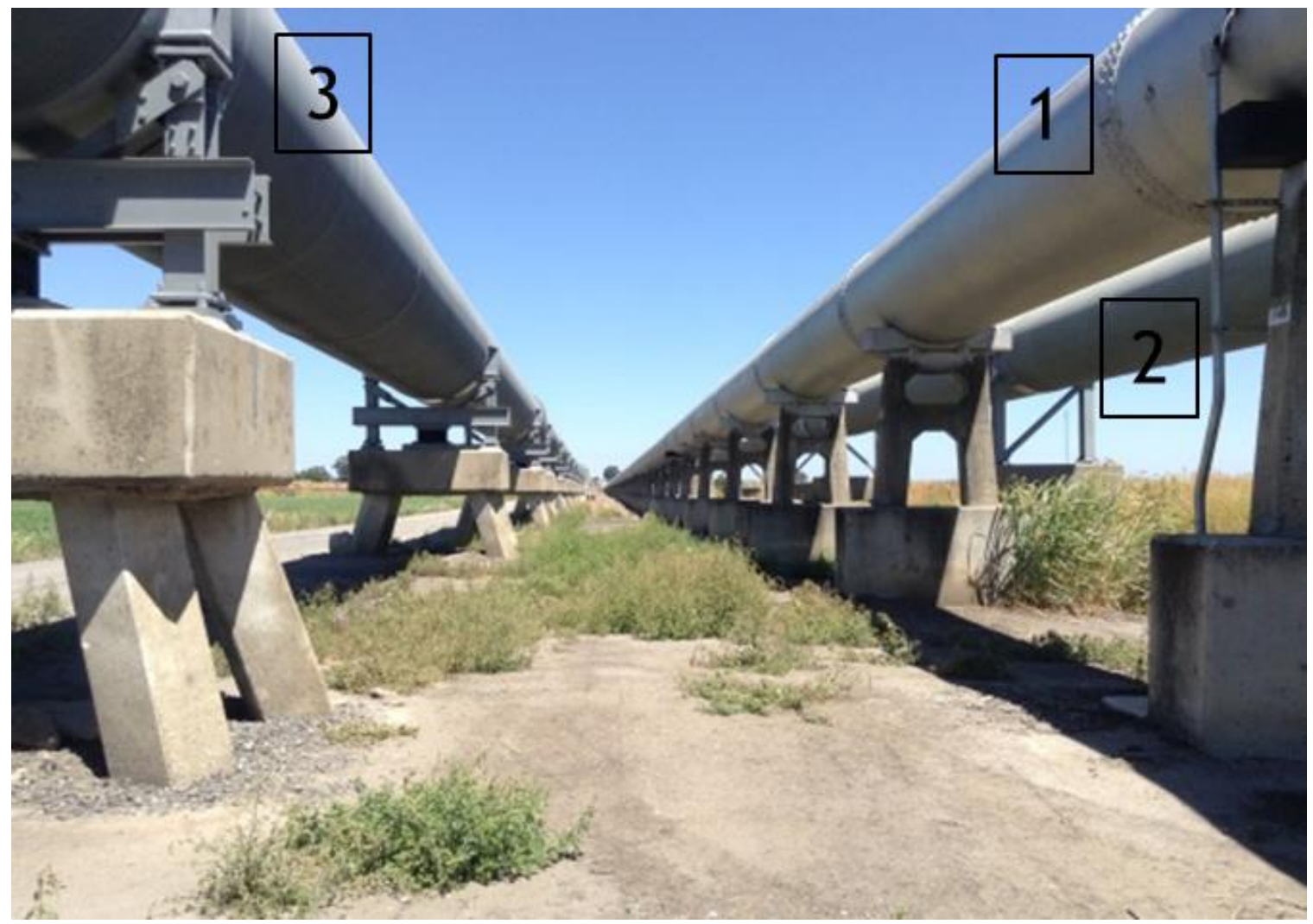

Figure 4. Mokelumne Aqueduct, Sacramento-San Joaquin Delta, California. June, 2017. Aqueducts No. 1, No. 2, and No. 3.

\section{Sacramento-San Joaquin Delta}

The Delta legal boundary. According to DWR, portions of Alameda, Contra Costa, Sacramento, San Joaquin, Solano, and Yolo counties make up the Delta. Each county is responsible for the planning and zoning of land use. Figure 5 shows the Delta's official boundary. It also presents the Delta uplands and lowlands and the Delta service area (the irrigated lands within the Delta that receive water directly from its channels). 


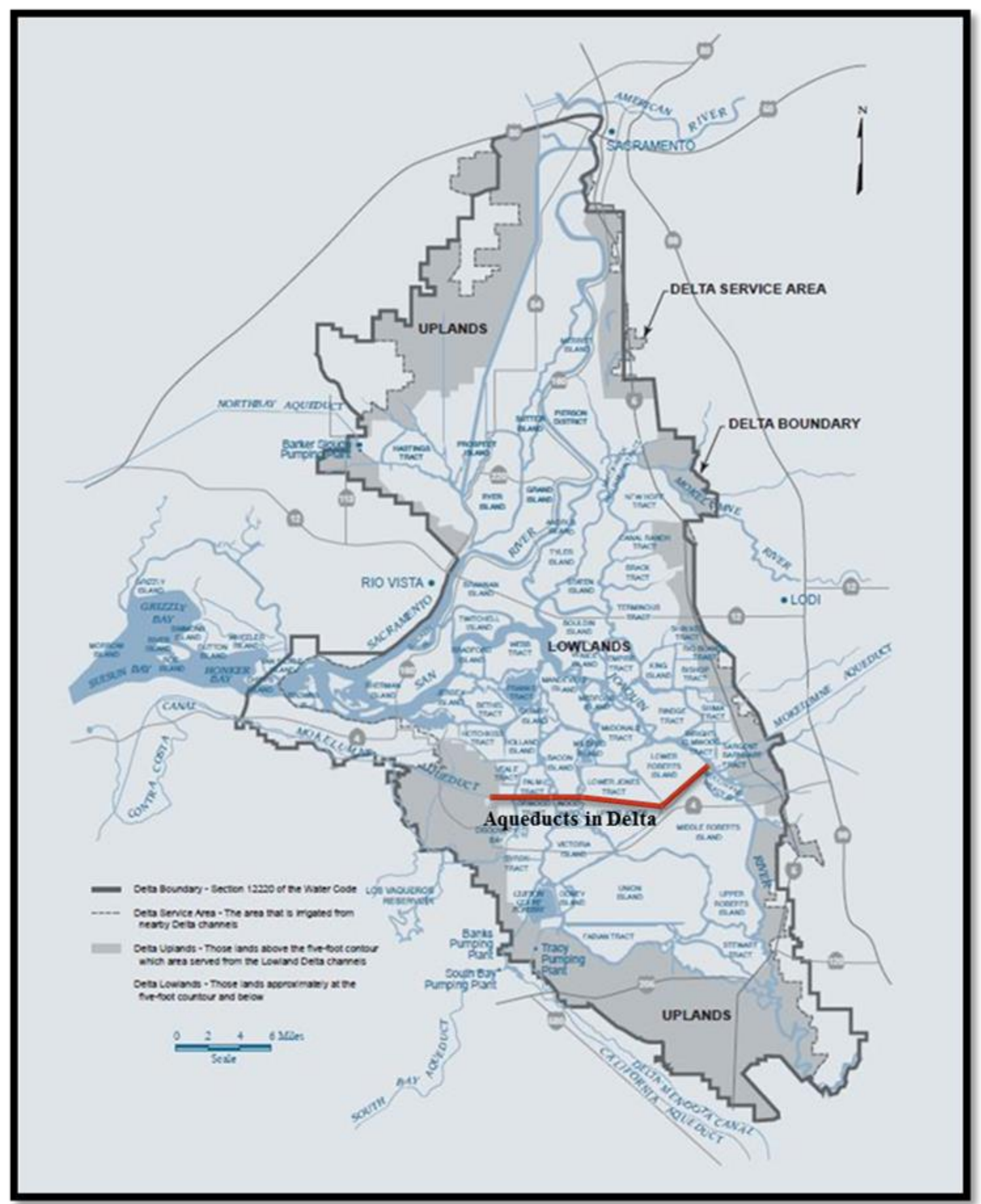

Figure 5. The Delta legal boundary. Adapted from "Delta Overview" by the California Department of Water Resources (n.d.). 
The Delta subsurface. Delta subsurface is composed of the following four main strata (Prashar et al., 2009):

Levee Fills: Located at river crossings, the stratum consists of mixed fine sands, silts, and clays with occasional peat lenses. Levee fills are susceptible to liquefaction under moderate levels of horizontal ground acceleration $(0.1 \mathrm{~g})$.

Peat: This layer runs along much of the aqueducts' alignment and consists of highly compressible organic material up to 30 feet thick. The peat material varies from fibrous to decayed organic matter. It is also mixed with varying amounts of silt and clay. In general, the peat layer has low unit weight, high moisture content, low shear strength, and high compressibility. Peat soils can continue to settle for several years after loading. The top of the peat layer is located at and below sea level.

Holocene alluvium: Underlying the peat, these soils are generally of moderate shear strength and consist of medium stiff clays and silts with loose to medium dense sandy soils typically towards the top of the stratum. This layer is generally below the groundwater, and the material is susceptible to liquefaction during earthquakes.

Pleistocene alluvium: This layer underlies the entire alignment at depths starting at about 40 feet. It consists of dense sands of variable silt content with interbedded zones of stiff to very stiff clays. This layer is generally of higher density, higher shear strength, and lower compressibility, and it is generally not susceptible to liquefaction.

Subsidence in the Delta. Due to river flow and tidal action over the last several million years, upstream sediment was deposited in the Delta and thick organic soil (peat) was formed. Peat is both highly productive for agriculture and very susceptible to 
subsidence. Causes of peat subsidence are (1) oxidation of soil organic matter, (2) shrinkage as a result of dewatering, (3) burning, (4) consolidation as a result of buoyant force and loading, and (5) wind and water erosion. Present subsidence in the Delta is caused mainly by microbial oxidation of organic carbon. Continuous oxidation removes tens of thousands of cubic yards of soil daily (Deverel, Ingrum, \& Leighton, 2016).

The subsidence of peat threatens the Delta infrastructure and water supply for Californians. To determine the risks of subsidence to Mokelumne Aqueduct, it is important to assess the subsidence rates over time. A reduction in landmass decreases levee resistance to hydraulic pressure from adjacent channels; therefore, subsidence has contributed to levee failure and flooding. Future subsidence will increase the volume of water that flows onto islands during flooding, increasing levee vulnerability. Moreover, the downward movement of the land surface causes the loss of lateral support against the aqueducts' deep foundation, which can adversely impact resistance to static and dynamic lateral loading.

DWR has estimated the future subsidence rate in the Delta as a function of soil organic matter content. Using ArcGIS Spatial Analyst, DWR predicted land-surface elevations for 2050, 2100, and 2200. The study has projected the following subsidence rates: 0 to 5 feet by 2050, 0 to over 9 feet by 2100, and 0 to over 18 feet by 2200 . Figure 6 shows the estimated land surface elevation changes from 1998 to 2050 along the aqueducts' alignment. 


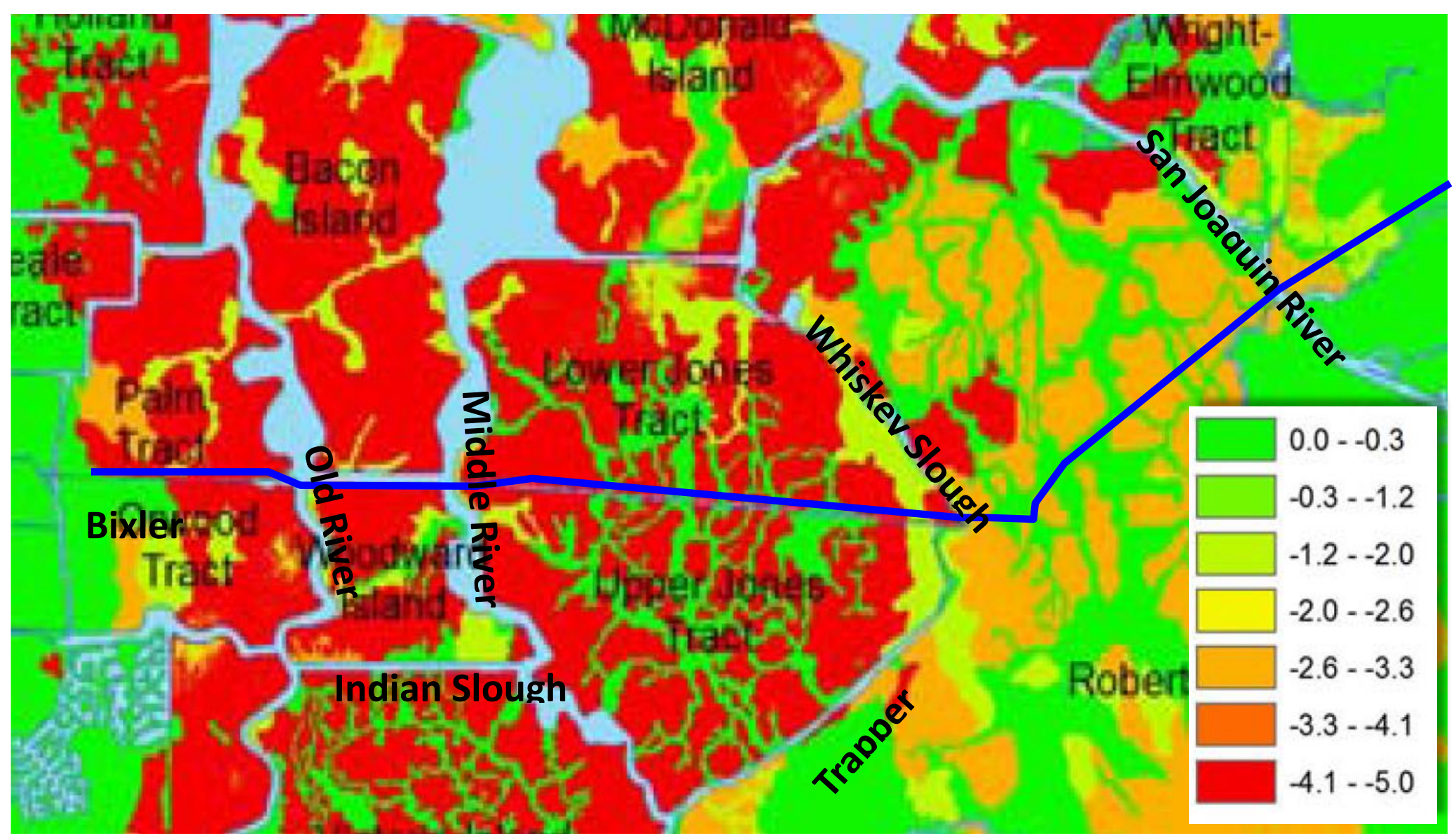

Figure 6. Estimated land surface elevation changes from 1998 to 2050. Adapted from Technical Memorandum: Delta Risk Management Strategy (DRMS) Phase 1- Subsidence by California Department of Water Resources, 2008. 


\section{EBMUD Evaluation of Hazard to Mokelumne Aqueduct in the Delta}

EBMUD has assessed seismologic, flooding, and geotechnical hazards and their associated risks to the existing water supply. The following hazards have been considered (Prashar et al., 2009):

- High water level and tidal action in the channels

- Flooding and levee instability due to subsidence of the islands, overtopping, wave action, or underseepage

- Earthquake shaking

- Additional settlement due to construction dewatering

- Highly compressible peat soil, which is susceptible to large magnitudes of settlement and is causing land subsidence

- Low lateral resistance of near-surface peat soils during earthquakes

- The potentially liquefiable soils in and beneath Delta islands

- Liquefaction-induced lateral spreading at river crossings

Table 1 provides a summary of the risks and the qualitative probabilities of occurrence within three different time periods. 
Table 1

Summary of Hazards and Associated Probabilities (Qualitative)

\begin{tabular}{|l|c|c|c|}
\hline Hazard Description & Year 2040 & Year 2100 & Year 2200 \\
\hline Sea level rise & High & High & High \\
\hline Subsidence & High & High & High \\
\hline Flooding & High & High & High \\
\hline Scouring & Medium & High & High \\
\hline Seismic/ground shaking & High & High & High \\
\hline Liquefaction & High & High & High \\
\hline Lateral spreading & High & High & High \\
\hline Fault crossings & Low & Low & Low \\
\hline Wave propagation & High & High & High \\
\hline Landsliding & Low & Low & Low \\
\hline
\end{tabular}

Note. Adapted from "East Bay Municipal Utility District's Mokelumne Aqueduct in the Sacramento-San Joaquin Delta: Hazard Evaluation” by Y. Prashar, X. J. Irias, S. E. Shewbridge, 2009.

\section{EBMUD Strategy for Protecting Mokelumne Aqueduct in the Delta}

The strategy for protecting the aqueducts in the Delta presents a process to help decision-makers understand the investment options to protect water supplies and make cost-effective and wise long-term investments in EBMUD's infrastructure. To this end, EBMUD evaluated possible mitigations for hazards affecting the aqueducts and the costs of these mitigation activities. The strategy in place combines short-term mitigations, to lower risks quickly, with long-term mitigations that lower them significantly. Short-term improvements were also evaluated because a long-term protection strategy would take several years to implement.

Short-term protection alternative. The short-term strategies are envisioned to provide lower-cost mitigations in the near term and an almost immediate reduction of identifiable risks. 
In 2000, a seismic upgrade to Aqueduct No. 3 provided a measure of vulnerability reduction. Seismic isolation was implemented by using a mechanical device located between the aqueduct and the foundation. This isolator is designed to relieve destructive earthquake movement by separating the superstructure from the ground (EBMUD's consultant, 1999). Figure 7 shows the location of the seismic isolation between Aqueduct No. 3 and the pile cap to protect the aqueduct against seismic forces.

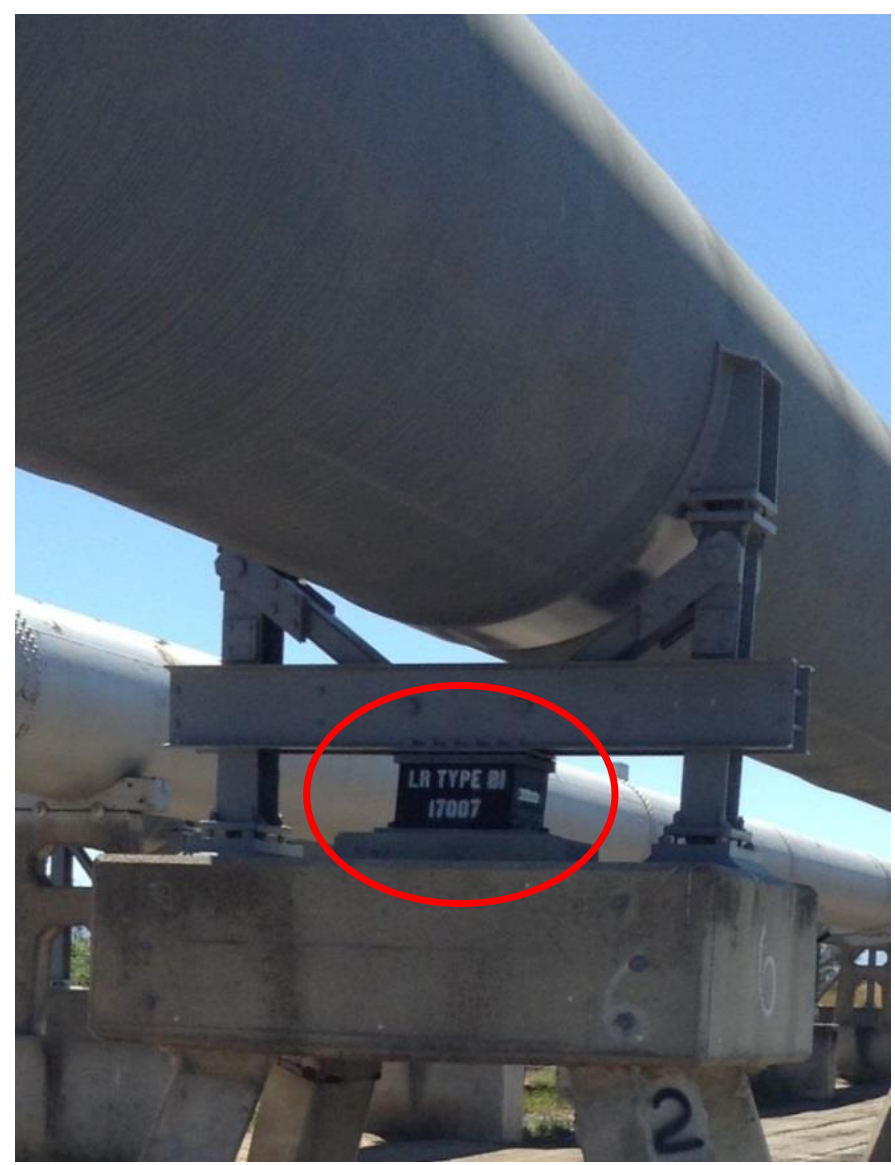

Figure 7. Aqueduct No. 3 seismic upgrade, Sacramento-San Joaquin Delta, California. June, 2017. Base isolator on Aqueduct No. 3 (2000).

In 2013, interconnections between the aqueducts were constructed on the eastern and western sides of the Delta to provide temporary risk reduction. In the event that all three 
aqueducts should fail, the interconnections would not be effective. Further, the reinforcement of the levees on the water side of the pipeline-levee crossing provides significant protection against pipeline failure caused by lateral spreading and liquefaction where the pipelines cross the levees (Prashar et al., 2009).

Long-term protection alternative. In 2000, the District initiated studies to identify a long-term solution to improve the reliability of the water supply across the Delta. In a 2007 report, the District identified a new deep tunnel with dual pipelines across the Delta as the preferred long-term mitigation alternative. The proposed Delta tunnel is currently both the most effective long-term mitigation plan and one of the lower-cost alternatives studied. The Delta tunnel alignment is envisioned to follow the existing right-of-way for the pipelines, extending about 16.5 miles from where the aqueducts cross under Interstate Highway I-5 in Stockton to the District's Bixler Maintenance Yard on the west side of the Delta. Further geotechnical studies and subsurface investigations are essential to minimize uncertainties in geologic conditions, identify the potential depth of liquefaction along the proposed tunnel alignment, refine the optimal tunnel depth, and evaluate the potential impact of tunnel excavation on existing pipelines. 


\section{Methodology}

The Sacramento-San Joaquin Delta soils are composed of mineral sediments delivered by the rivers and peat derived from decaying marsh vegetation. Subsidence is caused primarily by the ongoing oxidation of peat. Studies (CA DWR - DRMS, 2008) on subsidence in the Delta have predicted 3 to 4.5 feet of additional subsidence between the years 1998 to 2050. To assess the amount of subsidence over time along the aqueducts' alignment, data obtained by surveying in 1967 and 2004, and LiDAR data (Light Detection and Ranging) have been used. Subsidence or loss of lateral soil support against piles and pile caps can adversely impact resistance to lateral (static and seismic) loading.

Because Aqueduct No. 3 is the most reliable among the three aqueducts, it was evaluated for stability in this study. First, the aqueduct's deep foundation pile cap types (bent, saddle, temperature anchor, road anchor, bend anchor, and combination anchor) were identified and variations in subsurface conditions were investigated. The subsurface soils along the alignment are generally loose peaty soil deposits overlying alternating layers of loose unconsolidated and potentially liquefiable Holocene deposits to depths over 150 feet. In addition, site-specific strong ground motion parameters were identified based on different studies.

Next, a series of axial and lateral single pile (APILE/LPILE) and pile group (GROUP) analyses were performed to assess the service limit state of the aqueduct's deep foundation pile caps. The applied lateral load (p) as a function of the lateral deflection (y) of the pile head was also investigated. 
Finally, the lateral load that would produce the anticipated deflection was computed. The result was compared with both the maximum expected lateral load at the pile cap occurring due to seismic ground motion (base shear) and the lateral capacity at the 1-inch horizontal displacement of the pile cap (threshold).

The analysis has quantified the impact of ground loss (due to subsidence in the Delta) on pile lateral and axial capacities along the aqueduct's alignment. The analytical studies are presented and discussed in order to develop retrofit alternatives in the future. 


\section{Results and Discussion}

\section{Average Subsidence Analysis}

The Delta soils are composed of mineral sediments delivered by the rivers and of peat derived from decaying marsh vegetation. Subsidence is caused primarily by the ongoing oxidation of peat. The State Department of Water Resources has conducted the Delta Risk Management Strategy program (DRMS) on subsidence in the Sacramento-San Joaquin Delta and predicted 3 to 4.5 feet of additional subsidence between the years 1998 and 2050. This amount of subsidence or loss of lateral soil support against piles and pile caps can adversely impact resistance to lateral (static and seismic) loading.

In order to determine the amount of subsidence over time along the aqueducts' alignment, the following sets of data were used to detect and predict the average subsidence:

- $\quad$ 1966, 2010 and 2015 survey data (EBMUD)

- 2007 LiDAR data (United States Geological Survey)

By taking advantage of ArcGIS (Geographic Information System mapping tools), LiDAR data along the aqueducts' alignment were selected from the Delta area database.

Aqueduct No. 1 alignment. Two sets of LiDAR data were selected from the Delta area database (Figure 8):

1. Top of the aqueduct (blue line)

2. 6-foot offset from the aqueduct centerline (red line) 


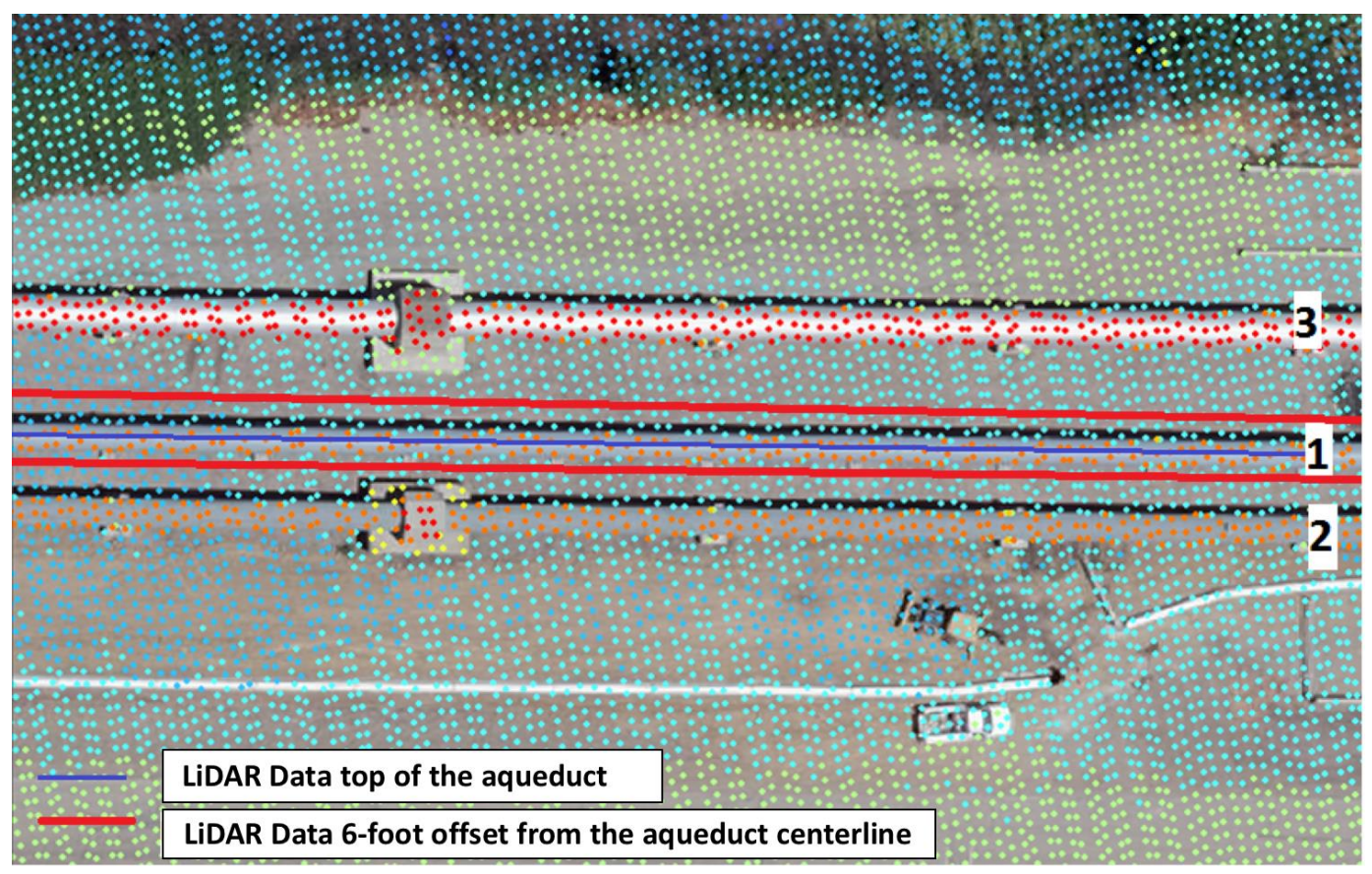

Figure 8. Aqueduct No. 1 LiDAR data 2007. Adapted from EBMUD GIS Online Mapping Center by Esri, 2013.

Selected sets of data were used to produce Figure 9, and noisy data were eliminated. In addition, ground surface elevation survey data (EBMUD, 1966) were added. The distance between ground surface elevation in 2007 (red line) and ground surface elevation in 1966 (purple line with yellow dots) shows the average subsidence along the aqueducts' alignment from 1966 to 2007 . Figure 10 presents the overall view of Aqueduct No. 1 in the Delta, including pile tip elevation. 


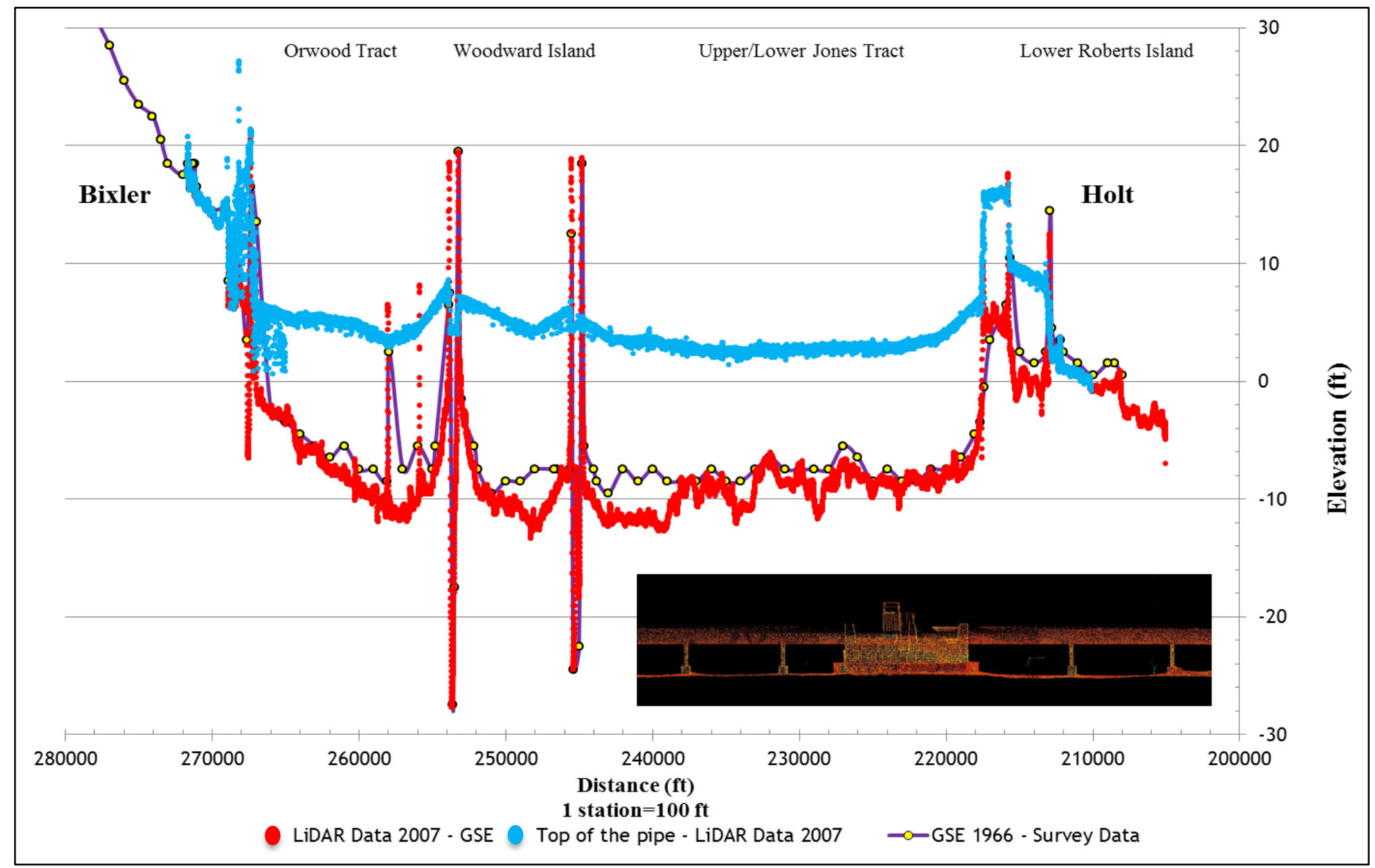

Figure 9. Average subsidence along Aqueduct No. 1 from 1966 to 2007. The graph is adapted from data from EBMUD GIS Online Mapping Center by Esri, 2013. 


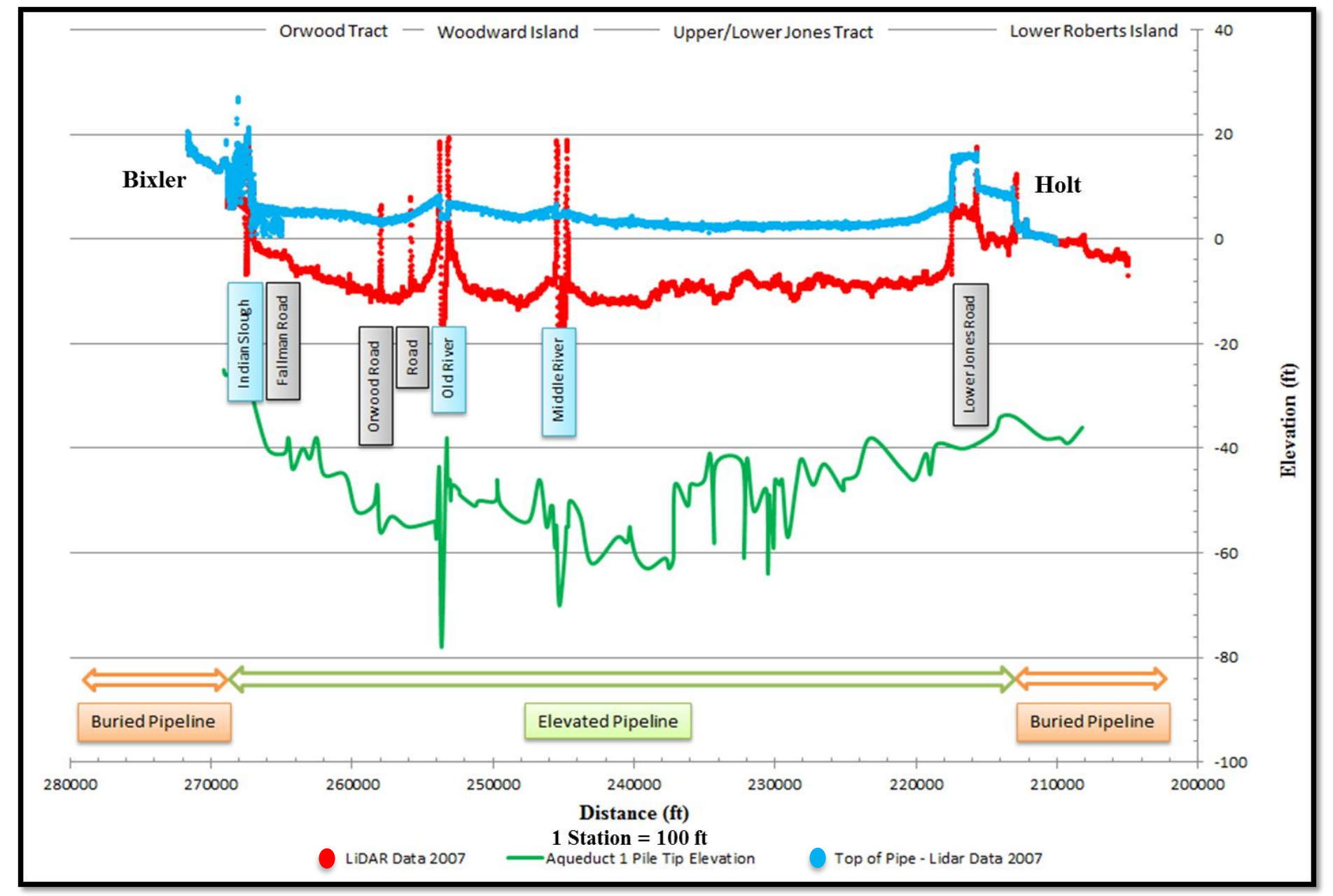

Figure 10. Overall view of Aqueduct No. 1 in the Delta. The graph is adapted from data from EBMUD GIS Online Mapping Center by Esri, 2013. 
Aqueduct No. 3 alignment. Three sets of LiDAR data were selected from the Delta area database (Figure 11):

1. Top of the aqueduct (purple line)

2. Top of the pile cap (blue line)

3. 10-foot offset from the aqueduct centerline (red line)

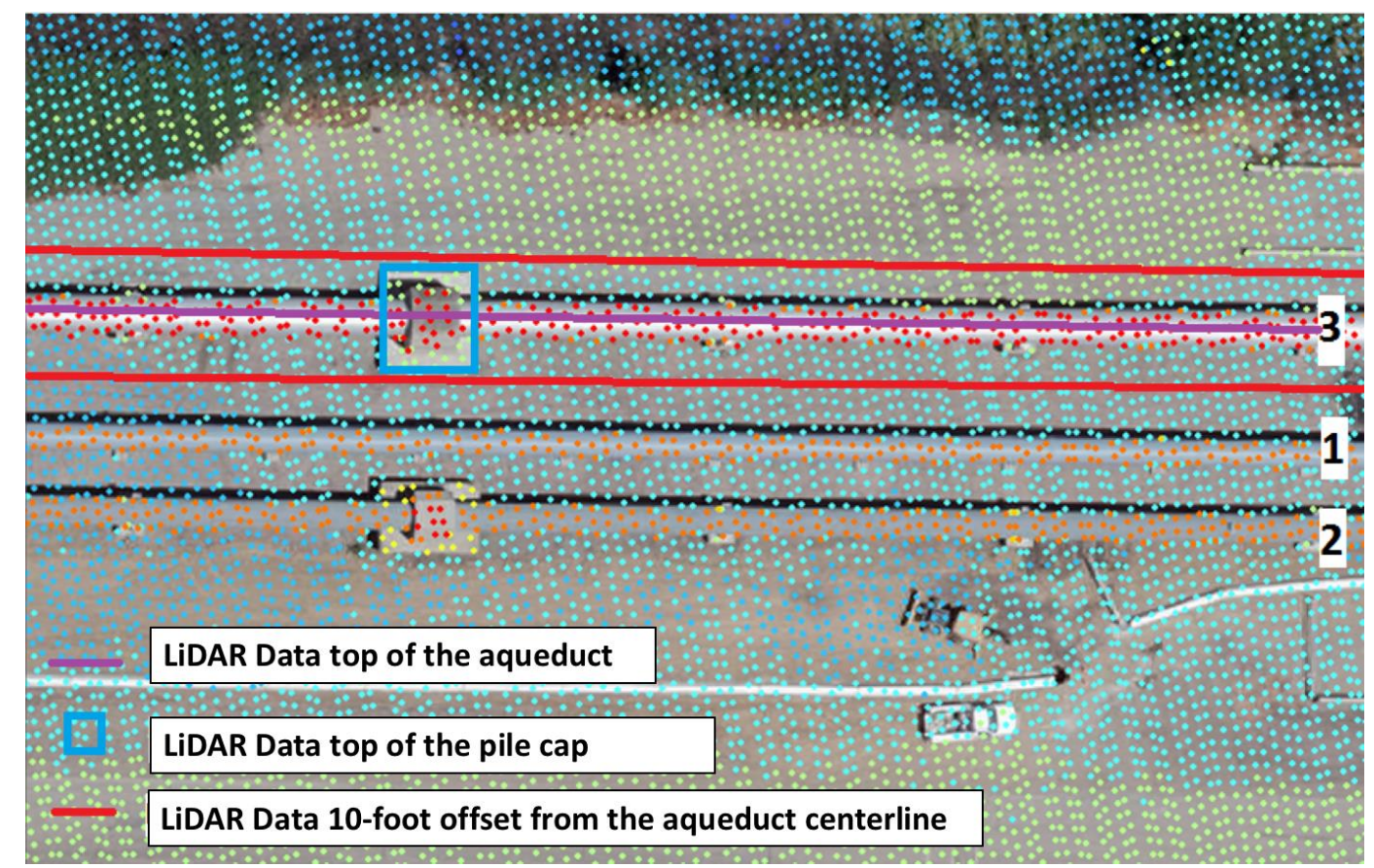

Figure 11. Aqueduct No. 3 LiDAR data 2007. Adapted from EBMUD GIS Online Mapping Center by Esri, 2013.

Selected sets of data were used to produce Figure 12, and noisy data were eliminated. In addition, survey data (EBMUD, 2010; and EBMUD, 2015) were added. Due to the short time frame from 2007 to 2010 and 2015, the average subsidence is not visible. Figure 13 presents the overall view of Aqueduct No. 3, including pile tip elevation. 


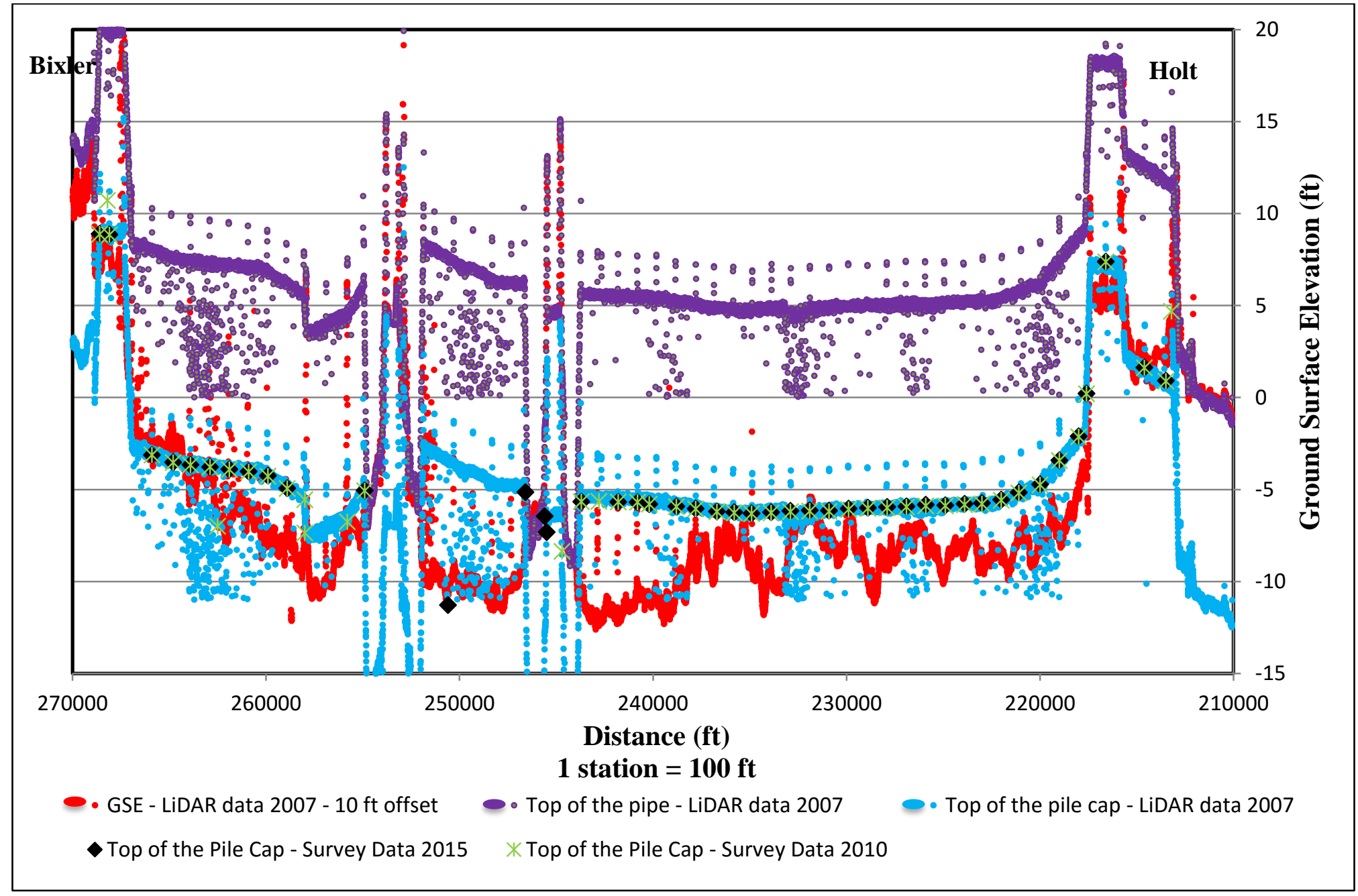

Figure 12. Average subsidence along the Aqueduct No. 3 from 2007 to 2015. The graph is adapted from data from EBMUD GIS Online Mapping Center by Esri, 2013. 


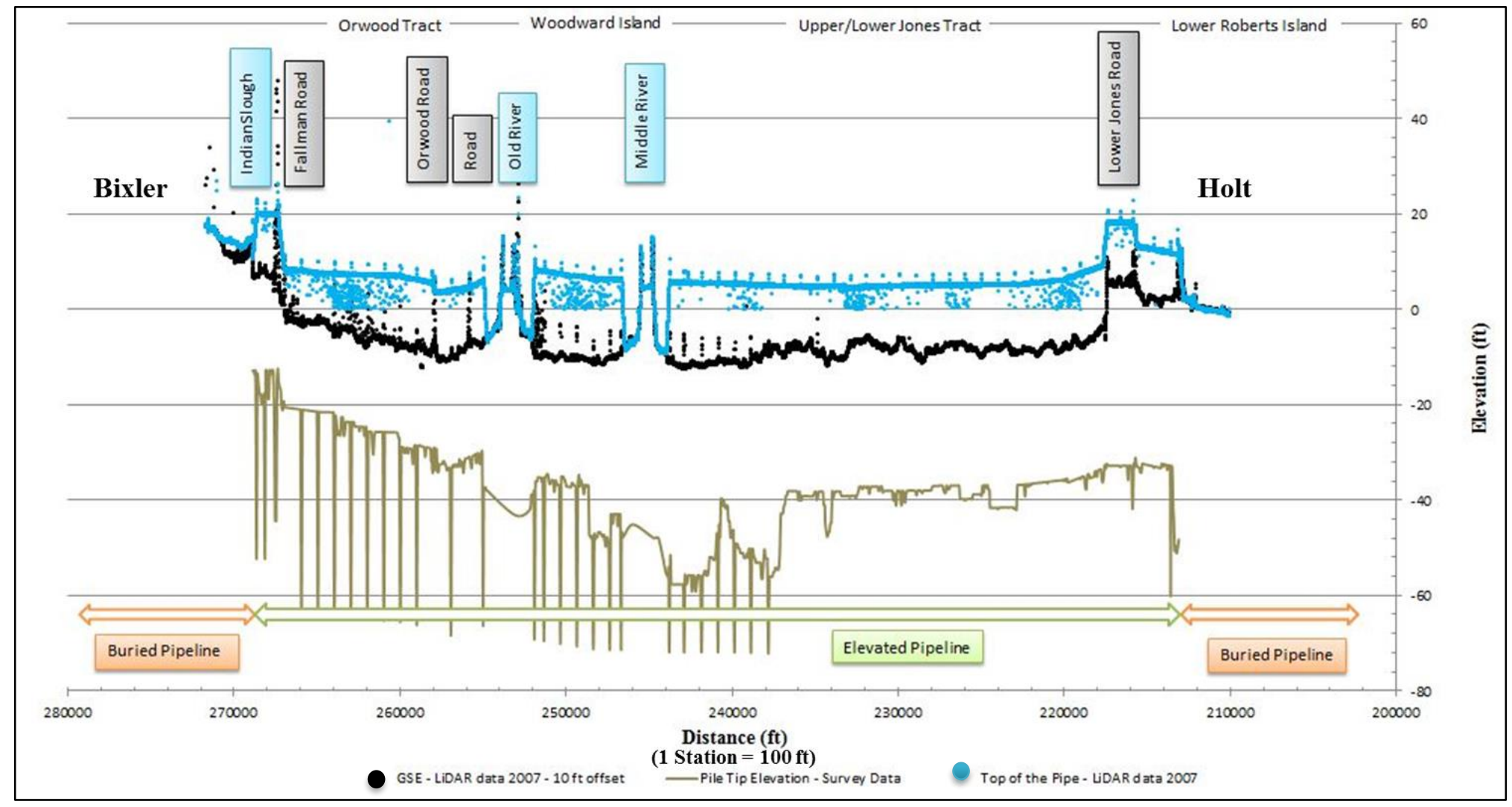

Figure 13. Overall view of Aqueduct No. 3 in the Delta. The graph is adapted from data from EBMUD GIS Online Mapping Center by Esri, 2013. 
Taking all of the previous studies into account, it can be concluded that the average subsidence is 3.5 feet along the aqueducts' alignment from 1998 to present. In this study, the same subsidence rate ( 3.5 feet over 20 years) is predicted in the future.

\section{Structural Features}

Because Aqueduct No. 3 is the most reliable among all three aqueducts, it was used for the stability evaluation. There are 775 pile groups with four piles (BENT I) and 50 pile groups with one additional vertical pile (BENT II) or two additional vertical piles (BENT III). Therefore, $94 \%$ of the bents are type I, and only $6 \%$ are types II and III; thus, BENT I was used in this study (see Appendix A, Figure A1). Aqueduct No. 3 is entirely supported on 16-inch square pre-stressed concrete piles driven on 3 vertical to 1 horizontal (3V:1H) batter (see Appendix A, Figure A2). Pile properties are listed in Appendix A, Table A1.

Axial load on pile. The axial load on each pile group was calculated by summing up the dead load (DL) of the pipe, the steel bent, the pile cap, and water in the pipe. Also, the seismic vertical load and load factor (1.2 DL) were considered in this calculation (see Appendix A, Table A2). The axial load on each pile was calculated by dividing the total axial load on the pile group by the number of piles in each pile group. Table 2 provides the amount of axial load on each vertical and battered pile. 
Table 2

Axial Load on Each Vertical and Battered Pile

\begin{tabular}{|c|c|c|c|c|}
\hline BENT Type & $\begin{array}{c}\text { No. of } \\
\text { Piles }\end{array}$ & $\begin{array}{c}\text { Load per } \\
\text { Vertical Pile } \\
\text { (kips) }\end{array}$ & $\begin{array}{c}\text { Pile Batter } \\
\text { Angle } \\
\text { (degree) }\end{array}$ & $\begin{array}{c}\text { Load per } \\
\text { Battered Pile } \\
\text { (kips) }\end{array}$ \\
\hline BENT I & 4 & 75.6 & 18 & 79.5 \\
\hline BENT II & 5 & 60.5 & 18 & 63.6 \\
\hline BENT III & 6 & 50.4 & 18 & 53 \\
\hline
\end{tabular}

Note. The axial load on each pile was calculated by dividing the total axial load on the pile group by the number of piles in each pile group.

Degree of fixity of pile. In order to determine the degree of fixity of each pile, the American Concrete Institute (ACI) has provided ACI 318-14, Table 25.4.2.2 to calculate the development length for different bar sizes in order to obtain $100 \%$ fixity (see Appendix A, Table A3).

According to the specification ASTM-A15, grade 33 and 40 rebar were used between 1911 and 1966. Appendix A, Table A4 presents all the parameters needed to calculate the development length for the bars to achieve $100 \%$ fixity at the pile cap. Accordingly, the existing development length ( 24 inches) provides $92 \%$ fixity with grade 33 bars, and $76 \%$ fixity with grade 40 bars (Table 3 ).

Table 3

Degree of Fixity of Pile at Pile Cap

\begin{tabular}{|c|c|c|c|}
\hline $\begin{array}{c}\text { Rebar } \\
\text { Grade }\end{array}$ & $\begin{array}{c}\text { Development } \\
\text { Length (in) } \\
\text { 100\% fixity }\end{array}$ & $\begin{array}{c}\text { Existing } \\
\text { Development } \\
\text { Length (in) }\end{array}$ & $\begin{array}{c}\text { Degree of } \\
\text { Fixity }\end{array}$ \\
\hline 33 & 26.1 & 24 & $92 \%$ \\
\hline 40 & 31.6 & 24 & $76 \%$ \\
\hline
\end{tabular}

Note. Existing development length (24 inches) provides $92 \%$ fixity with grade 33 bars, and $76 \%$ fixity with grade 40 bars. 
Pile group action. Group action should be considered when the pile spacing in the direction of lateral loading is less than 6 to 8 times the pile width (pile width $=16$ inch). Pile spacing at the pile head (in the direction of lateral loading) increases with depth due to the pile batter angle $(3 \mathrm{~V}: 1 \mathrm{H})$. Therefore, pile spacing at ground surface is more than 8 times the pile width. In conclusion, a group action evaluation is not required.

\section{Seismic Study}

Two different seismic studies were considered in order to identify the peak ground acceleration (PGA) along the aqueducts in the Delta:

- United States Geological Survey (USGS)

- AECOM seismic study (AECOM, 2017a)

The lower of the deterministic and probabilistic ground motions has been considered as the PGA by USGS. The results are comparable with those obtained from the AECOM seismic study of the proposed Delta Tunnel Project (see Appendix B, Figure B1, Figure B2, and Figure B3).

The study area was divided into four regions based on the effect of near-fault ground motion on the 15 miles of aqueducts in the Delta (Figure 14). The results of the seismic studies were compared at Region 1 . Table 4 compares the results at a return period of 475 years, while Table 5 is related to a return period of 2475 years. The results of the studies at both return rates were in good agreement. 


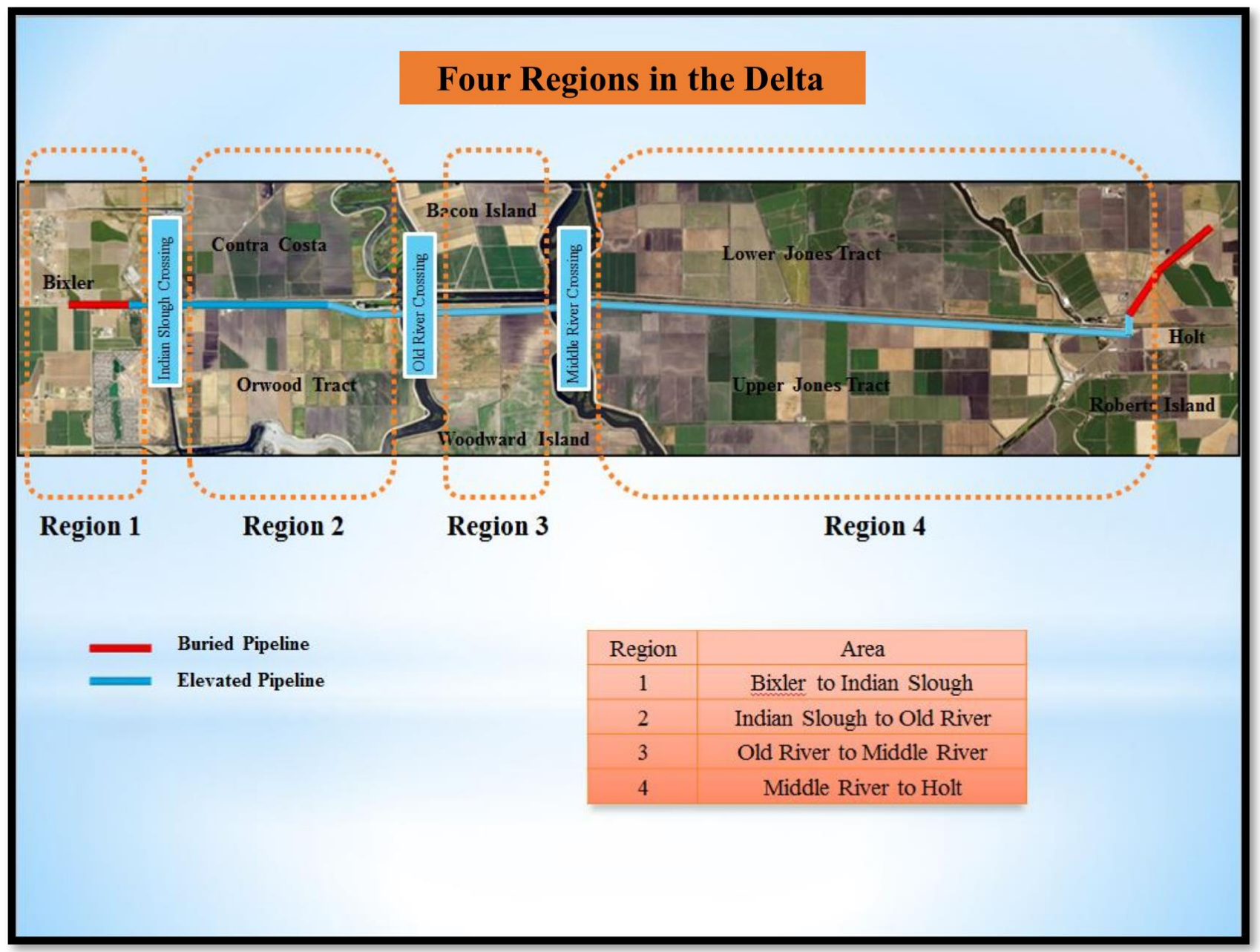

Figure 14. Four regions in the Delta. The map is adapted from Google maps. 
Table 4

PGA from Two Seismic Studies (475-Year Return Period)

\begin{tabular}{|c|c|}
\hline Bixler to Indian Slough & PGA \\
\hline USGS deterministic study & 0.42 \\
\hline $\begin{array}{c}\text { USGS probabilistic study } \\
\text { (Return period: } 475 \text { years) }\end{array}$ & 0.49 \\
\hline $\begin{array}{c}\text { Lower of deterministic } \\
\text { and probabilistic study }\end{array}$ & 0.42 \\
\hline $\begin{array}{c}\text { AECOM seismic study } \\
\text { (Return period: 475 years) }\end{array}$ & 0.42 \\
\hline
\end{tabular}

Note. USGS data are adapted from "U.S. Seismic Design Maps" by United States Geological Survey. AECOM data are adapted from Delta Tunnel Seismic Study ReportPhase 1 by AECOM, 2017.

Table 5

PGA from Two Seismic Studies (2475-Year Return Period)

\begin{tabular}{|c|c|}
\hline Bixler to Indian Slough & PGA \\
\hline $\begin{array}{c}\text { USGS probabilistic study } \\
\text { (Return period: } 2475 \text { years) }\end{array}$ & 0.76 \\
\hline $\begin{array}{c}\text { AECOM seismic study } \\
\text { (Return period: } 2475 \text { years) }\end{array}$ & 0.75 \\
\hline
\end{tabular}

Note. USGS data are adapted from "U.S. Seismic Design Maps" by United States Geological Survey. AECOM data are adapted from Delta Tunnel Seismic Study ReportPhase 1 by AECOM, 2017.

Based on these seismic studies, the PGA at a 475-year return period was estimated for the four identified regions in the Delta. The highest PGA is $0.42 \mathrm{~g}$ at Region 1 in the west, which is closer to active faults; the lowest PGA is $0.37 \mathrm{~g}$ at Region 4 in the east, which is farther from the active faults. Figure 15 presents the location of the Delta aqueducts, the nearby faults, and the variation of PGA along the aqueducts. 


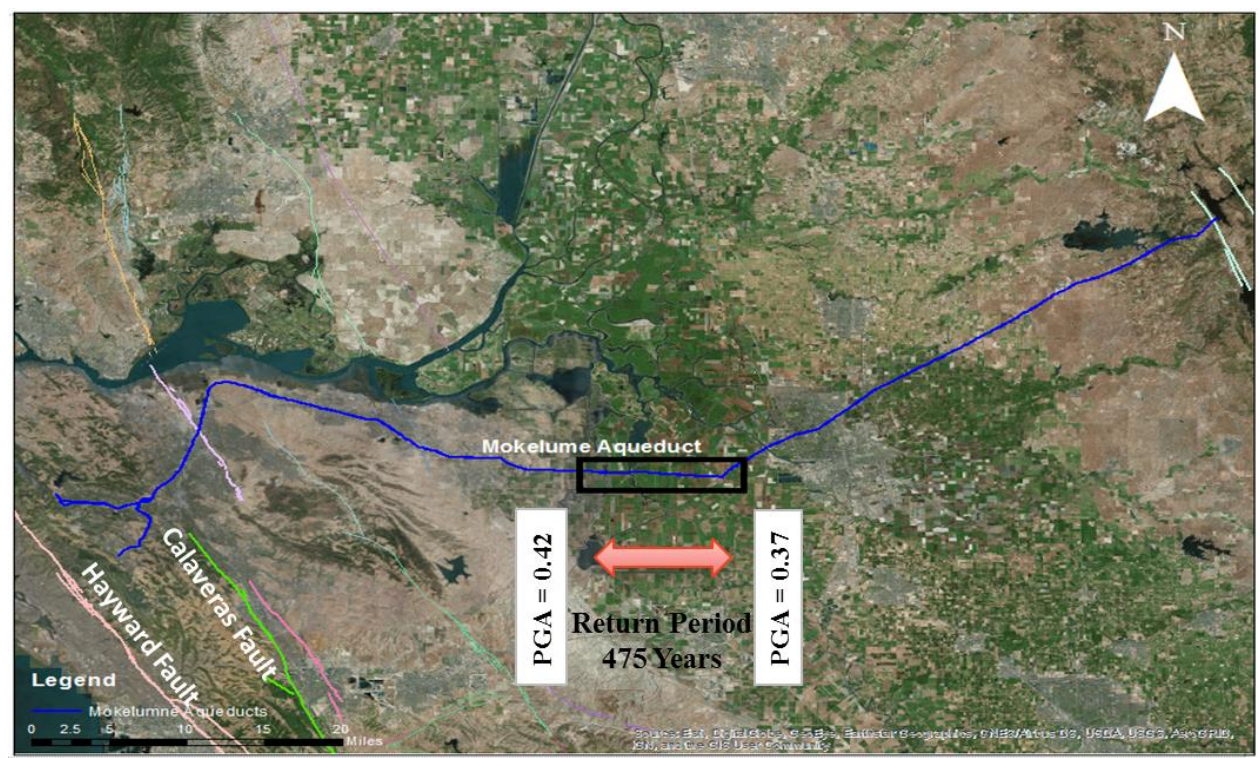

Figure 15. Variation of PGA along the Delta aqueducts. The map is adapted from EBMUD GIS Online Mapping Center by Esri, 2013.

The maximum expected lateral load at the pile cap occurring due to seismic ground motion (base shear) was determined for these four regions in the Delta. Appendix B, Table B1 provides references and parameters for the determination of base shear. Accordingly, Table 6 provides PGA and base shear at the four Delta regions.

Table 6 PGA and Base Shear at Four Regions in the Delta

\begin{tabular}{|c|c|c|c|}
\hline Region & Area & PGA & V $_{\text {base }}$ (kips) \\
\hline 1 & Bixler to Indian Slough & 0.42 & 90 \\
\hline 2 & Indian Slough to Old River & 0.40 & 87 \\
\hline 3 & Old River to Middle River & 0.39 & 84 \\
\hline 4 & Middle River to Holt & 0.37 & 77 \\
\hline
\end{tabular}




\section{Stability Analysis Approaches}

In this study, two different approaches were used to evaluate the stability of the aqueducts' deep foundation:

- APILE/LPILE analysis

- GROUP analysis

APILE, LPILE and GROUP are software products of ENSOFT Inc., based in Austin, Texas.

APILE/LPILE analysis. APILE is used to compute the axial and uplift (tension) capacities of a single pile as a function of depth. Load capacities in side resistance (skin friction) and end bearing are computed, along with the total capacities to sustained axial and uplift loadings (ENSOFT, 2015).

LPILE is used for analyzing a single pile under lateral loading using the p-y method. Depending on pile-head boundary conditions, LPILE computes shear force, bending moment, lateral deflection, pile-head rotation, and soil response over the length of the pile. LPILE can perform pushover analysis to evaluate the pile behavior after the development of plastic hinges or yielding (ENSOFT, 2016a). Figure 16 presents how the ultimate lateral load is computed in APILE/LPILE analysis. Lateral load vs. deflection (P-Y) is computed in LPILE for a single pile, and T (tension) and Q (compression) are computed in APILE for a single pile. For BENT I, the sum of P-Y for four piles, the horizontal component of $\mathrm{T}\left(\mathrm{T}_{\mathrm{H}}\right)$ for two piles, and the horizontal component of $\mathrm{Q}\left(\mathrm{Q}_{\mathrm{H}}\right)$ for two other piles is equal to the ultimate lateral load. 


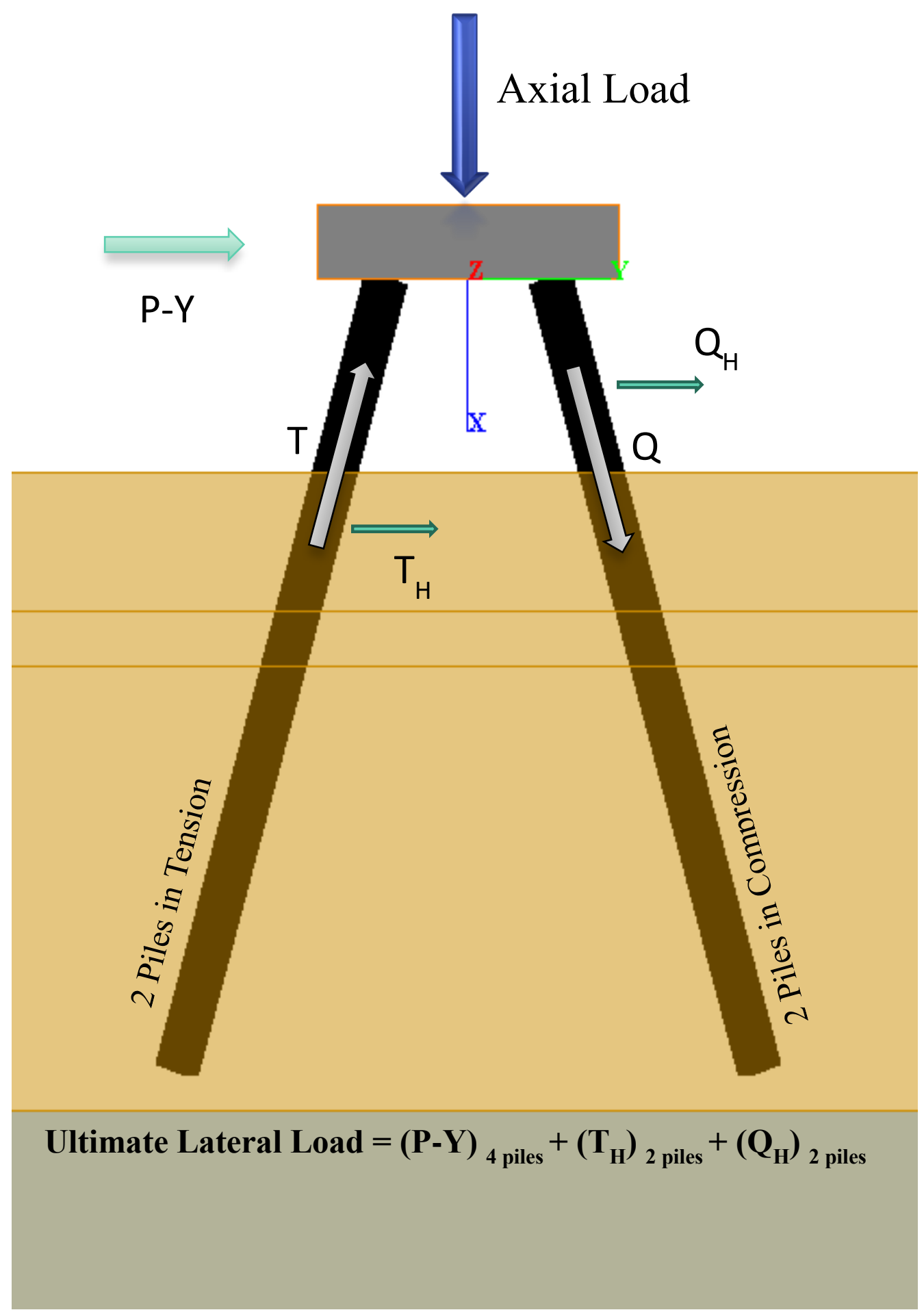

Figure 16. APILE/LPILE analysis approach. The image is adapted from "LPILE” by ENSOFT Inc., 2016. 
GROUP analysis. GROUP is used for analyzing the behavior of piles in a group subjected to both axial and lateral loadings. GROUP provides stiffness and/or flexibility matrices in 2D or 3D models. For closely spaced piles in one group, group effects can be considered, though as stated above the piles in these foundations are not close enough to have an interactive effect on each other. The program computes the force and displacement on the pile cap, such as the axial force (tension and compression), the lateral forces (shear and moment) and the displacement of the pile cap in different directions (ENSOFT, 2016b) (Figure 17).

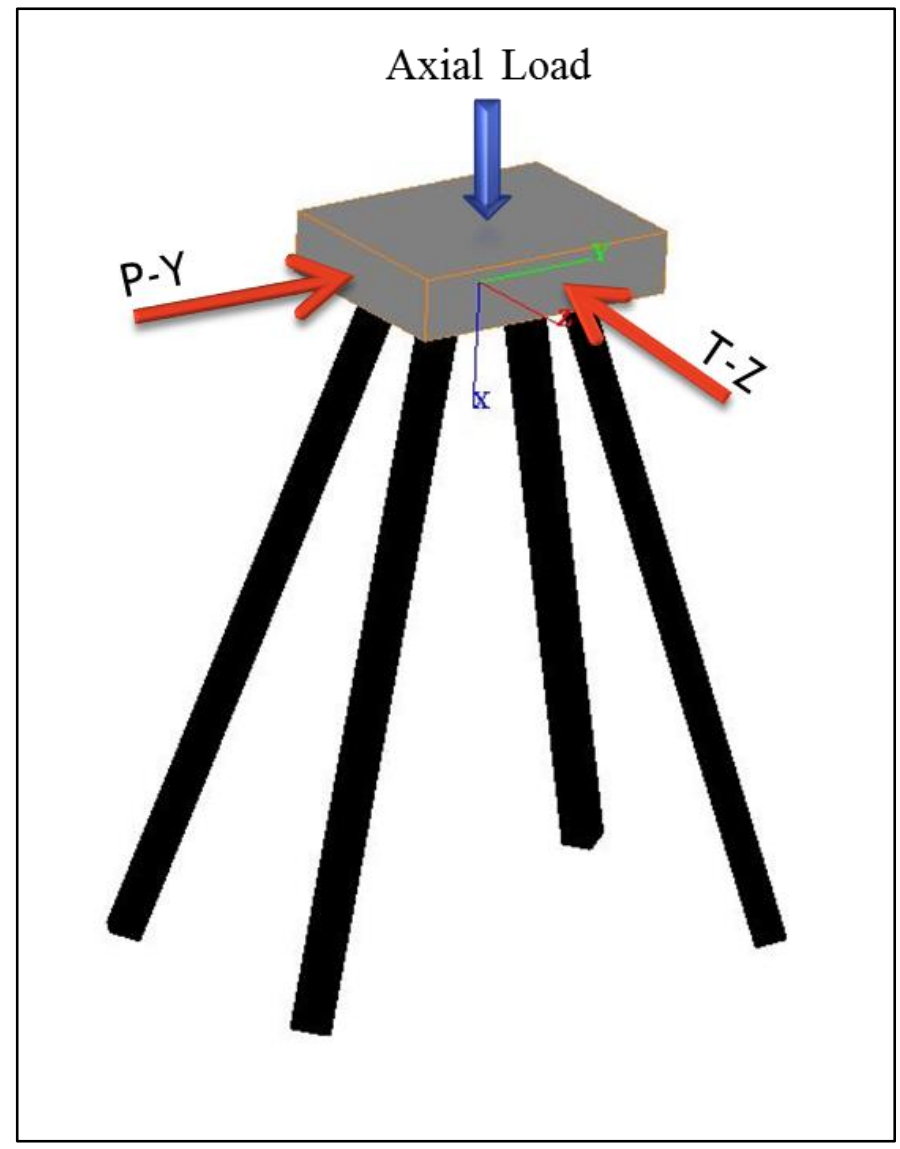

Figure 17. GROUP analysis approach. The image is adapted from "GROUP" by ENSOFT Inc., 2016. 


\section{Analysis Limit State}

Following are the limit states for deep foundation lateral analysis (Samtani, 2017):

- Service limit state

- Strength limit state

- Extreme event limit state

- Fatigue limit state (generally does not apply)

The service limit state relates to deformation by considering the serviceability while the strength limit state relates to structural and/or geotechnical instability by considering the failure aspect. Lastly, the extreme event limit state considers the events likely to occur during the design life of the facility. The service limit state is applicable to this study (Figure 18).

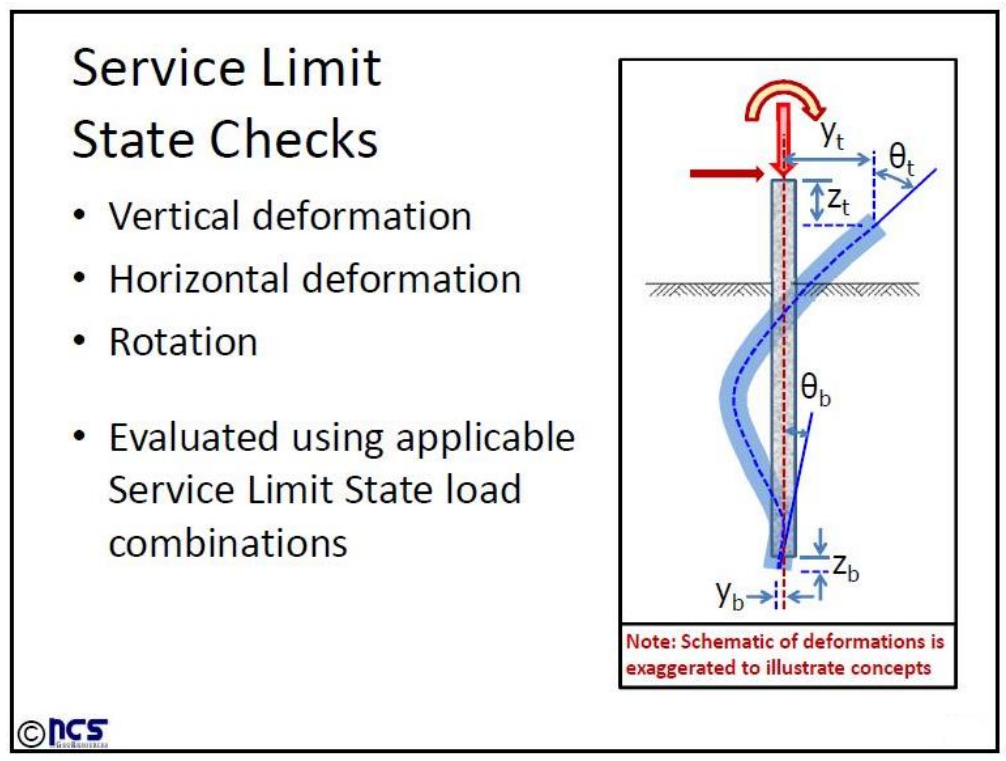

Figure 18. Service limit state. Adapted from "Geotechnical Engineering Features Deep Foundations: Lateral Analysis” by N. C. Samtani, August 28, 2017, ASCE Knowledge and Learning. Copyright 2017 by NCS GeoResources, LLC. 
A series of axial and lateral single pile (APILE/LPILE) and pile group (GROUP) analyses were performed to assess the service limit state of the aqueducts' deep foundation pile cap. The applied lateral load (p) was investigated as a function of the lateral deflection (y) of the pile head. A model computed the lateral load that would produce the desired deflection. The result was compared with both the maximum base shear and the lateral load at the 1-inch horizontal deflection of the pile cap.

\section{Studies in the Delta}

Previous studies on the performance of the aqueducts' foundations in the Delta were examined as part of this analysis. In 1999, a seismic upgrade study was performed on Aqueduct No. 3. In general, the soil profile along the aqueducts' alignment is considered to be composed of three soil types: peat, Holocene alluvium, and Pleistocene alluvium. For analysis purposes, the pipeline alignment was characterized using five profiles, designated as A (A1 and A2), B, C, and D. Pile capacities were calculated using the recommendations in ACI 318-99 and FEMA 356. The ultimate shear capacity was calculated using the recommendations for pre-stressed concrete members in Chapter 11 of ACI 318-99. The ultimate axial and uplift capacities are based upon the soil profile and Cone Penetration Testing (CPT) data (see Appendix C, Table C1).

In 2000, the District initiated planning studies to identify a long-term solution to improve the reliability of the water transmission system across the Delta. In a 2007 report, the District identified a new deep tunnel across the Delta as the preferred longterm mitigation alternative. The proposed Delta Tunnel is envisioned to extend about 16.5 miles from where the aqueducts cross under Interstate Highway I-5 in Stockton to 
the District's Bixler Maintenance Yard on the west side of the Delta. The proposed tunnel alignment follows the existing right-of-way for the aqueduct pipelines. In 2016, EBMUD offered the geotechnical exploration and seismic study of the proposed Delta Tunnel project to AECOM. The firm has conducted a phase 1 field investigation and seismic study. The findings are considered in this study. Appendix C, Figure C1 provides the proposed exploration plan. Appendix C, Figure C2 to Figure C9 provide the boring logs, which are utilized in this study.

\section{Stability Analysis}

A different evaluation has been conducted in each region. Table 7 shows the regions corresponding to each area of evaluation.

Table 7

Regions Corresponding to Each Area of Evaluation

\begin{tabular}{|c|l|l|}
\hline $\begin{array}{c}\text { Evaluation } \\
\text { Order }\end{array}$ & \multicolumn{1}{|c|}{ Region } & \multicolumn{1}{c|}{ Area of Evaluation } \\
\hline 1 & $\begin{array}{l}\text { Region 3: } \\
\text { Old River to Middle River }\end{array}$ & $\begin{array}{l}\text { Evaluation of the 1999 study by } \\
\text { EBMUD's consultant (hereinafter referred } \\
\text { to as “the 1999 study") }\end{array}$ \\
\hline 2 & $\begin{array}{l}\text { Region 4: } \\
\text { Middle River to Holt }\end{array}$ & Subsidence impact evaluation \\
\hline 3 & $\begin{array}{l}\text { Region 1: } \\
\text { Bixler to Indian Slough }\end{array}$ & Liquefiable subsurface impact evaluation \\
\hline 4 & $\begin{array}{l}\text { Region 2: } \\
\text { Indian Slough to Old River }\end{array}$ & Liquefiable subsurface impact evaluation \\
\hline
\end{tabular}

Region 3: Old River to Middle River. The 1999 study of Region 3 was reviewed for the current study. Two different soil profiles considered in this evaluation:

- The 1999 study: Soil profile A2 (Table 8)

- AECOM study: Boring log DT-B6A-2016 (Table 9) 
Table 8

The 1999 Study by EBMUD's Consultant: Soil Profile A2 (Old River to Middle River)

\begin{tabular}{|c|c|l|l|c|c|c|}
\hline Layer No. & Depth (ft) & \multicolumn{2}{|c|}{ Description } & Unit Weight (pcf) & Friction Angle (degree) & Cohesion (psf) \\
\hline 1 & $0-7$ & Holocene peat & Peat & 75 & 0 & 100 \\
\hline 2 & $7-23$ & Holocene alluvium & Lean clay & 100 & 0 & 1000 \\
\hline 3 & $23-50$ & Pleistocene alluvium & Lean clay & 100 & 0 & 2000 \\
\hline
\end{tabular}

Note. Adapted from Aqueduct No.3 Seismic Upgrade by EBMUD's consultant, 1999.

Table 9

AECOM Study: Boring Log DT-B6A-2016 (Old River to Middle River)

\begin{tabular}{|c|c|l|c|c|c|c|}
\hline Layer No. & Depth $(\mathrm{ft})$ & Description & Unit Weight $(\mathrm{pcf})$ & Friction Angle (degree) & Cohesion $(\mathrm{psf})$ & Nq \\
\hline 1 & $0-2$ & Fill & 110 & 30 & 0 & 100 \\
\hline 2 & $2-5.5$ & Peat & 75 & 0 & 1000 & \\
\hline 3 & $5.5-16.5$ & Lean clay & 100 & 0 & 2000 & 0 \\
\hline 4 & $16.5-18.5$ & Lean clay & 100 & 0 & 2000 & 27 \\
\hline 5 & $18.5-32$ & Sand & 120 & 0 & 0 & 47.6 \\
\hline 6 & $32-34$ & Lean clay & 100 & 35 & 0 & 2000 \\
\hline 7 & $34-40$ & Sand & 120 & 100 & 0 & 2017. \\
\hline
\end{tabular}

Note. Adapted from Phase 1 Geotechnical Exploration Program-Delta Tunnel Project (GDR) by AECOM, 2017. 
At this location, the maximum ground acceleration during earthquake shaking is calculated to be $0.39 \mathrm{~g}$, and the maximum expected lateral load at pile cap is calculated to be 84 kips.

Based on the 1999 study, the ultimate lateral capacity of four piles (BENT I) is approximately $220 \mathrm{kips}$, and the horizontal displacement of the pile cap corresponding to the ultimate lateral capacity is 2.7 inches (Figure 19).

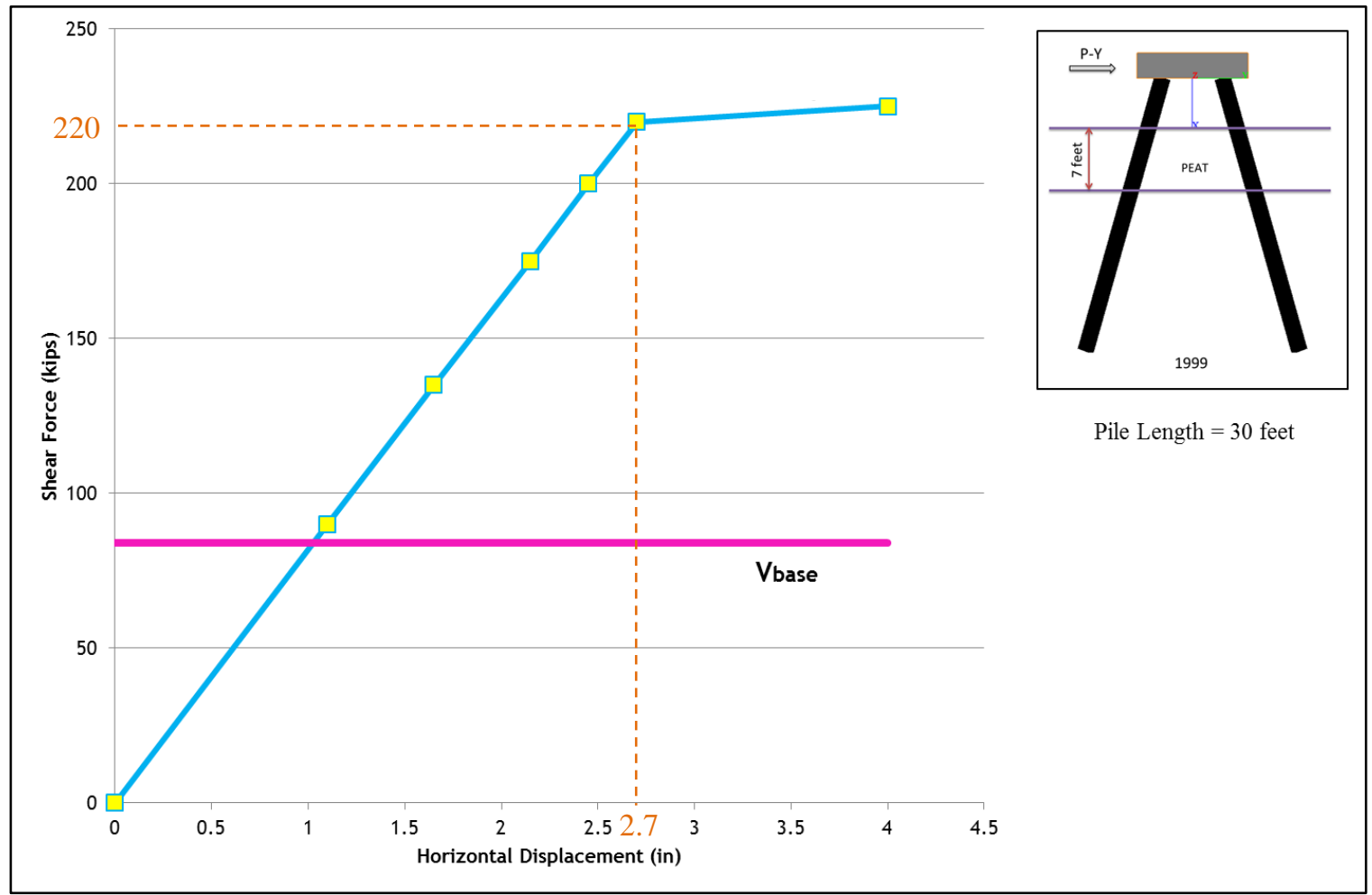

Figure 19. The 1999 study by EBMUD's consultant: Region 3, ultimate lateral capacity of pile group. The data are adapted from Aqueduct No. 3 Seismic Upgrade by EBMUD's consultant, 1999.

APILE/LPILE analysis and GROUP analysis were performed and the soil profile A2 considered. LPILE has the capability to analyze pile behavior after the development of plastic hinges (yielding). GROUP is not able to continue the analysis beyond the limit, so 
output data were extended by extrapolation. Figure 20 presents the results and comparison between the 1999 study and APILE/LPILE and GROUP analyses.

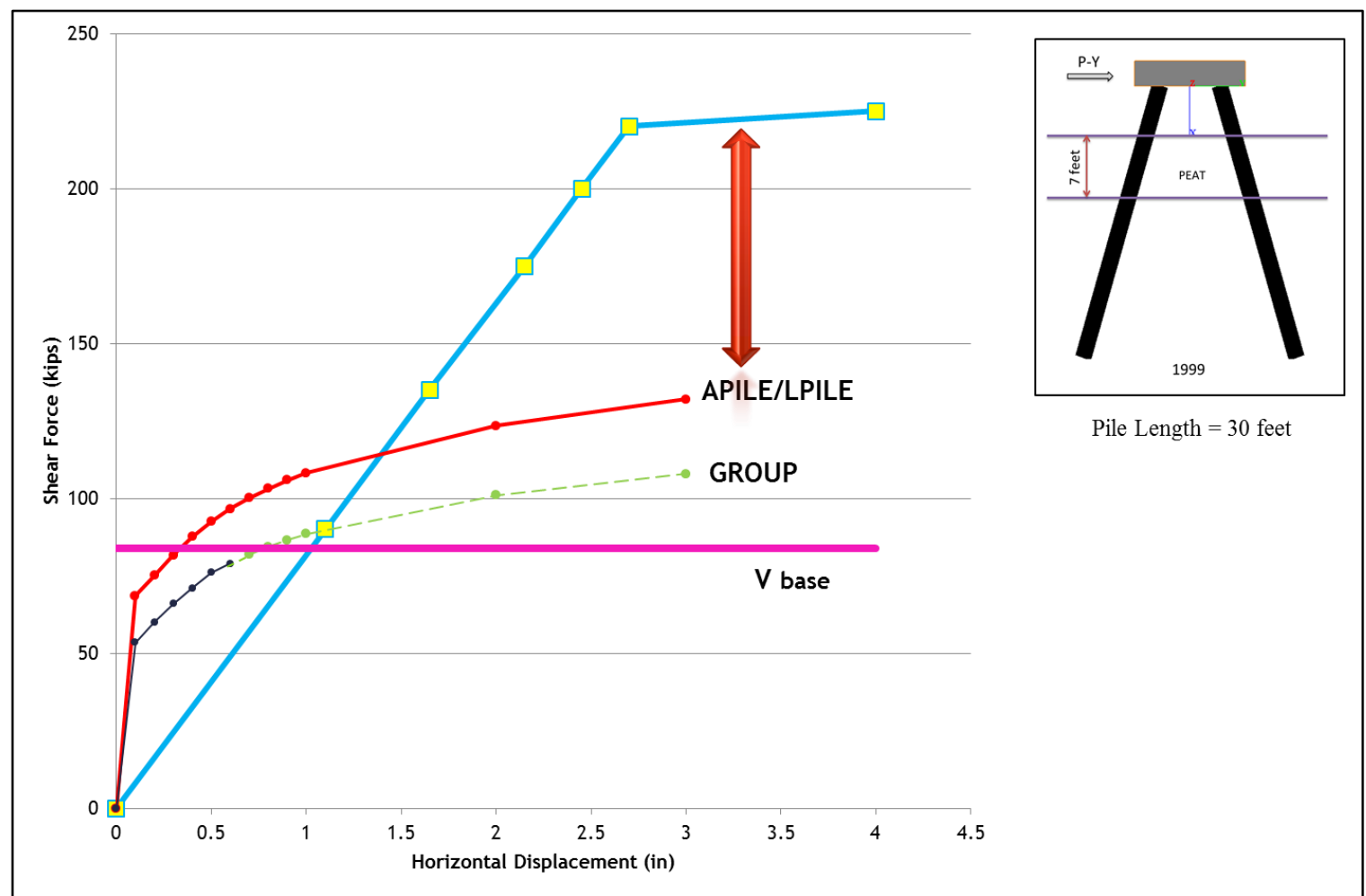

Figure 20. Region 3, comparison between the1999 study by EBMUD's consultant and APILE/LPILE and GROUP analyses. Data from the 1999 study are adapted from Aqueduct No. 3 Seismic Upgrade by EBMUD's consultant, 1999.

To match the ultimate lateral capacity from the APILE/LPILE analysis with the ultimate lateral capacity from the 1999 study, soil cohesion values were increased in APILE/LPILE analysis to approximately twice the value considered in 1999 study. Moreover, a large difference in model initial stiffness response was distinguished (low displacement), as shown in Figure 21.

To match the ultimate axial/uplift capacity assumptions in the 1999 study with the APILE/LPILE analysis, soil cohesion values were increased in APILE/LPILE analysis to 
approximately four times those considered in the 1999 study. A large difference in model initial stiffness response was distinguished (low displacement), as shown in Figure 22.

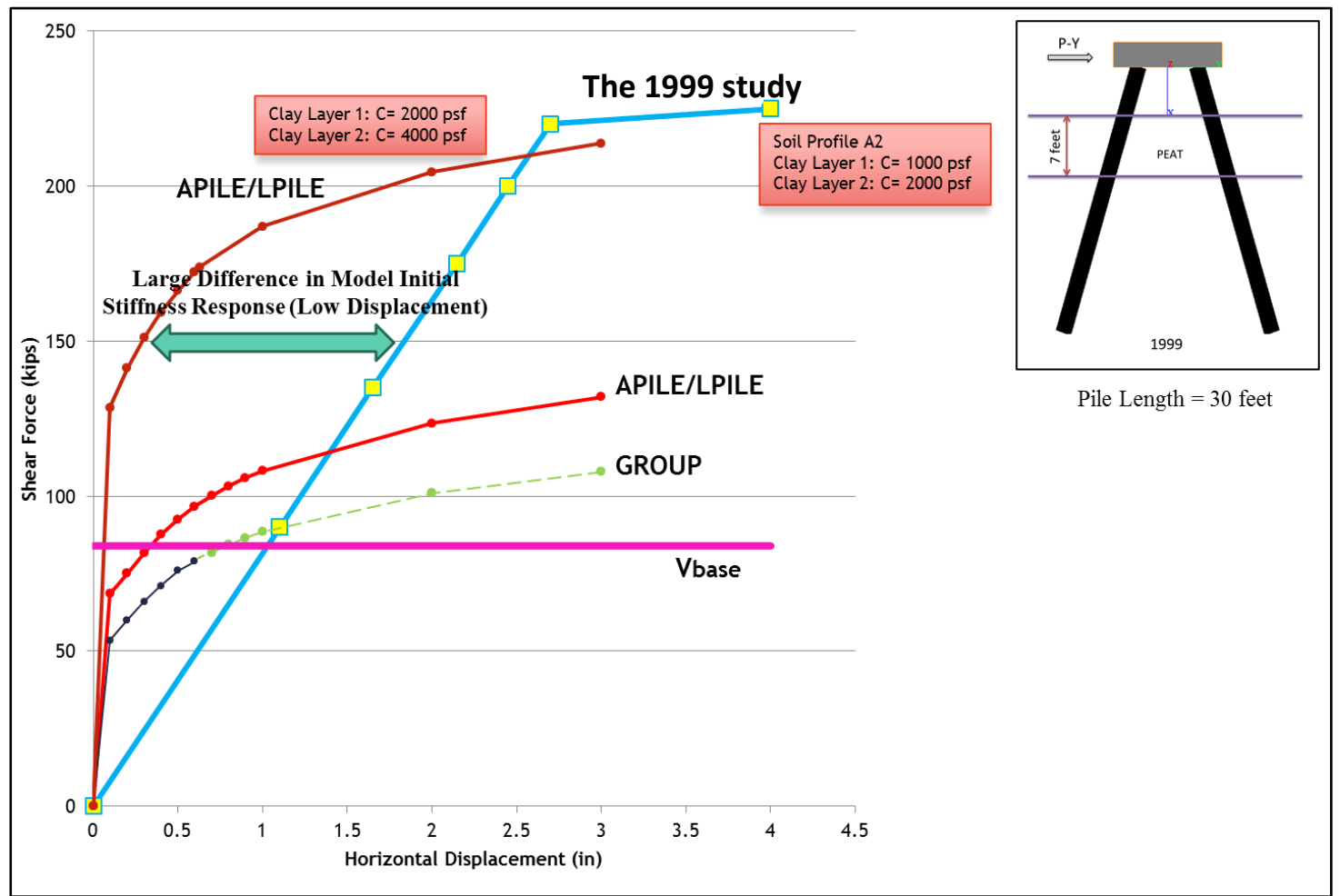

Figure 21. Region 3, matching the ultimate lateral capacity from the APILE/LPILE analysis with the 1999 study by EBMUD's consultant. Data from the 1999 study are adapted from Aqueduct No. 3 Seismic Upgrade by EBMUD's consultant, 1999. 


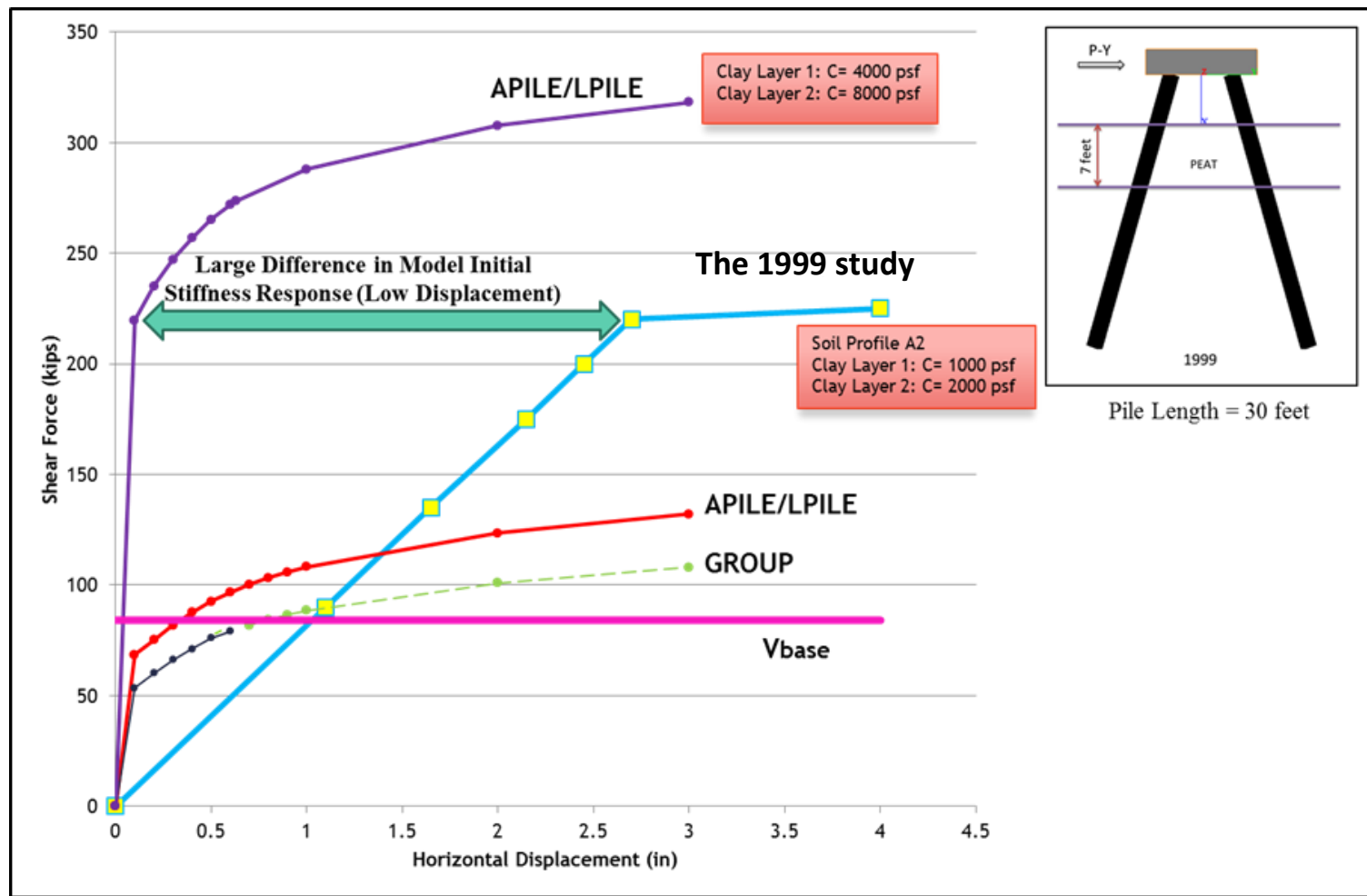

Figure 22. Region 3, matching the ultimate axial/uplift capacity assumptions in the 1999 study by EBMUD's consultant with the APILE/LPILE analysis. Data from the 1999 study are adapted from Aqueduct No. 3 Seismic Upgrade by EBMUD's consultant, 1999.

Based on the current analyses, the 1999 study utilized subsurface profile that was unreasonably simplified. This oversimplification of the profile led to unrealistically high ultimate axial and uplift capacities, as well as inaccurate stiffness estimations. 
Region 4: Middle River to Holt. The evaluation of the subsidence impact on the ultimate lateral capacity of the pile group was investigated in Region 4. Two different soil profiles considered in this evaluation:

- The 1999 study: Soil profile A2 (Table 10)

- AECOM study: Boring log DT-B13-2016 (Table 11)

At this location, the maximum ground acceleration during earthquake shaking is calculated to be $0.37 \mathrm{~g}$, and the maximum expected lateral load at the pile cap is calculated to be 77 kips.

APILE/LPILE analysis and GROUP analysis were performed, and soil profile A2 was considered with a 6-foot peat layer in 1999, a 2.5-foot peat layer in 2017, and no peat layer in the future. Results were compared to the maximum base shear and the lateral load at the 1-inch horizontal deflection of the pile cap. Figure 23 and Figure 24 present APILE/LPILE analyses and GROUP analyses for different peat layer thickness. The analysis shows that the ultimate lateral capacity decreases over time due to the loss of lateral soil support from the peat layer against the piles and pile caps. 
Table 10

The 1999 Study by EBMUD's Consultant: Soil Profile A2 (Middle River to Holt)

\begin{tabular}{|c|c|l|l|c|c|c|}
\hline Layer No. & Depth (ft) & \multicolumn{2}{|c|}{ Description } & Unit Weight (pcf) & Friction Angle (degree) & Cohesion (psf) \\
\hline 1 & $0-6$ & Holocene peat & Peat & 75 & 0 & 100 \\
\hline 2 & $6-23$ & Holocene alluvium & Lean clay & 100 & 0 & 1000 \\
\hline 3 & $23-50$ & Pleistocene alluvium & Lean clay & 100 & 0 & 2000 \\
\hline
\end{tabular}

Note. Adapted from Aqueduct No. 3 Seismic Upgrade by EBMUD’s consultant, 1999.

Table 11

AECOM Study: Boring Log DT-B13-2016 (Middle River to Holt)

\begin{tabular}{|c|c|l|c|c|c|c|}
\hline Layer No. & Depth (ft) & Description & Unit Weight (pcf) & Friction Angle (degree) & Cohesion (psf) & Nq \\
\hline 1 & $0-1.5$ & Fill & 110 & 30 & 0 & 100 \\
\hline 2 & $1.5-4$ & Peat & 75 & 0 & 500 & \\
\hline 3 & $4-13$ & Lean clay & 100 & 0 & 1000 & 0 \\
\hline 4 & $13-19.5$ & Lean clay & 100 & 0 & 47.6 \\
\hline 5 & $19.5-39.5$ & Sand & 120 & 0 & 2000 & \\
\hline 6 & $39.5-50$ & Fat clay & 100 & 0 & & \\
\hline
\end{tabular}

Note. Adapted from Phase 1 Geotechnical Exploration Program-Delta Tunnel Project (GDR) by AECOM, 2017. 


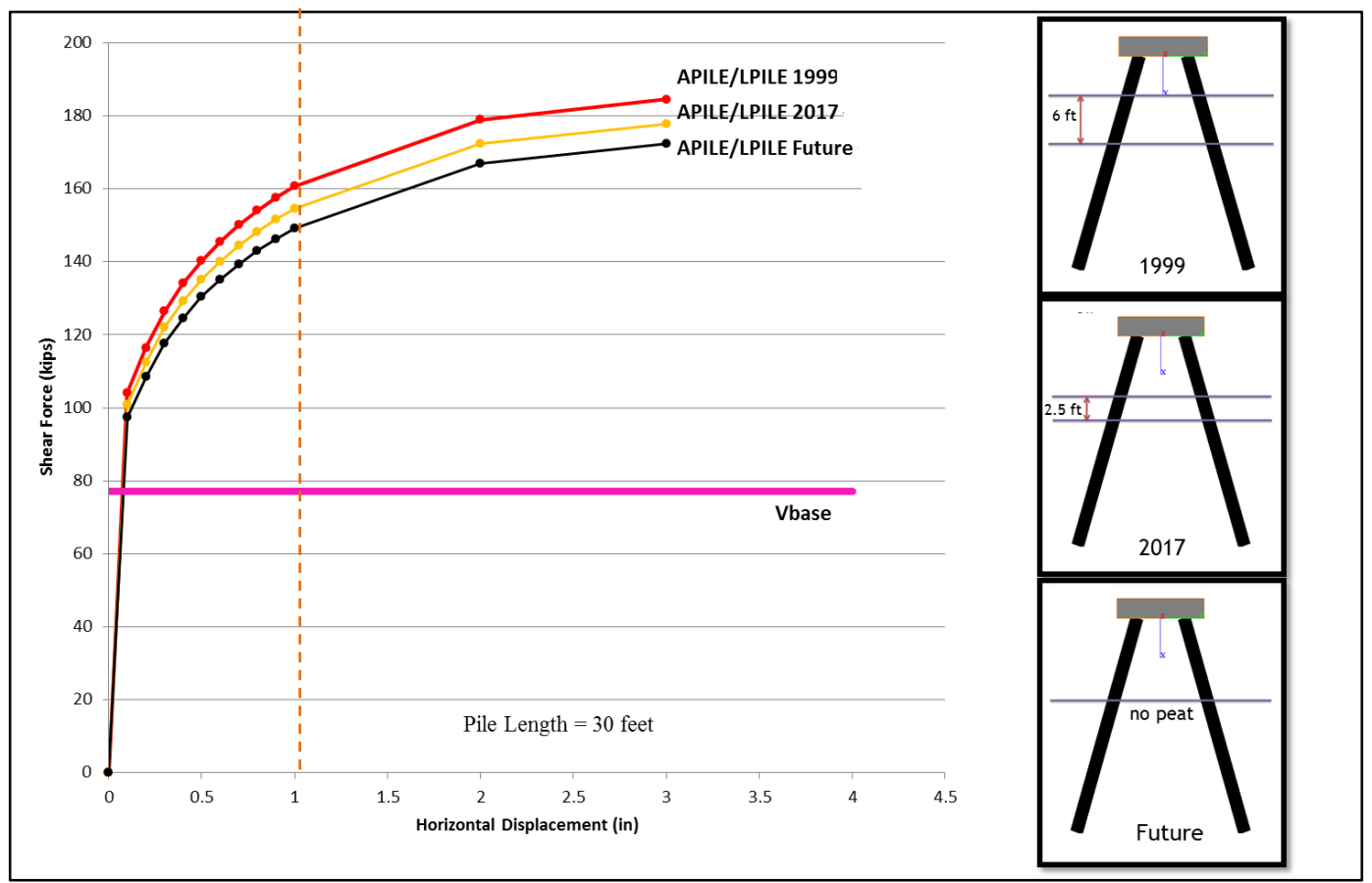

Figure 23. Region 4, evaluation of subsidence impact (APILE/LPILE analysis). The data are adapted from Aqueduct No. 3 Seismic Upgrade by EBMUD's consultant, 1999.

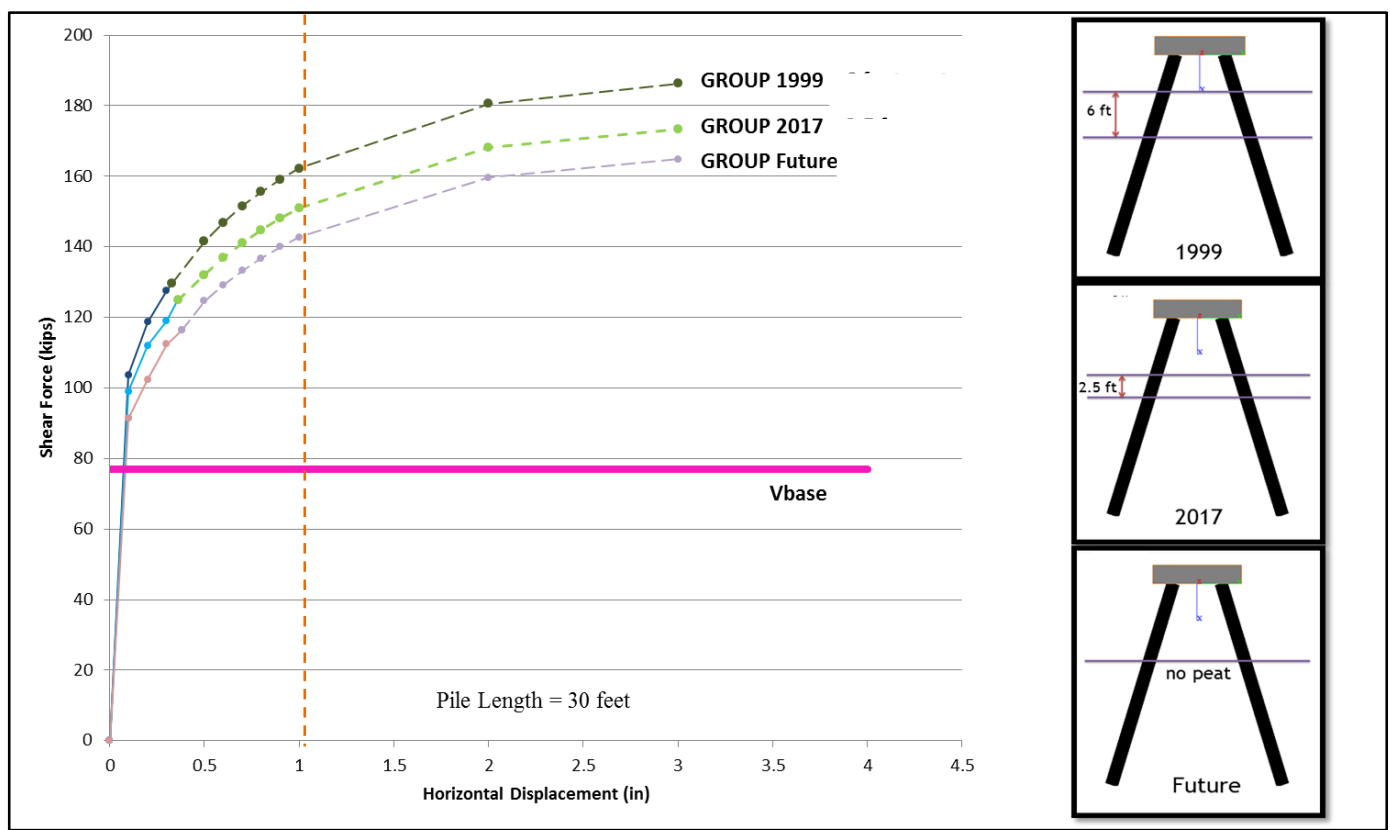

Figure 24. Region 4, evaluation of subsidence impact (GROUP analysis). The data are adapted from Aqueduct No. 3 Seismic Upgrade by EBMUD's consultant, 1999. 
In addition, APILE/LPILE and GROUP analyses were completed using the soil profile determined from the AECOM boring log with a 2.5 -foot peat layer. Results were compared to APILE/LPILE and GROUP analyses results by considering soil profile A2 with a 2.5 -foot peat layer. The ultimate lateral capacities are compared to the maximum base shear and the lateral load at the 1-inch horizontal deflection of the pile cap (Figure 25).

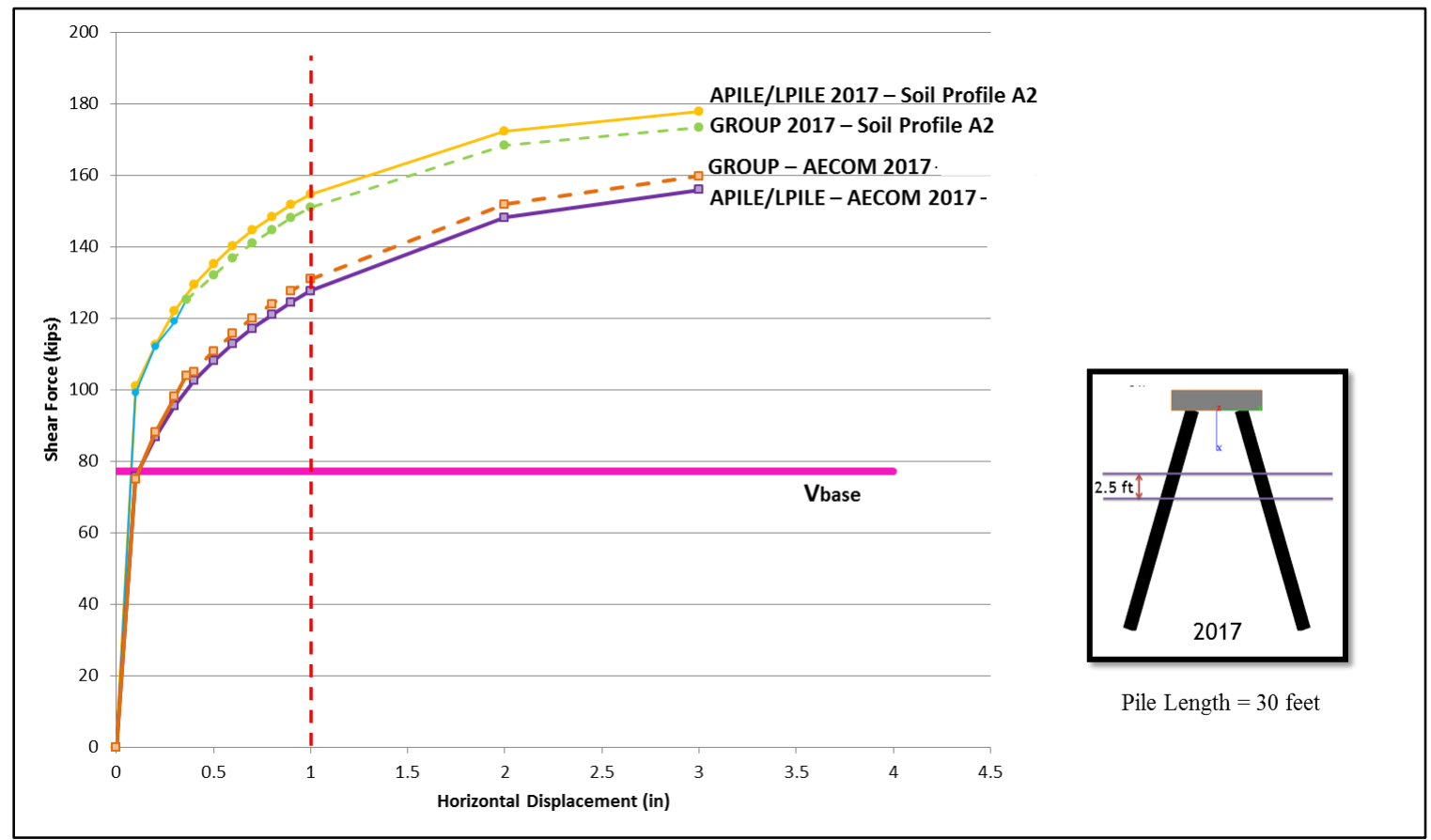

Figure 25. Region 4, APILE/LPILE and GROUP analyses (present condition). The data are adapted from Aqueduct No. 3 Seismic Upgrade by EBMUD's consultant, 1999, and Phase 1 Geotechnical Exploration Program-Delta Tunnel Project (GDR) by AECOM, 2017. 
Region 1: Bixler to Indian Slough. The impact of liquefiable soils on the ultimate lateral capacity of pile groups was investigated in Region 1. Two different soil profiles considered in this evaluation:

- $\quad$ The 1999 study: Soil profile A1 (Table 12)

- AECOM study: Boring log DT-B1-2016 (Table 13)

At this location, the maximum ground acceleration during earthquake shaking is estimated to be $0.42 \mathrm{~g}$, and the maximum expected lateral load at pile cap is estimated to be 90 kips. 
Table 12

The 1999 Study by EBMUD's Consultant: Soil Profile Al(Bixler to Indian Slough)

\begin{tabular}{|c|c|l|l|l|c|c|}
\hline Layer No. & Depth (ft) & \multicolumn{2}{|c|}{ Description } & Unit Weight (pcf) & Friction Angle (degree) & Cohesion (psf) \\
\hline 1 & $0-15$ & Holocene alluvium & Lean clay & 100 & 0 & 1000 \\
\hline 2 & $15-50$ & Pleistocene alluvium & Lean clay & 100 & 0 & 2500 \\
\hline
\end{tabular}

Note. Adapted from Aqueduct No. 3 Seismic Upgrade by EBMUD’s consultant, 1999.

Table 13

AECOM Study: Boring Log DT-B1-2016 (Bixler to Indian Slough)

\begin{tabular}{|c|c|l|c|c|c|c|}
\hline Layer No. & Depth $(\mathrm{ft})$ & Description & Unit Weight $(\mathrm{pcf})$ & Friction Angle (degree) & Cohesion (psf) & Nq \\
\hline 1 & $0-1$ & Fill & 110 & 30 & 0 & 100 \\
\hline 2 & $1-7$ & Peat & 75 & 0 & 2000 & 0 \\
\hline 3 & $7-8$ & Lean clay & 100 & 0 & 27.0 \\
\hline 4 & $8-12$ & Sand & 120 & 32 & 0 & 47.6 \\
\hline 5 & $12-17$ & Liquefiable sand & \multicolumn{2}{|c|}{ taken as very soft clay with C=300 psf and Ko = 1.1} \\
\hline 6 & $17-34$ & Sand & 120 & 35 & 3000 & 0 \\
\hline 7 & $34-46$ & Lean clay & 100 & 0 & & 300 \\
\hline
\end{tabular}

Not Observed

Note. Adapted from Phase 1 Geotechnical Exploration Program-Delta Tunnel Project (GDR) by AECOM, 2017. 
In order to model the liquefiable layer, the equivalent residual strength of liquefiable sand is needed. Seed and Harder (1999) developed a relationship between residual strength and an equivalent clean-sand SPT resistance (see Appendix C, Figure C10). The equivalent clean-sand SPT resistance equation is (Kramer, 1996)

$\left(\mathrm{N}_{1}\right)_{60-\mathrm{cs}}=\left(\mathrm{N}_{1}\right)_{60}+\mathrm{N}_{\text {corr }}$

(Equation 1)

Seed and Harder recommended a fines correction $\left(\mathrm{N}_{\text {corr }}\right)$ for the estimation of residual undrained strength (see Appendix C, Table C2). The corrected SPT N-value equation is (California Department of Transportation, 2014) $\left(\mathrm{N}_{1}\right)_{60}=\mathrm{N}_{\mathrm{m}} \mathrm{C}_{\mathrm{N}} \mathrm{C}_{\mathrm{E}} \mathrm{C}_{\mathrm{B}} \mathrm{C}_{\mathrm{R}} \mathrm{C}_{\mathrm{S}}$ (Equation 2) Appendix C, Table C3 provides parameters to calculate $\left(\mathrm{N}_{1}\right)_{60}$. Based on these calculations, the residual undrained shear strength of the liquefiable layer is $300 \mathrm{psf}$.

The APILE/LPILE and GROUP analyses were completed using soil profile A1 with no peat layer in 1999 and the soil profile determined from the AECOM boring log with a 6-foot peat layer and a 5-foot liquefiable layer. Ultimate lateral capacities were compared with the maximum base shear and the lateral load at the 1-inch horizontal deflection of the pile cap (Figure 26). It is evident that not considering the liquefiable soil in the 1999 study had a considerable impact on the ultimate capacity of the pile group. 


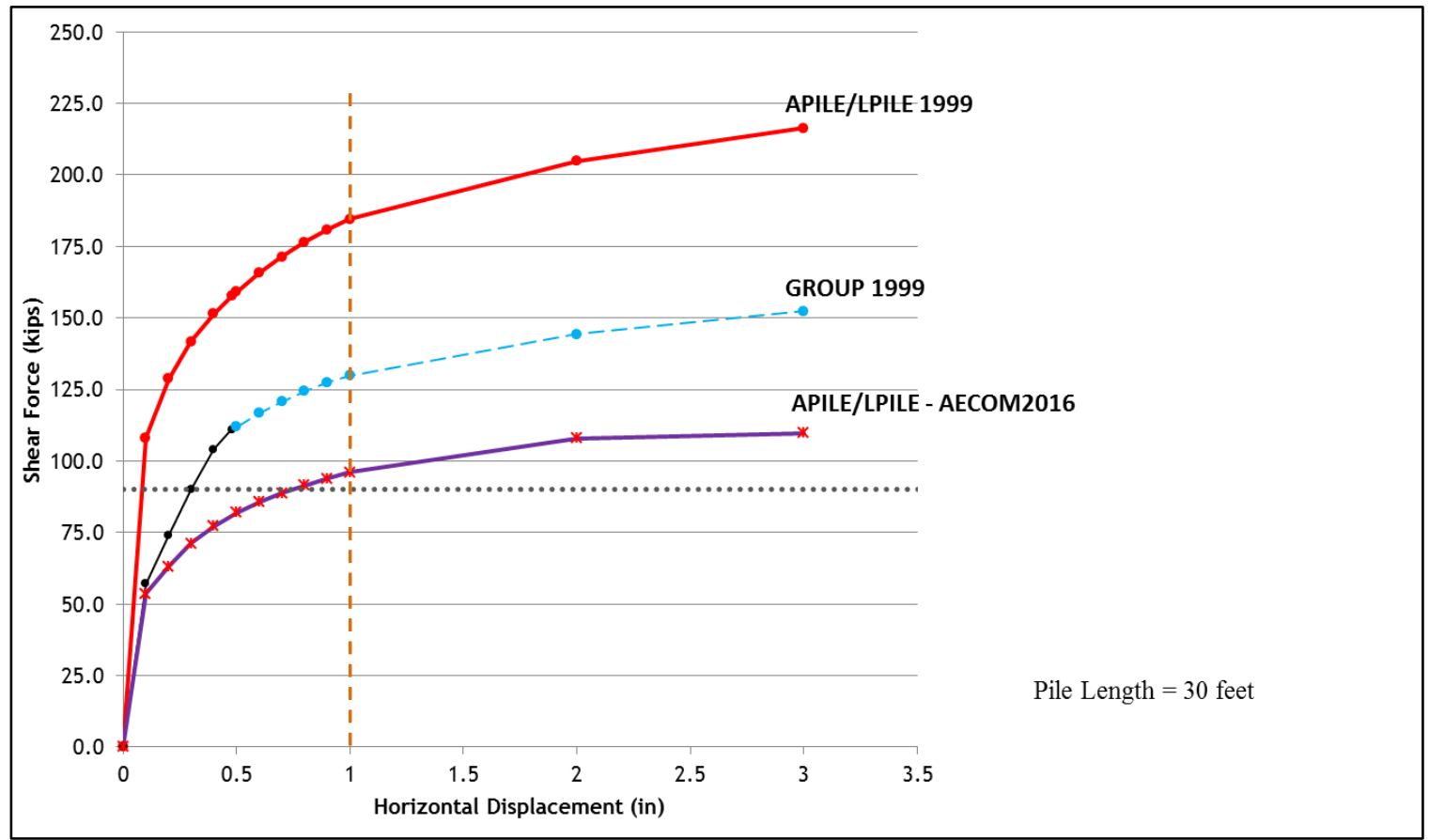

Figure 26. Region 1, evaluation of liquefiable subsurface impact (APILE/LPILE and GROUP analyses). The data are adapted from Aqueduct No. 3 Seismic Upgrade by EBMUD's consultant, 1999, and Phase 1 Geotechnical Exploration Program-Delta Tunnel Project (GDR) by AECOM, 2017.

Region 2: Indian Slough to Old River. The second evaluation of the liquefiable subsurface impact on the ultimate lateral capacity of the pile group was investigated in Region 2. Two different soil profiles considered in this evaluation:

- $\quad$ The 1999 study: Soil profile A1 (Table 14)

- AECOM study: Boring log DT-B4-2016 (Table 15)

At this location, the maximum ground acceleration during earthquake shaking is calculated to be $0.40 \mathrm{~g}$, and the maximum expected lateral load at the pile cap is calculated to be 87 kips. 
Table 14

The 1999 Study by EBMUD's Consultant: Soil Profile A1 (Indian Slough to Old River)

\begin{tabular}{|c|c|l|l|c|c|c|}
\hline Layer No. & Depth (ft) & \multicolumn{2}{|c|}{ Description } & Unit Weight (pcf) & Friction Angle (degree) & Cohesion (psf) \\
\hline 1 & $0-15$ & Holocene alluvium & Lean clay & 100 & 0 & 1000 \\
\hline 2 & $15-50$ & Pleistocene alluvium & Lean clay & 100 & 0 & 2500 \\
\hline
\end{tabular}

Note. Adapted from Aqueduct No. 3 Seismic Upgrade by EBMUD’s consultant, 1999.

Table 15

AECOM Study: Boring Log DT-B4-2016 (Indian Slough to Old River)

\begin{tabular}{|c|c|l|c|c|c|c|}
\hline Layer No. & Depth $(\mathrm{ft})$ & Description & Unit Weight (pcf) & Friction Angle (degree) & Cohesion (psf) & Nq \\
\hline 1 & $0-1$ & Fill & 110 & 30 & 0 & \\
\hline 2 & $1-9$ & Peat & 75 & 0 & 100 \\
\hline 3 & $9-12$ & Lean clay & 100 & 0 & 1000 \\
\hline 4 & $12-25$ & Liquefiable sand & \multicolumn{2}{|c|}{ taken as very soft clay with C $=300$ psf and Ko $=1.1$} \\
\hline 5 & $25-43$ & Sand & 120 & 35 & 0 & 47.6 \\
\hline 6 & $43-50$ & Lean clay & 100 & 0 & 3000 & \\
\hline
\end{tabular}

Note. Adapted from Phase 1 Geotechnical Exploration Program-Delta Tunnel Project (GDR) by AECOM, 2017. 
The APILE/LPILE and GROUP analyses were completed considering soil profile A1 with no peat layer in 1999 and the soil profile determined from the AECOM boring log with an 8-foot peat layer and a 13-foot liquefiable layer. Ultimate lateral capacities are compared with the maximum base shear and the lateral load at the 1-inch horizontal deflection of the pile cap (Figure 27). It is evident that not considering the liquefiable soil in the 1999 study had a considerable impact on the ultimate capacity of the pile group.

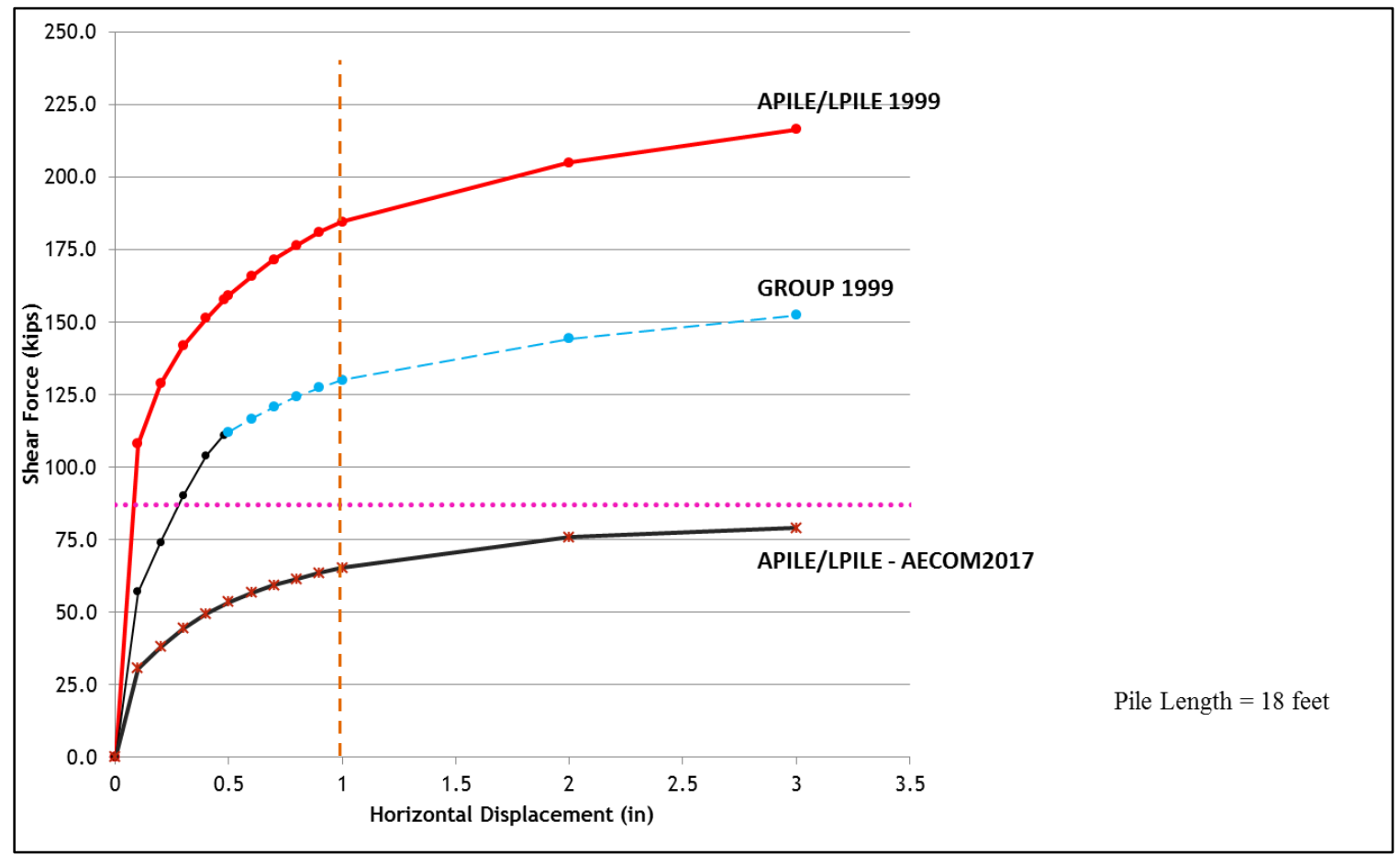

Figure 27. Region 2, evaluation of liquefiable subsurface impact (APILE/LPILE and GROUP analyses). The data are adapted from Aqueduct No. 3 Seismic Upgrade by EBMUD's consultant, 1999, and Phase 1 Geotechnical Exploration Program-Delta Tunnel Project (GDR) by AECOM, 2017. 
Surface geology significantly influences the amplitude, frequency, and duration of seismic motions at the ground surface. In liquefiable soils, progressive buildup of pore water pressure decreases strength and stiffness, resulting in large bending moments and shear forces on the pile and in settlement and tilt of the pile caps and the superstructure.

These analyses show a significant reduction in the piles' lateral and axial capacities caused by the liquefiable soils. In addition to the reduction on lateral support, liquefiable soils may amplify the spectral acceleration of ground motions. Consequently, the maximum expected lateral force that will occur due to seismic ground motion (base shear) increases. As a result, the impact of a liquefied soil may be more significant than what is predicted in this study. A seismic site response analysis is needed to investigate the effect of the liquefiable soil on PGA and $\mathrm{V}_{\text {base }}$ in different regions. AECOM is conducting a site response analysis, which makes the comprehensive evaluation of liquefaction hazards in the Delta feasible. 


\section{Conclusions and Future Studies}

EBMUD has provided interim risk reduction to aqueducts, including a major retrofit of Aqueduct No. 1 in 1990, a seismic upgrade of Aqueduct No. 3 in 2000, and interconnections between the aqueducts on the eastern and western sides of the Delta in 2013. Each project provided a measure of vulnerability reduction.

To minimize the risk of water supply disruption to the East Bay Area before undertaking the preferred long-term protection alternative, EBMUD is developing costeffective short-term alternatives that will improve the reliability of these critical lifelines. This study is quantifying the impact of subsidence and liquefaction on the pile foundations of the Mokelumne Aqueduct in order to develop retrofit alternatives in the future.

A review of the study conducted in 1999 by EBMUD's consultant has led to the following observations:

- Subsurface profiles were unreasonably simplified.

- No potentially liquefiable sand layer was identified in subsurface profiles.

- Unrealistically high ultimate axial and uplift capacities were reported.

The current study utilized subsurface profiles determined from boring logs recently prepared by AECOM. A stability analysis was performed by considering both the 1999 and current soil profiles, and results have been compared. The analysis quantified the impact on pile lateral and axial capacities due to subsidence. Subsidence in the Delta is predicted to reduce the lateral support of the piles, which is critical to reflect in the mitigation plan. Furthermore, pile instability due to identified liquefiable layers has been 
investigated. Analysis shows that liquefaction would lead to a significant reduction in the piles' lateral and axial capacities due to loss of soil shear strength.

The following are observations and recommendations for future work:

1. This study evaluated the stability of BENT I at different regions along the aqueducts' alignment. A stability analysis of temperature anchors, road anchors and bend anchors should also be completed.

2. AECOM is currently conducting seismic and liquefaction studies for the Tunnel Geotechnical Exploration Project. This current study should be improved based on the final results of the soil investigation.

3. In 2000, the Aqueduct No. 3 Seismic Upgrade Project identified base isolators, located between the pipeline and the foundation, as desirable mechanisms to relieve most of the potential destructive earthquake movement that could occur during a seismic event. The impact of base isolators on the stability of Aqueduct No. 3 needs further analysis.

4. Soil collapse due to moisture ingress is a potential hazard. The effects on the lateral stability of the aqueducts as a result of this soil collapse should be assessed.

5. A more comprehensive stability analysis that would capture nonlinear soilstructure interaction utilizing FEA modeling would provide more reliable results.

6. Comprehensive mitigation plan that is necessary to improve the reliability of critical lifelines. 


\section{References}

AECOM. (2017a). Delta tunnel seismic study report- Phase 1. Oakland, CA: EBMUD Archives.

AECOM. (2017b). Phase 1 geotechnical exploration program - Delta tunnel project (GDR). Oakland, CA: EBMUD Archives.

American Concrete Institute. (2014). ACI 318 - 14 Building code requirements for structural concrete and commentary. Cambridge, MA: ACI.

American Society of Civil Engineers. (2010). Minimum design loads for buildings and other structures (7-10). Reston, VA: ASCE.

American Society of Civil Engineers. (2017). Infrastructure in California. Retrieved from https://www.infrastructurereportcard.org/state-item/california/

American Society for Testing and Materials. (1966). ASTM - A15: Specification for steel bars for concrete reinforcement. West Conshohocken, PA: ASTM International.

California Department of Transportation. (2014). Caltrans geotechnical manual. Retrieved from http://www.dot.ca.gov/hq/esc/geotech/geo_manual/page/Embankments_Dec2014.pdf

California Department of Water Resources. (n.d.). Delta overview. Retrieved from http://baydeltaoffice.water.ca.gov/sdb/tbp/deltaoverview/index.cfm

California Department of Water Resources. (2008). Technical memorandum: Delta risk management strategy (DRMS) phase 1- Subsidence. Retrieved from http://www.water.ca.gov/floodmgmt/dsmo/sab/drmsp/docs/Subsidence_TM.pdf

Deverel, S. J., Ingrum, T., \& Leighton, D. A. (2016). Present-day oxidative subsidence of organic soils and mitigation in the Sacramento-San Joaquin Delta. Hydrogeology Journal, 24, 569-586.

EBMUD. (1966; 2010; and 2015). DOX database: Aqueducts' survey data. Oakland, CA: EBMUD Archives.

EBMUD. (1968). DOX database: 4190-G-5.26 \& 5.28. Oakland, CA: EBMUD Archives.

EBMUD. (2013a). All about EBMUD. Retrieved from http://www.ebmud.com/aboutus/publications/

EBMUD. (2013b). EBMUD GIS online mapping center. Retrieved from http://ebmudisd.maps.arcgis.com 
EBMUD's consultant. (1999). Aqueduct No. 3 seismic upgrade. Oakland, CA: EBMUD Archives.

ENSOFT. (2015). APILE (v7): A program for the analysis and design of axially loaded piles. Retrieved from http://www.ensoftinc.com/products/apile/doc/description_sheet.pdf

ENSOFT. (2016a). LPILE (v9): Analysis and design of deep foundations under lateral loads. Retrieved from http://www.ensoftinc.com/products/lpile/doc/description_sheet.pdf

ENSOFT. (2016b). GROUP (v10): A program for the analysis of piles in a Group. Retrieved from http://www.ensoftinc.com/products/group/doc/description_sheet.pdf

Kramer, S. L. (1996). Geotechnical earthquake engineering. Upper Saddle River, NJ: Prentice Hall.

Samtani, N. C. (2017, August 28). Geotechnical Engineering Features Deep Foundations: Lateral Analysis [Webinar]. Retrieved from https://www.asce.org/continuing-education/live-webinars/

Prashar, Y., Irias, X. J., \& Shewbridge, S. E. (2009). East Bay Municipal Utility District's Mokelumne Aqueduct in the Sacramento-San Joaquin Delta: Hazard evaluation. Pipelines 2009: Infrastructure's Hidden Assets, 1263-1275.

United States Geological Survey. (n.d.). EarthExplorer. Retrieved from https://earthexplorer.usgs.gov

United States Geological Survey. (n.d.). US seismic design maps. Retrieved from https://earthquake.usgs.gov/hazards/designmaps/usdesign.php 
Appendices

Appendix A: Structural Features 


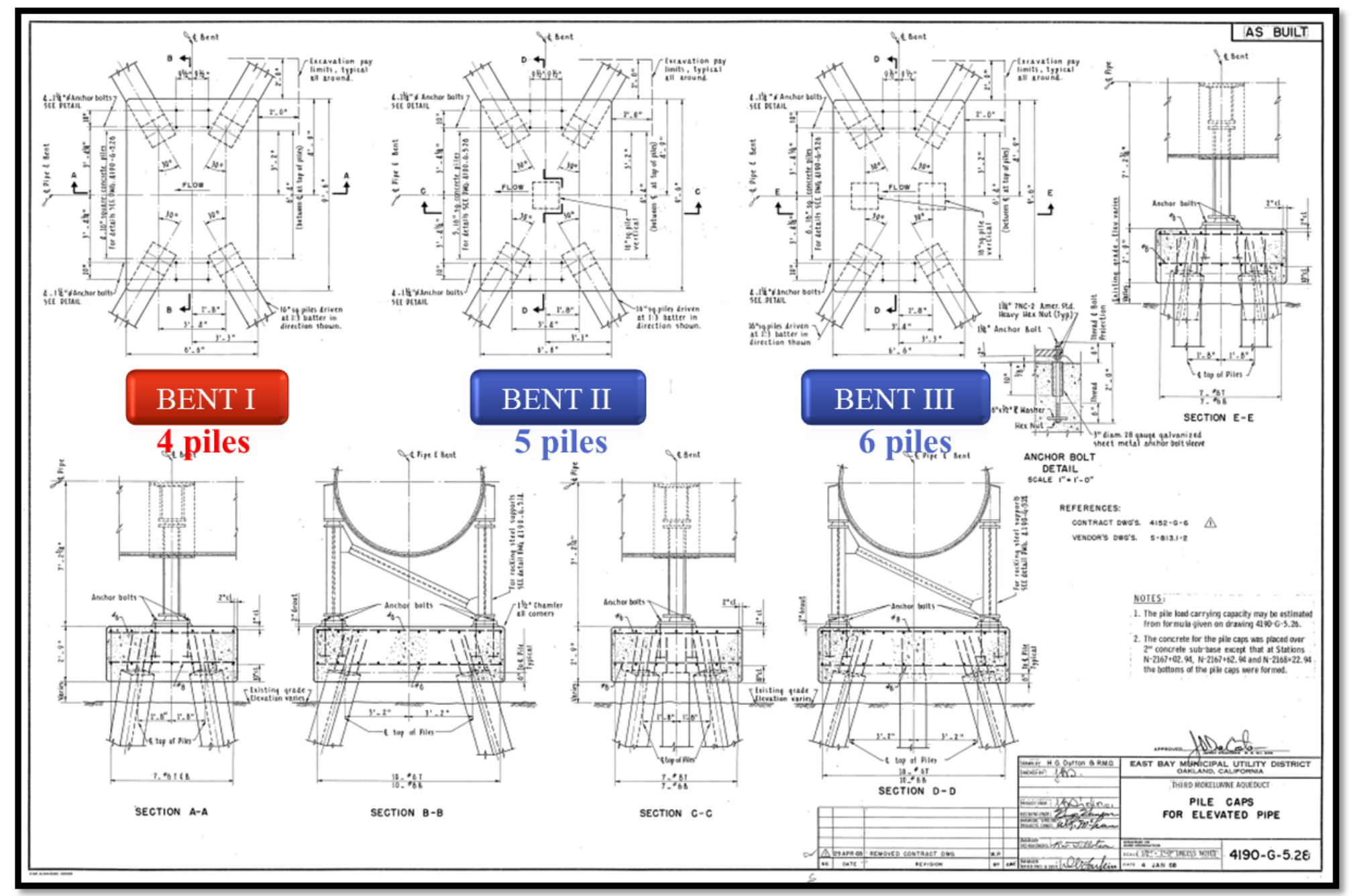

Figure A1. Aqueduct No. 3 pile caps for elevated pipe. East Bay Municipal Utility District DOX Database (4190-G-5.28). Asbuilt drawing, 1968. 


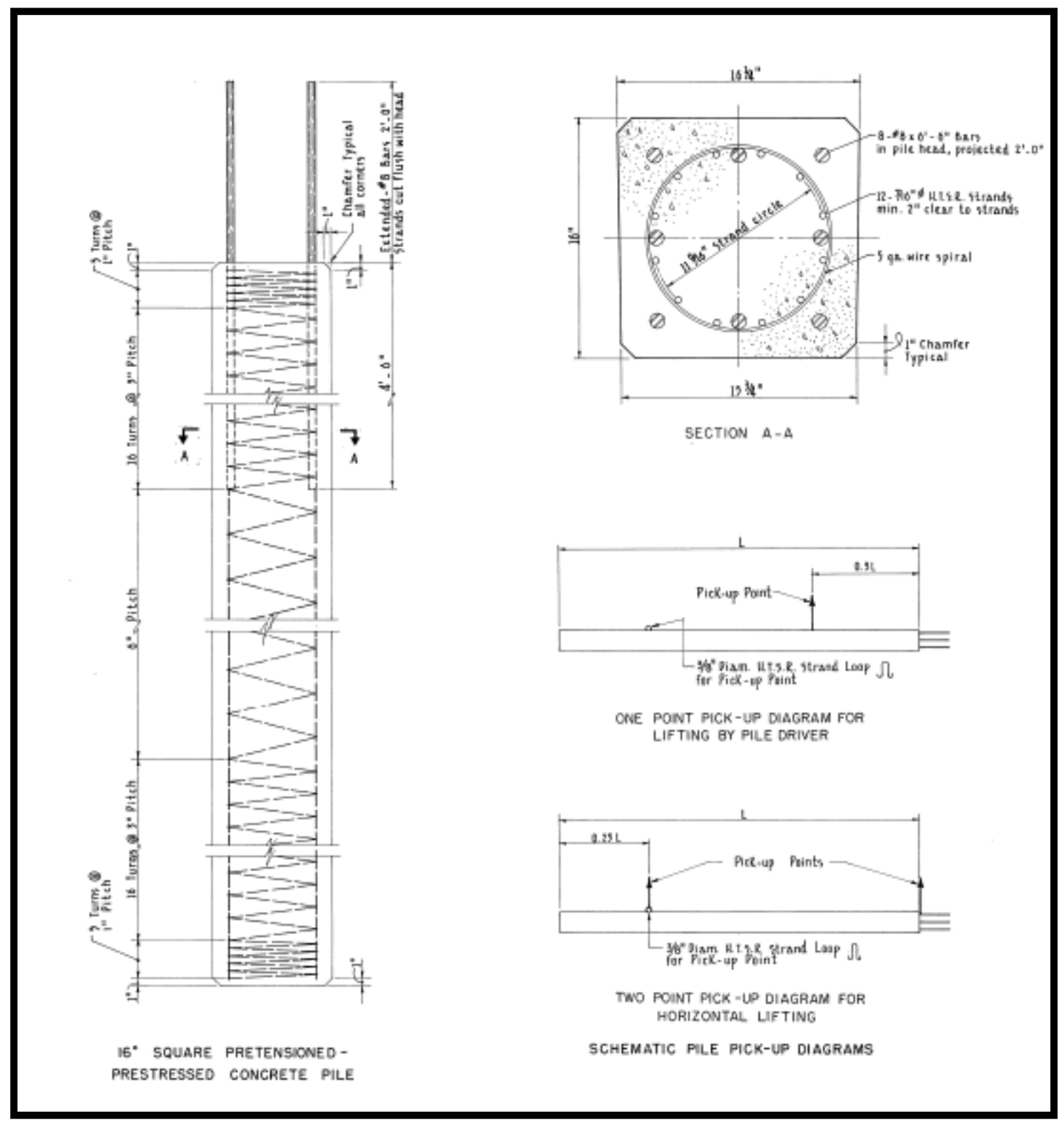

Figure A2. Aqueduct No. 3 concrete pile details. East Bay Municipal Utility District DOX Database (4190-G-5.26). As-built drawing, 1968. 
Table A1

Pre-tensioned Pre-stressed Concrete Pile Properties

\begin{tabular}{|c|c|c|c|}
\hline \multicolumn{2}{|l|}{ Pre-tensioned Pre-stressed Concrete Pile } & \multirow[b]{3}{*}{250} & \multirow[b]{3}{*}{$\mathrm{ksi}$} \\
\hline $16 \times 16$ inch square pil & & & \\
\hline \multirow{7}{*}{ Pre-stressed Steel (ASTM A-416) } & Ultimate strength & & \\
\hline & No. of strands & 12 & \\
\hline & Strand dia. & $7 / 16$ & in \\
\hline & Strand circle dia. & $119 / 16$ & in \\
\hline & Strand cover & 2 & in \\
\hline & Initial pre-stress load (per strand) & 18900 & Ibs \\
\hline & Final working force (per strand) & 15120 & Ibs \\
\hline Pre-stress Force & $\mathrm{T}$ & 709 & psi \\
\hline \multirow{3}{*}{$\begin{array}{l}\text { Longitudinal Bars (Mild Steel) - Pile Cap } \\
\text { Connection ( } 2 \mathrm{ft} \text { into pile cap }+4.5 \mathrm{ft} \\
\text { into pile) }\end{array}$} & Bar No. & 8 & $\#$ \\
\hline & Bar length & 78 & in \\
\hline & Bar dia. & 1 & in \\
\hline \multirow{6}{*}{ Spiral Hoops (ASTM A-82) } & No. of wire & 5 & $\#$ \\
\hline & Section 1 (1 to 6 in depth) & \multicolumn{2}{|c|}{5 turns @ 1"pitch } \\
\hline & \begin{tabular}{|l} 
Section 2 (6 to 54 in depth) \\
\end{tabular} & \multicolumn{2}{|c|}{16 turns@ 3 "pitch } \\
\hline & Section 3 (54 to 306 in depth) & \multicolumn{2}{|c|}{42 turns@6" pitch } \\
\hline & Section 4 (306 to 354 in depth) & \multicolumn{2}{|c|}{16 turns@ 3 " pitch } \\
\hline & Section 5 (354 to 359 in depth) & \multicolumn{2}{|c|}{5 turns@1"pitch } \\
\hline \multirow{3}{*}{ Concrete Strength } & fci (at time of pre-stressing) & 3500 & psi \\
\hline & $\mathrm{fc}$ & 5000 & psi \\
\hline & Cement Type & II & \\
\hline
\end{tabular}

Note. Adapted from Aqueduct No. 3 Seismic Upgrade by EBMUD's consultant, 1999. 
Table A2

Axial Load on Pile Group

\begin{tabular}{|c|c|c|c|}
\hline \multicolumn{4}{|l|}{\begin{tabular}{|l|} 
Aqueduct No. 3 \\
\end{tabular}} \\
\hline \multicolumn{4}{|l|}{ BENT I, II, III } \\
\hline \multicolumn{4}{|l|}{ Pipe } \\
\hline Outside Dia. & O.D. & 89.50 & in \\
\hline Inside Dia. & I.D. & 88.50 & in \\
\hline Pipe thickness & $\mathrm{t}$ & 0.50 & in \\
\hline Modulus of elasticity & Es & 29000 & ksi \\
\hline Moment of inertia & $\mathrm{I}$ & 138424.71 & in $^{4}$ \\
\hline Area & A & 139.8 & in $^{2}$ \\
\hline Steel unit weight & & 490 & $\mathrm{Ib} / \mathrm{ft}^{2}$ \\
\hline \multirow[t]{3}{*}{ Inside mortar } & O.D. & 88.5 & in \\
\hline & I.D. & 87.5 & in \\
\hline & $\mathrm{t}$ & 0.5 & in \\
\hline Area & A & 138.2 & in $^{2}$ \\
\hline Mortar unit weight & & 100 & $\mathrm{Ib} / \mathrm{ft}^{2}$ \\
\hline Approx. weight per ft & $\mathrm{W}$ & 0.57 & kips/ft \\
\hline Pipe length & $\mathrm{L}$ & 60 & $\mathrm{ft}$ \\
\hline Approx. weight & $\mathrm{W}$ & 34.30 & kips \\
\hline \multirow[t]{6}{*}{ BENT } & Length & 174 & in \\
\hline & Weight per $\mathrm{ft}$ & 0.045 & $\mathrm{kips} / \mathrm{ft}$ \\
\hline & Length & 120 & in \\
\hline & Weight per ft & 0.1 & kips/ft \\
\hline & Length & 96 & in \\
\hline & Weight per ft & 0.017 & kips/ft \\
\hline Approx. weight & $\mathrm{W}$ & 1.79 & kips \\
\hline \multirow[t]{3}{*}{ Pile Cap } & Length & 114 & in \\
\hline & Width & 78 & in \\
\hline & Height & 33 & in \\
\hline Approx. weight & $\mathrm{W}$ & 25.47 & kips \\
\hline \multicolumn{4}{|l|}{ Water } \\
\hline Approx. weight per ft & $\mathrm{W}$ & 2.67 & kips/ft \\
\hline Pipe length & $\mathrm{L}$ & 60 & $\mathrm{ft}$ \\
\hline Approx. weight & $\mathrm{W}$ & 159.94 & kips \\
\hline Total weight & & 221.5 & kips \\
\hline Total weight + seismic vertical force & & 252.1 & kips \\
\hline $1.2 \mathrm{DL}$ & & 302.5 & kips \\
\hline
\end{tabular}


Table A3

Development Length for Deformed Bars and Deformed Wires in Tension

Table 25.4.2.2-Development length for deformed bars and deformed wires in tension

\begin{tabular}{|c|c|c|}
\hline Spacing and cover & $\begin{array}{c}\text { No. } 6 \text { and } \\
\text { smaller bars and } \\
\text { deformed wires }\end{array}$ & $\begin{array}{l}\text { No. } 7 \text { and } \\
\text { larger bars }\end{array}$ \\
\hline $\begin{array}{l}\text { Clear spacing of bars or wires being } \\
\text { developed or lap spliced not less } \\
\text { than } d_{b} \text {, clear cover at least } d_{b} \text {, and } \\
\text { stimups or ties throughout } \ell_{d} \text { not less } \\
\text { than the Code minimum } \\
\text { or } \\
\text { Clear spacing of bars or wires being } \\
\text { developed or lap spliced at least } 2 d_{b} \\
\text { and clear cover at least } d_{b}\end{array}$ & $\left(\frac{f_{y} \psi_{t} \psi_{c}}{25 \lambda \sqrt{f_{c}^{\prime}}}\right) d_{b}$ & $\left(\frac{f_{y} \psi_{t} \psi_{c}}{20 \lambda \sqrt{f_{c}^{\prime}}}\right) d_{t}$ \\
\hline Other cases & $\left(\frac{3 f_{,} \psi_{t} \psi_{c}}{50 \lambda \sqrt{f_{c}^{\prime}}}\right) d_{s}$ & $\left(\frac{3 f_{y} \psi_{t} \psi_{c}}{40 \lambda \sqrt{f_{c}^{\prime}}}\right) d_{b}$ \\
\hline
\end{tabular}

Note. Retrieved from Building Code Requirements for Structural Concrete (ACI $318-$ 14) by American Concrete Institute (ACI), 2014.

Table A4

Parameters to Calculate Development Length for Bars

\begin{tabular}{|c|c|l|}
\hline Parameters & Value & \multicolumn{1}{|c|}{ Description } \\
\hline$\Psi \mathrm{t}$ & 1 & Larger bottom bars \\
\hline$\Psi \mathrm{e}$ & 1 & Uncoated reinforcement \\
\hline$\lambda$ & 1 & Normal weight concrete \\
\hline fy (psi) & 33000 & Yield strength (ASTM spec - A15) \\
\hline fy (psi) & 40000 & Year 1911 to 1966 \\
\hline f'c (psi) & 4000 & Concrete compressive strength \\
\hline $\mathrm{d}_{\mathrm{b}}$ (in) & 1 & $\#$ 8 rebar diameter \\
\hline
\end{tabular}

Note. Adapted from Building Code Requirements for Structural Concrete (ACI 318 - 14) by American Concrete Institute (ACI), 2014, and ASTM - A15 by American Society for Testing and Materials (ASTM), 1966. 
Appendix B: Seismic Study 


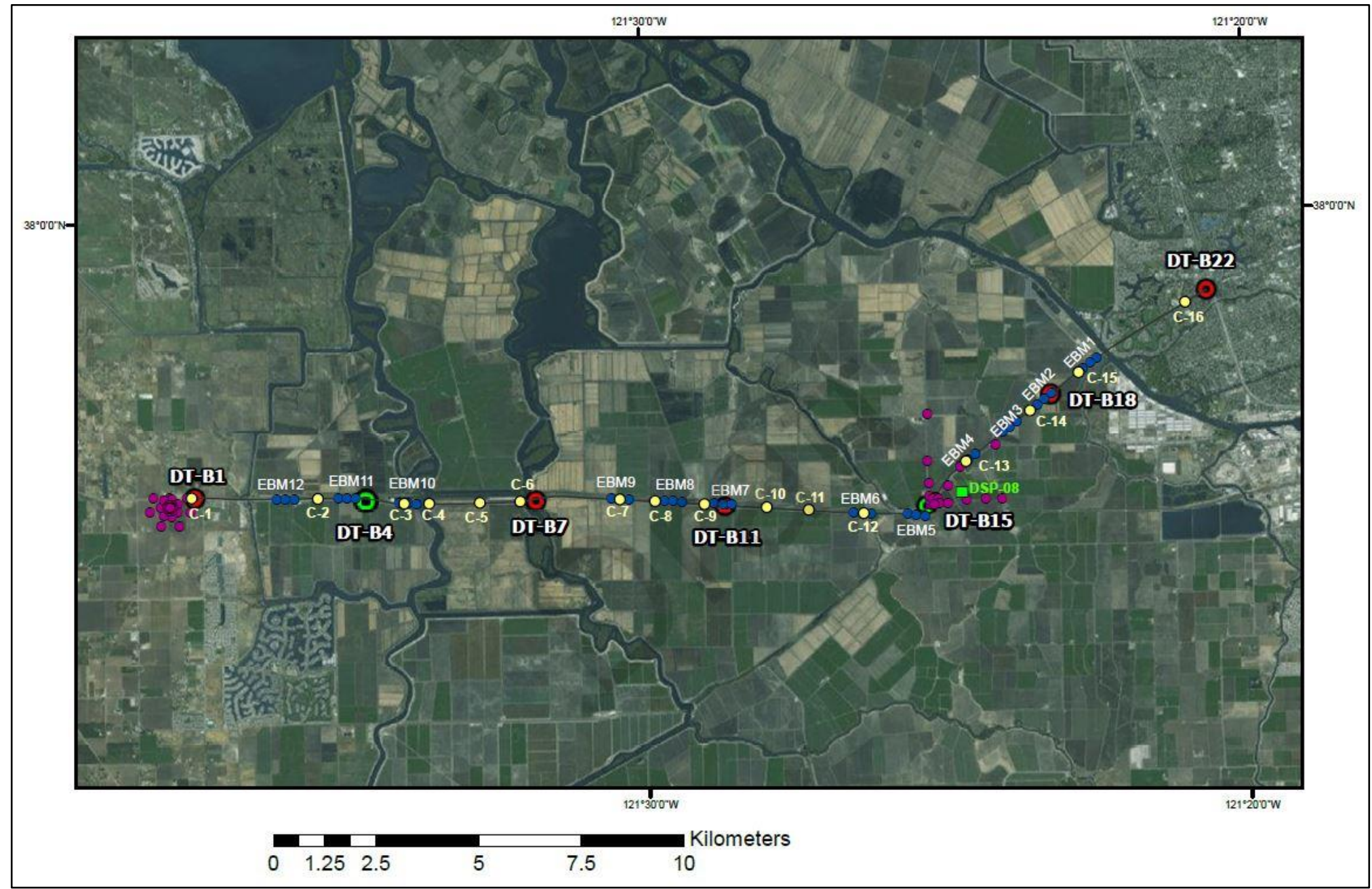

Figure B1. Selected boring logs for PGA determination. Adapted from the Delta Tunnel Seismic Study Report - Phase 1 by AECOM, 2017. 


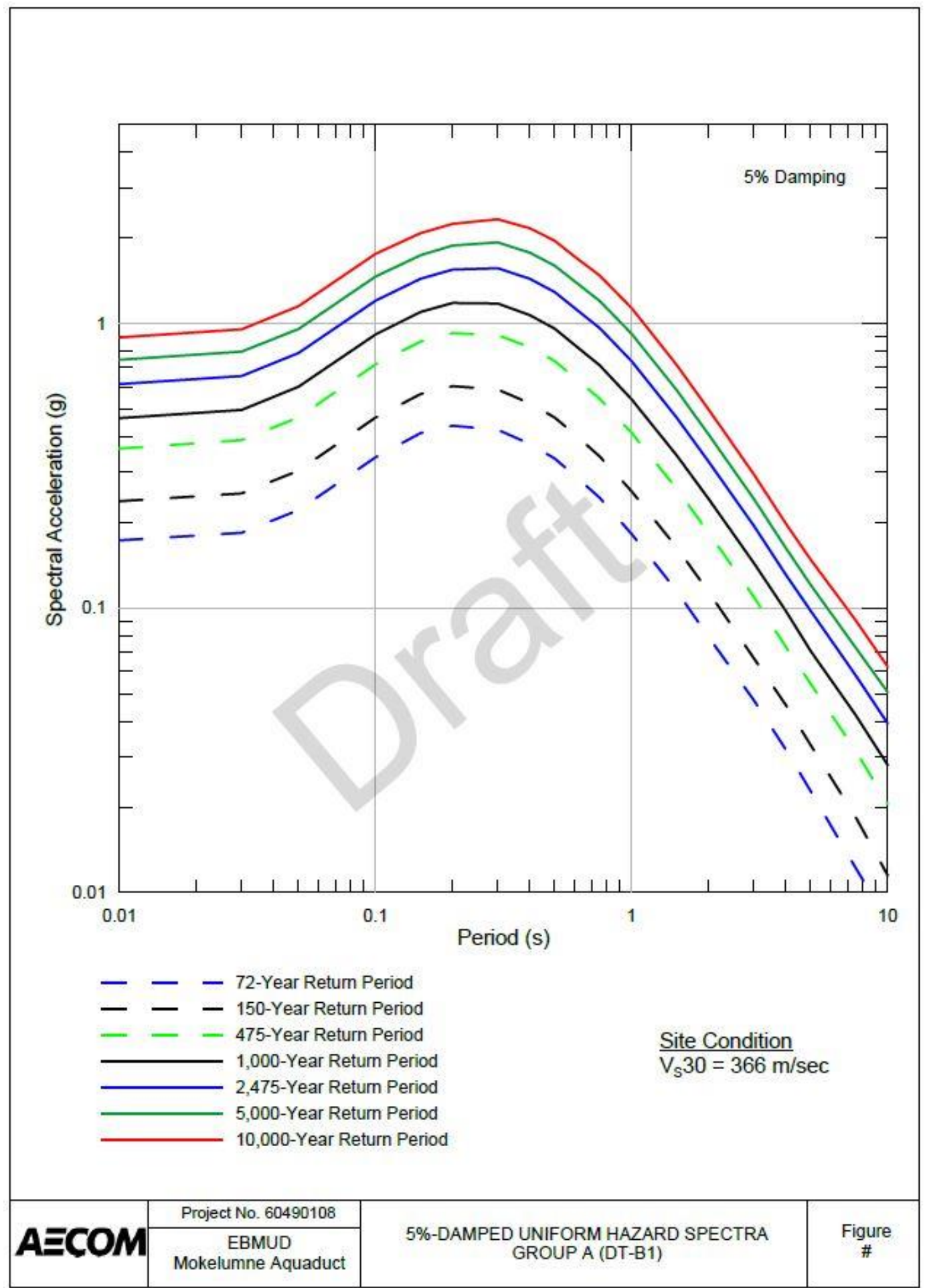

Figure B2. Region 1, PGA determination. Adapted from Delta Tunnel Seismic Study Report-Phase 1 by AECOM, 2017. 


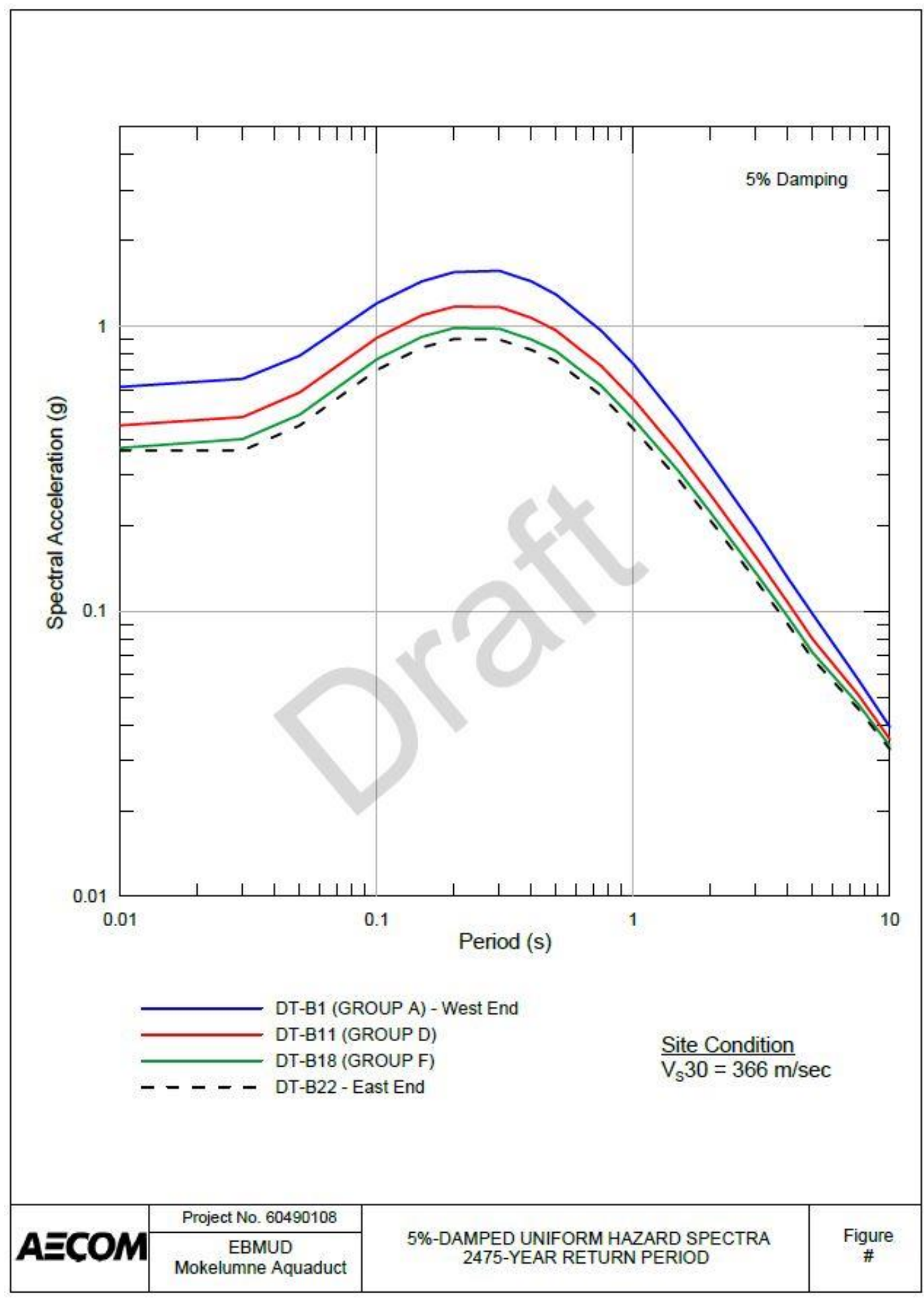

Figure B3. Region 4, PGA determination. Adapted from Delta Tunnel Seismic Study Report-Phase 1 by AECOM, 2017. 
Table B1

References and Parameters for Determination of Base Shear

\begin{tabular}{|l|c|}
\hline Source & USGS website \\
\hline Reference & ASCE 7-10 (ch15) \\
\hline Structure Type & Rigid nonbuilding structure \\
\hline Time Period & $\mathrm{T}<0.06$ \\
\hline Site Class & $\mathrm{E}$ \\
\hline Risk Category & $\mathrm{IV}$ \\
\hline Importance Factor $\left(\mathrm{I}_{\mathrm{e}}\right)$ & 1.25 \\
\hline $\mathrm{S}_{\mathrm{ds}}$ & Variable at 4 regions \\
\hline $\mathrm{W}_{\text {bent }}$ (kips) & 300 \\
\hline $\mathrm{V}_{\text {base }}$ & $0.3 \mathrm{~S}_{\mathrm{ds}} \mathrm{W}_{\text {bent }} \mathrm{I}_{\mathrm{e}}$ \\
\hline
\end{tabular}

Note. The data are adapted from "U.S. Seismic Design Maps" from the United States Geological Survey (n.d.), and ASCE 7-10: Minimum Design Loads for Buildings and Other Structures (chapter 15) by the American Society of Civil Engineers, 2010. 
Appendix C: Stability Analysis 
Table $\mathrm{C} 1$

The 1999 Study by EBMUD's Consultant: Ultimate Axial and Uplift Capacities Assumption

\begin{tabular}{|c|c|c|c|}
\hline Station & $\begin{array}{c}\text { Ultimate } \\
\text { Axial } \\
\text { Capacity } \\
\text { (Kips) }\end{array}$ & $\begin{array}{c}\text { Ultimate } \\
\text { Toe } \\
\text { Capacity } \\
\text { (Kips) }\end{array}$ & $\begin{array}{c}\text { Ultimate } \\
\text { Uplift } \\
\text { Capacity } \\
\text { Kips }\end{array}$ \\
\hline 2150 & 240 & 130 & 110 \\
2178 & 260 & 120 & 140 \\
2230 & 260 & 120 & 140 \\
2280 & 330 & 120 & 110 \\
2329 & 300 & 150 & 150 \\
2379 & 190 & 130 & 60 \\
2438 & 180 & 120 & 60 \\
2467 & 210 & 110 & 100 \\
2519 & 165 & 105 & 60 \\
2548 & 205 & 115 & 90 \\
2589 & 225 & 120 & 105 \\
2630 & 220 & 160 & 60 \\
2671 & & & \\
2700 & & & \\
\hline
\end{tabular}

Note. Adapted from Aqueduct No. 3 Seismic Upgrade by EBMUD’s consultant, 1999. 


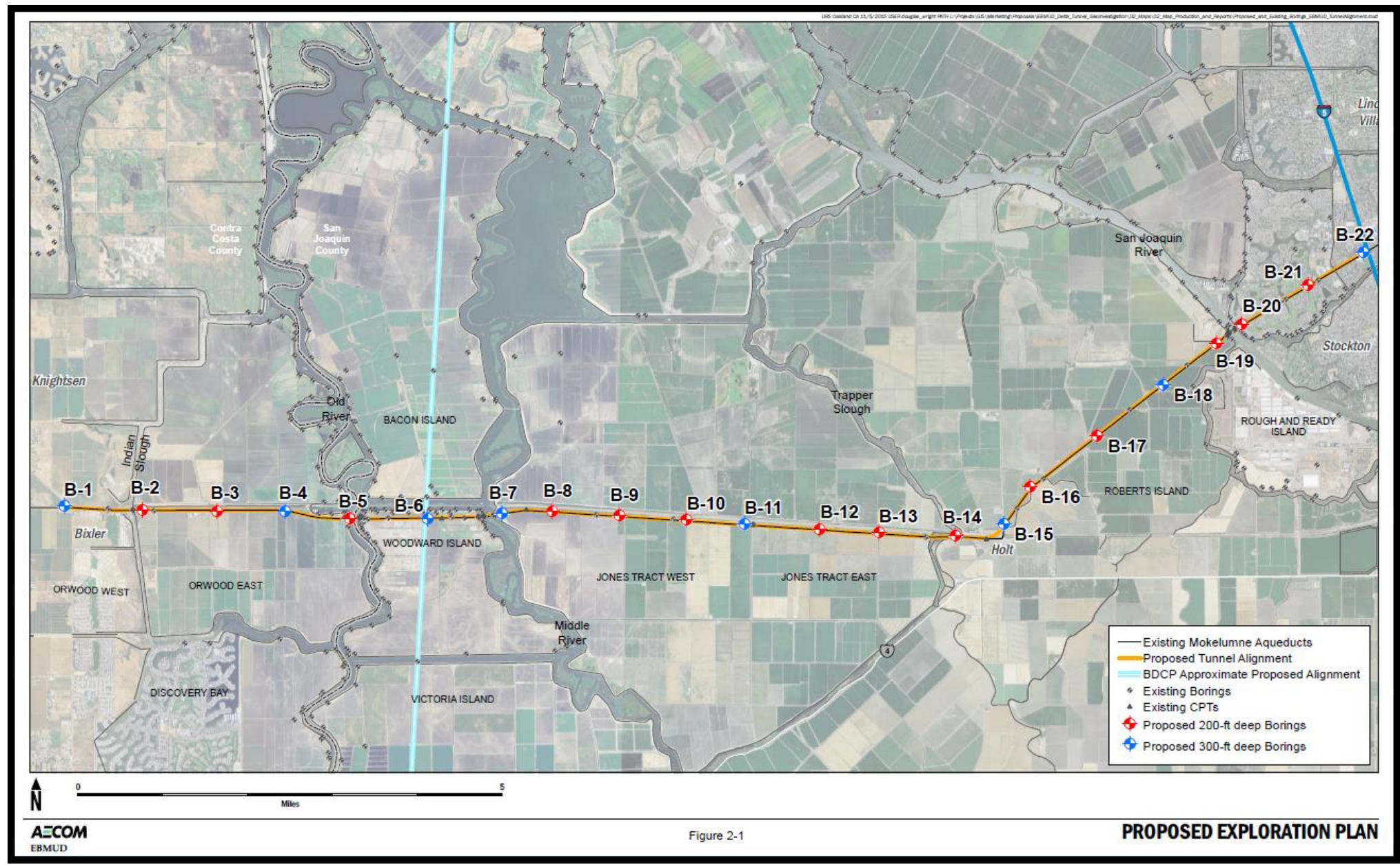

Figure C1. Proposed exploration plan. Adapted from Phase 1 Geotechnical Exploration Program-Delta Tunnel Project $(G D R)$ by AECOM, 2017. 


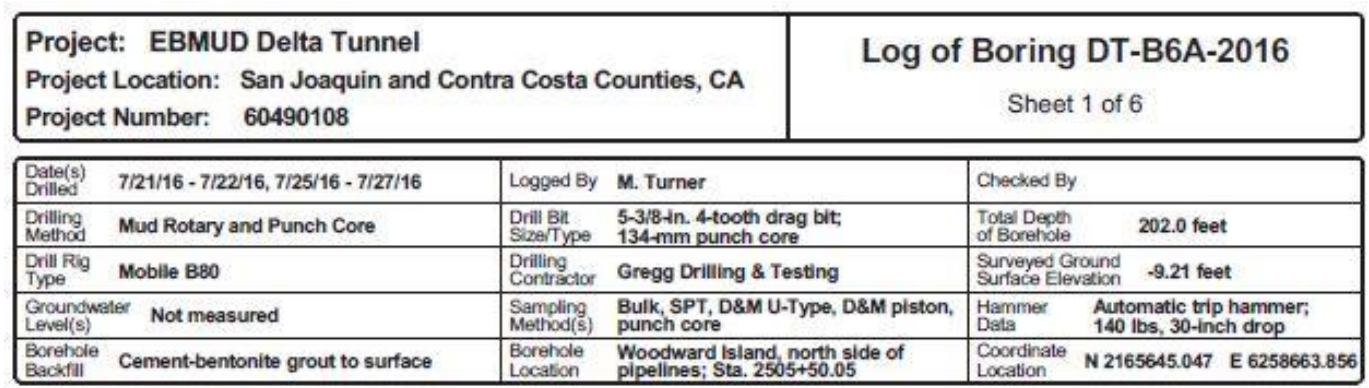

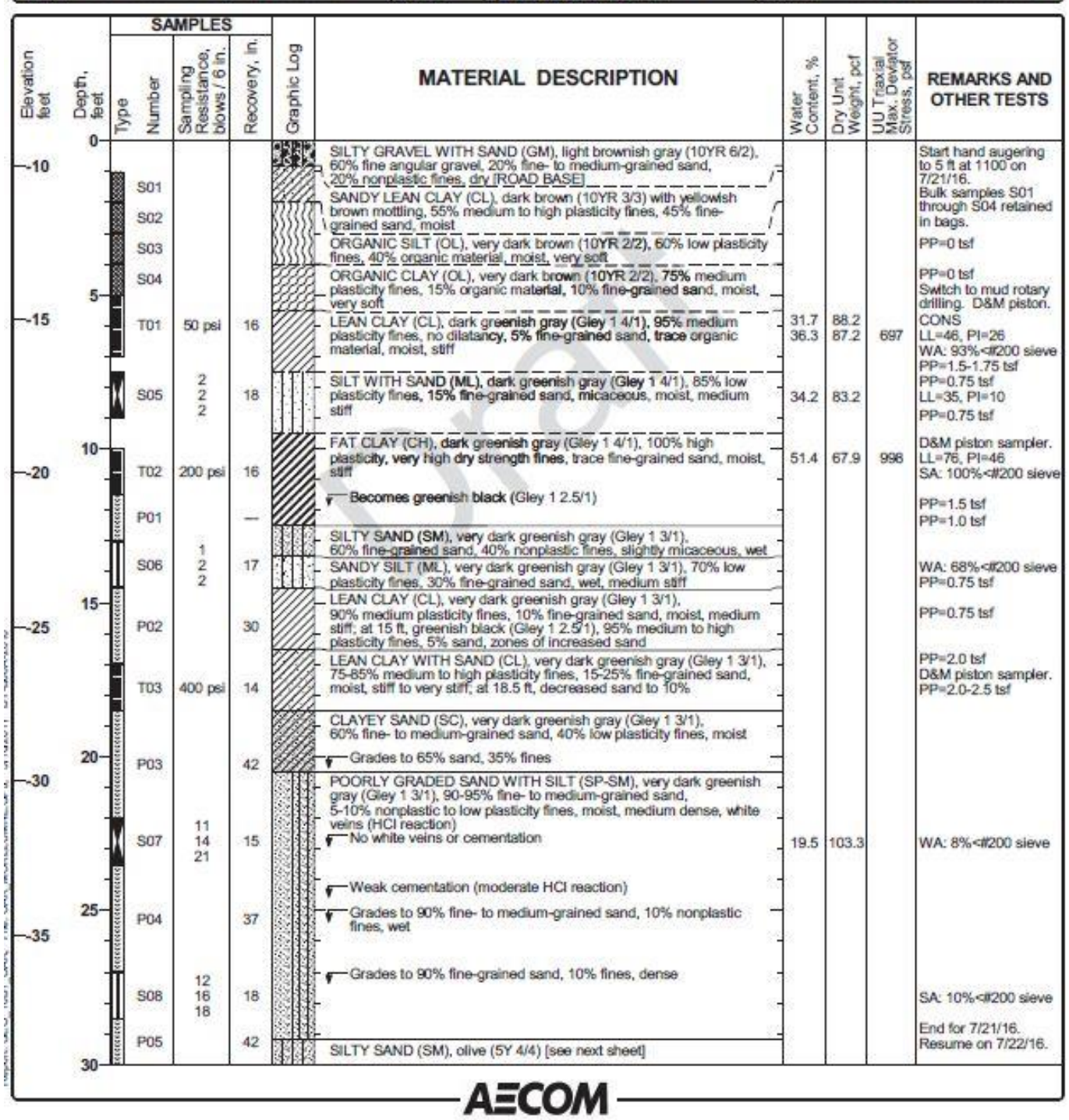

Figure C2. Boring log DT-B6A-2016. Adapted from Phase 1 Geotechnical Exploration Program-Delta Tunnel Project (GDR) by AECOM, 2017. 


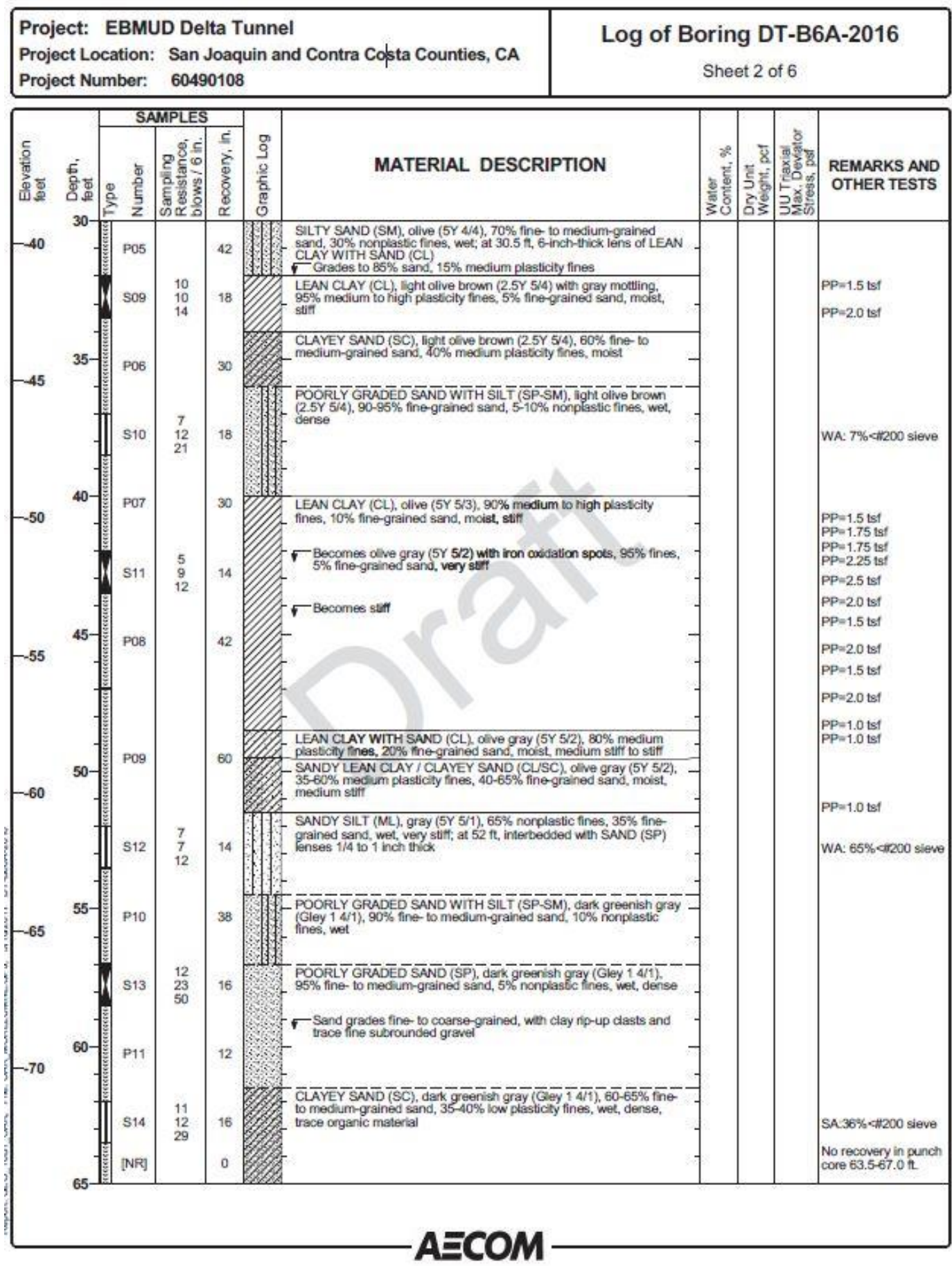

Figure C3. Boring log DT-B6A-2016 continued. Adapted from Phase 1 Geotechnical Exploration Program-Delta Tunnel Project (GDR) by AECOM, 2017. 


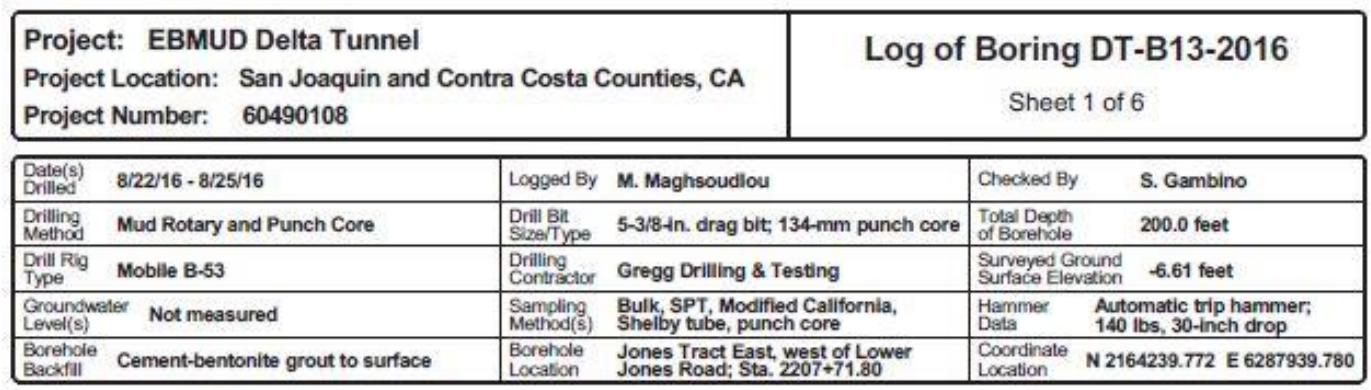

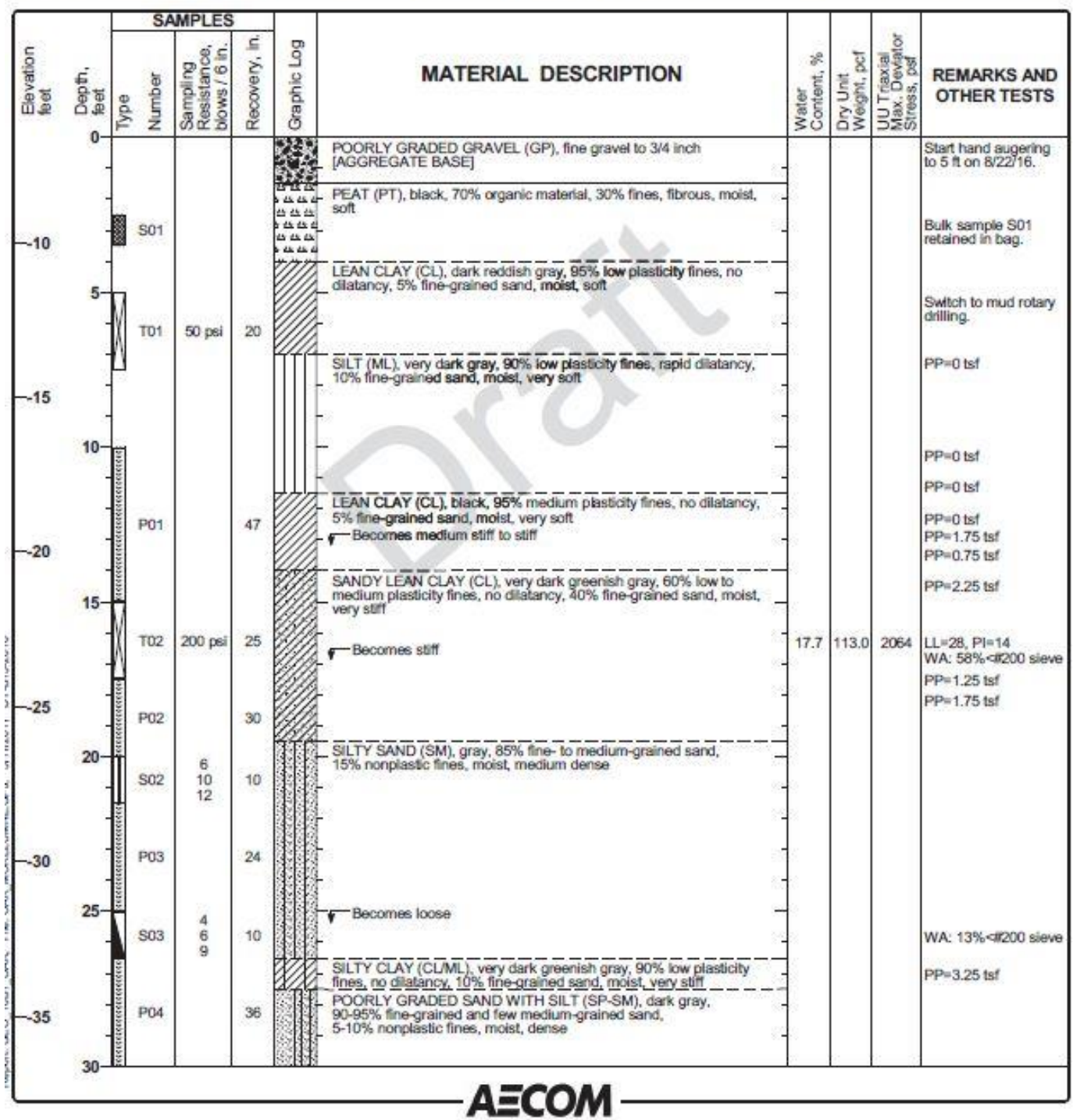

Figure C4. Boring log DT-B13-2016. Adapted from Phase 1 Geotechnical Exploration Program-Delta Tunnel Project (GDR) by AECOM, 2017. 


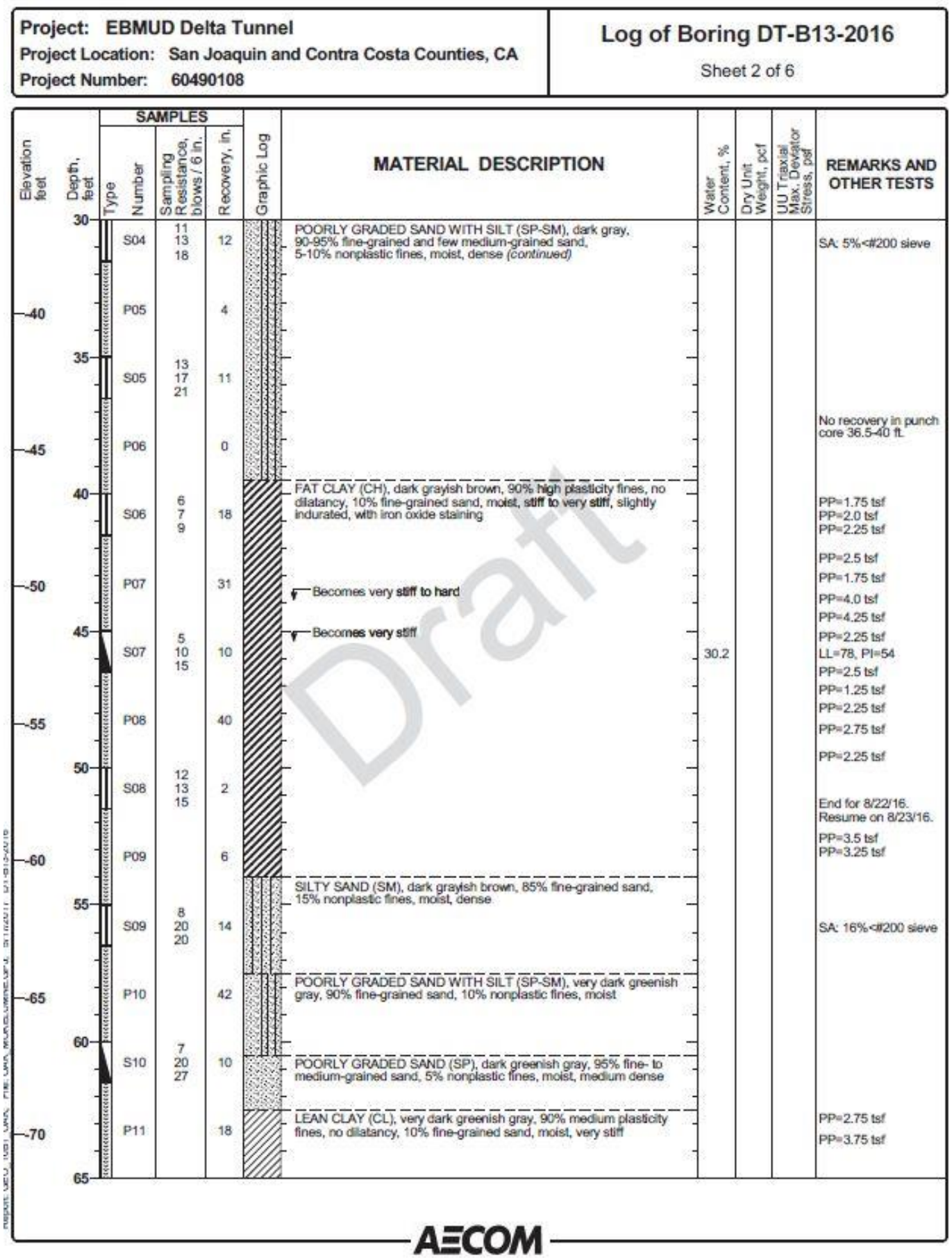

Figure C5. Boring log DT-B13-2016 continued. Adapted from Phase 1 Geotechnical Exploration Program-Delta Tunnel Project (GDR) by AECOM, 2017. 


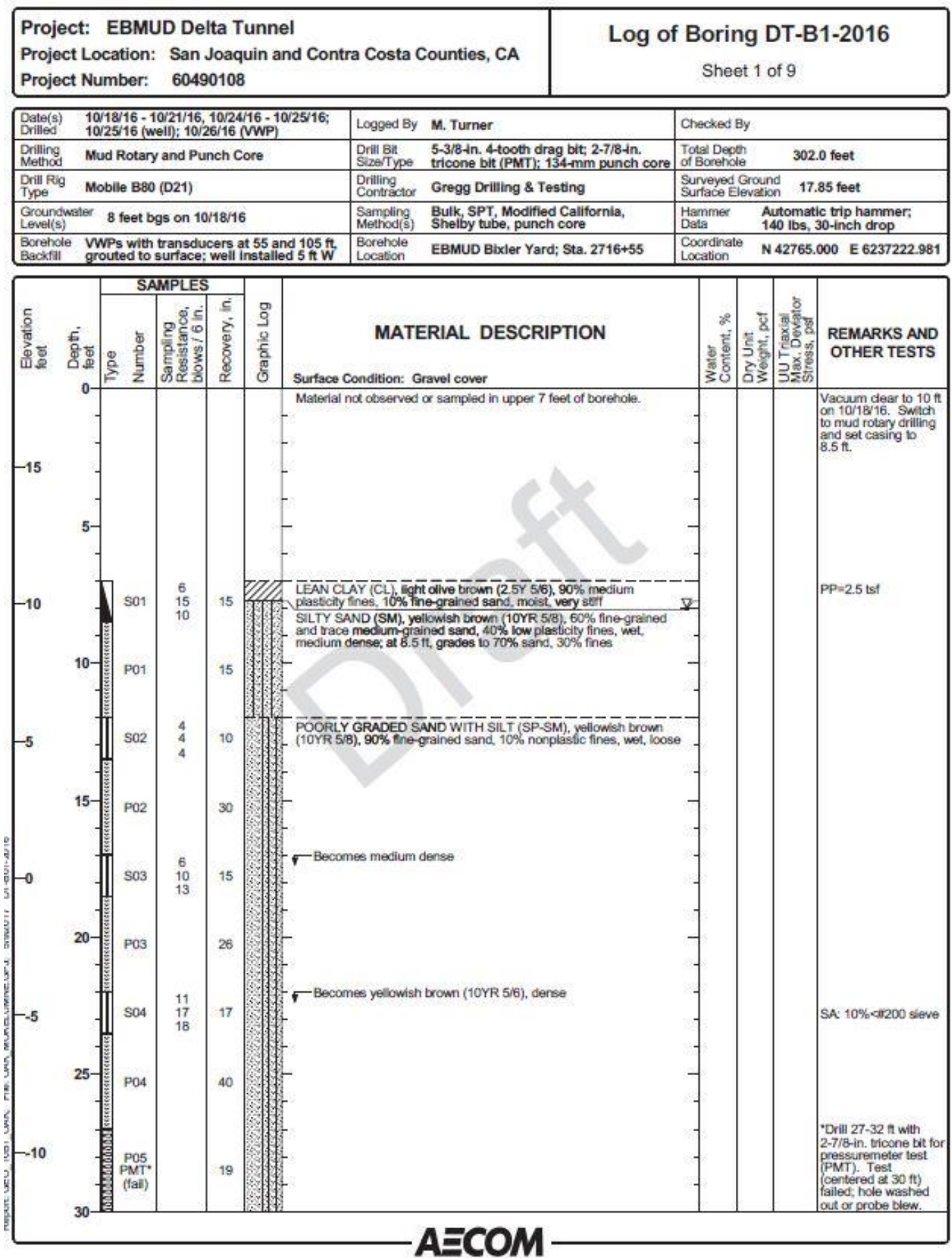

Figure C6. Boring log DT-B1-2016. Adapted from Phase 1 Geotechnical Exploration Program-Delta Tunnel Project (GDR) by AECOM, 2017. 


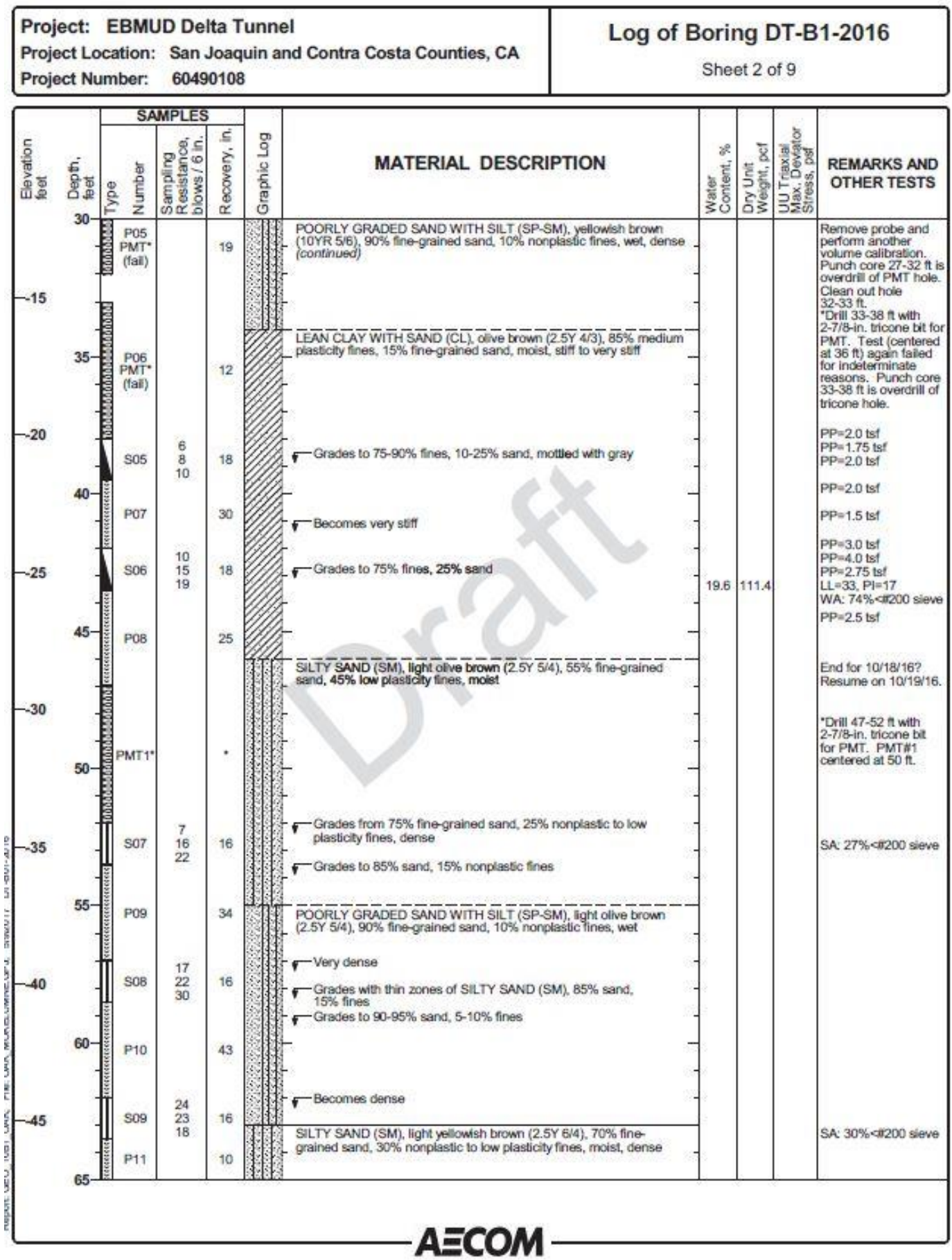

Figure C7. Boring log DT-B1-2016 continued. Adapted from Phase 1 Geotechnical Exploration Program-Delta Tunnel Project (GDR) by AECOM, 2017. 


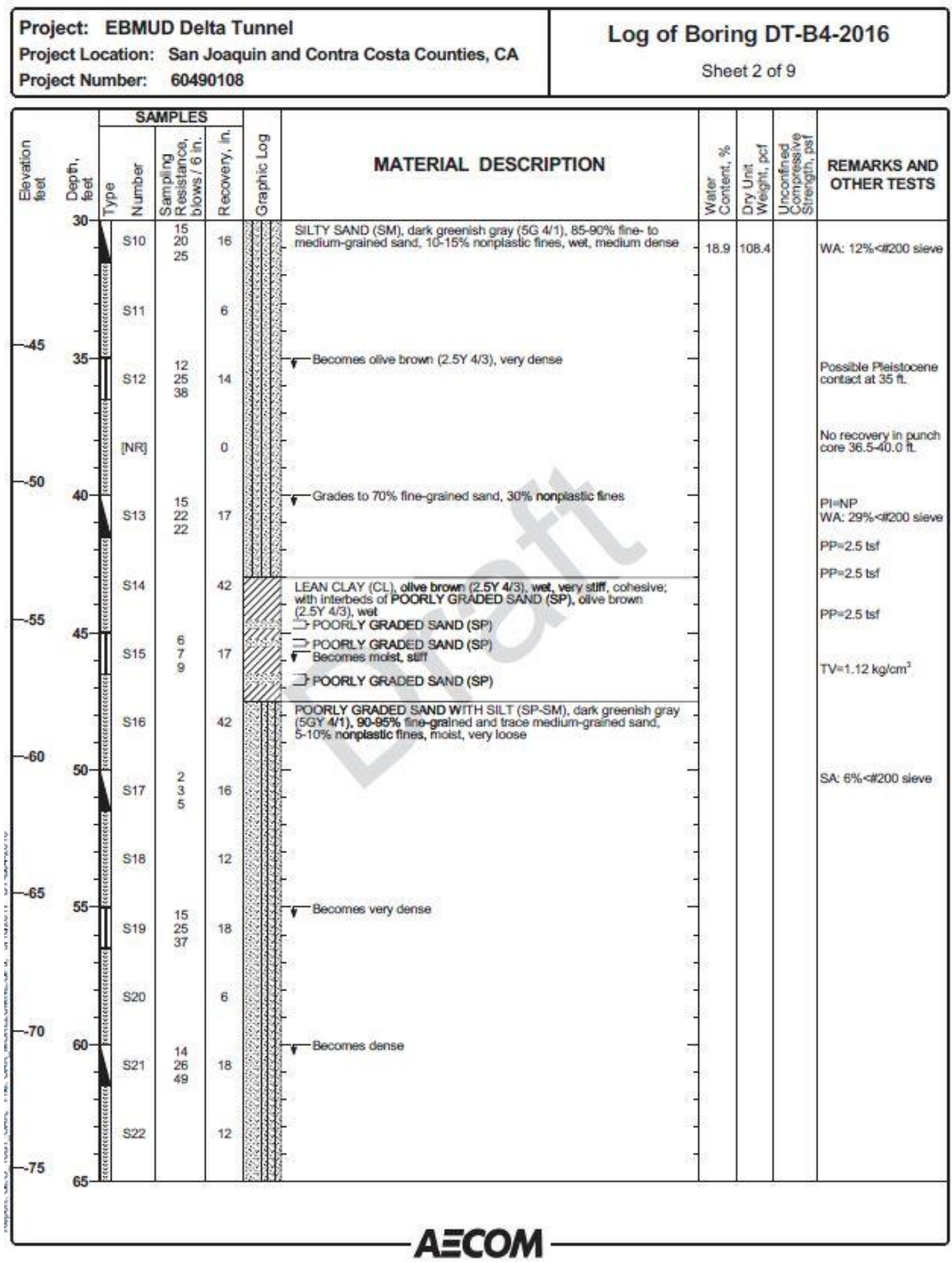

Figure C9. Boring log DT-B4-2016 continued. Adapted from Phase 1 Geotechnical Exploration Program-Delta Tunnel Project (GDR) by AECOM, 2017. 


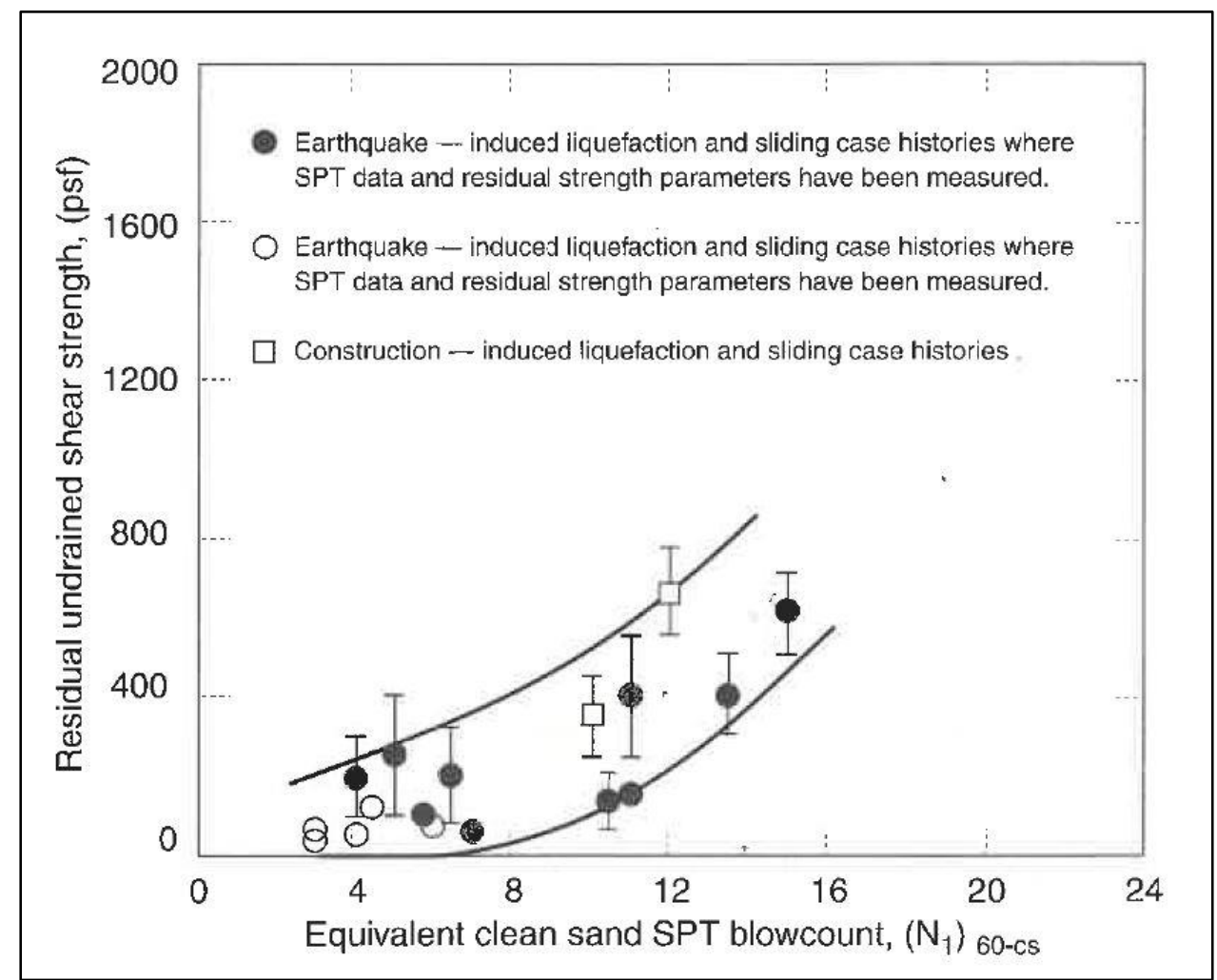

Figure C10. Relationship between residual strength and corrected SPT resistance. Reprinted from Geotechnical Earthquake Engineering (p.411), by S. L. Kramer, 1996.

Table C2

Fines Correction for Estimation of Residual Undrained Strength

\begin{tabular}{|c|c|}
\hline $\begin{array}{c}\text { Percent } \\
\text { Fines }\end{array}$ & $\begin{array}{c}\mathrm{N}_{\text {corr }} \\
\text { (blows/ft) }\end{array}$ \\
\hline 0 & 0 \\
\hline 10 & 1 \\
\hline 15 & - \\
\hline 20 & - \\
\hline 25 & 2 \\
\hline 30 & - \\
\hline 35 & - \\
\hline 50 & 4 \\
\hline 75 & 5 \\
\hline
\end{tabular}

Note. Adapted from Geotechnical Earthquake Engineering (p.411), by S. L. Kramer, 1996. 
Table C3

Parameters to Determine Corrected SPT N-Value

\begin{tabular}{|c|c|l|}
\hline Parameters & Value & \multicolumn{1}{|c|}{ Description } \\
\hline$N_{m}$ & 8 & from AECOM boring log \\
\hline$C_{N}$ & 1.1 & Depth correction factor \\
\hline$C_{E}$ & 1.13 & Hammer energy correction factor (ERi/60) \\
\hline$C_{B}$ & 1 & Borehole diameter correction factor \\
\hline$C_{R}$ & 0.95 & Rod length correction factor \\
\hline$C_{S}$ & 1.2 & $\begin{array}{l}\text { Correction factor for samplers with or without } \\
\text { liner }\end{array}$ \\
\hline
\end{tabular}

Note. Adapted from Caltrans Geotechnical Manual by the California Department of Transportation, 2014. 